STEVEN HOLL: A TRANSLATION OF PHENOMENOLOGICAL PHILOSOPHY INTO THE REALM OF ARCHITECTURE

\author{
A THESIS SUBMITTED TO \\ THE GRADUATE SCHOOL OF NATURAL AND APPLIED SCIENCES \\ OF \\ MIDDLE EAST TECHNICAL UNIVERSITY
}

BY

DERYA YORGANCIOĞLU

IN PARTIAL FULFILLMENT OF THE REQUIREMENTS FOR THE DEGREE OF MASTER OF ARCHITECTURE

IN

ARCHITECTURE

SEPTEMBER 2004 
Approval of the Graduate School of Natural and Applied Sciences

\section{Prof. Dr. Canan Özgen \\ Director}

I certify that this thesis satisfies all the requirements as a thesis for the degree of Master of Architecture.

\section{Assoc. Prof. Dr. Selahattin Önür Head of Department}

This is to certify that we have read this thesis and that in our opinion it is fully adequate, in scope and quality, as a thesis for the degree of Master of Architecture.

Asst. Prof. Dr. Cânâ Bilsel

Supervisor

Examining Committee Members

Assoc. Prof. Dr. Selahattin Önür (METU, ARCH)

Asst. Prof. Dr. Cânâ Bilsel (METU, ARCH)

Assoc. Prof. Dr. Gülsüm Baydar (BILKENT UNI.)

Assoc. Prof. Dr. Abdi Güzer (METU, ARCH)

Assoc. Prof. Dr. Ayşen Savaş (METU, ARCH) 
I hereby declare that all information in this document has been obtained and presented in accordance with academic rules and ethical conduct. I also declare that, as required by these rules and conduct, I have fully cited and referenced all material and results that not original to this work.

Name, Last name: Derya Yorgancioğlu

Signature : 


\title{
ABSTRACT \\ STEVEN HOLL: A TRANSLATION OF PHENOMENOLOGICAL PHILOSOPHY INTO THE REALM OF ARCHITECTURE
}

\author{
Yorgancioğlu, Derya \\ M. Arch, Department of Architecture \\ Supervisor: Asst. Prof. Dr. Cânâ Bilsel
}

September 2004, 133 pages

In this thesis it is aimed to develop a particular reading of Steven Holl's approach to architecture. It is claimed that in Holl's architecture there is a philosophical depth that embraces both his thinking on and making of architecture.

This thesis suggests that, the phenomenology of Maurice Merleau-Ponty, the French philosopher (1908-1961) is Steven Holl's main reference in achieving a philosophical depth in architecture. The thesis research focuses on understanding Holl's approach to architecture and its relation to Merleau-Ponty's phenomenological philosophy.

In the second part of the thesis, in aiming to unfold how the design process develops the study focused on the intellectual framework in Holl's architecture. Specific concepts that Holl dwells upon are examined in relation to their philosophical references. This section also comprises a focus on the architect as the subject of architectural practice.

In the third part, the phenomenological framework in the way Holl makes architecture is studied by examining how he relates building with site and situation; body to 
architectural space; body and architecture to time. This examination concludes with an inquiry in the haptic sensibility of the architect into articulating spaces and forms.

Lastly, the forth part involves a study on Holl's particular projects, through which it is aimed to examine the architectural embodiment of his phenomenological approach.

The thesis research in Steven Holl's architectural approach, which is held through his thinking on and making of architecture, opens up a field of study about the practice of an architect and the philosophical engagement of architecture.

Key Words: Architecture, Phenomenology, Maurice Merleau-Ponty, Idea, Phenomena, Concept, Intertwining, Anchoring, Situation, Body, Space. 


\title{
STEVEN HOLL: OLGUBİLIMSEL FELSEFENIN MIMARLIĞA TERCÜMESİ
}

\author{
Yorgancioğlu, Derya \\ Yüksek Lisans, Mimarlık Bölümü \\ Tez Yöneticisi: Yard. Doç. Dr. Cânâ Bilsel
}

Eylül 2004, 133 sayfa

$\mathrm{Bu}$ tez, Steven Holl'ün mimari yaklaşımını inceleyerek, onun mimarlığı düşünme ve yapma biçiminin altında yatan felsefi derinliği anlamayı amaçlamaktadır.

Araştırma, Fransız felsefeci Maurice Merleau-Ponty'nin (1908-1961) ortaya koyduğu olgubilim yaklaşımının Holl'ün mimarlığında geliştirdiği felsefi bir derinlik yakalamasının temel referansı olduğu savını ortaya koymaktadır. Steven Holl'ün ortaya koyduğu bu yaklaşım tezin temel araştırma konusunu oluşturmaktadır.

Tezin ikinci bölümünde, çalışma Holl’ün mimarlığının düşünsel çerçevesi üzerine yoğunlaşmaktadır. Böylece tasarım sürecinin ne şekilde geliştiği incelenerek ortaya konulmaya çalışılmaktadır. Mimarın üzerinde durduğu belli başlı kavramlar felsefi referansları 1şığında incelenmektedir. Bu bölümde ayrıca, mimarlık pratiğinin öznesi olarak mimar ele alınmaktadır.

Üçüncü bölümde Holl'ün mimarlığı yapma biçimi, tanımlanan olgubilimsel çerçevede incelenmekte, mimarın yapı, arazi ve durum (situation); beden ve mimari mekan; beden, mekan ve zaman arasında öngördüğü ilişki irdelenmektedir. Mimari mekan ve biçim yaratmada gözetilen deneyimsel duyarlılık (haptic sensibility) bu çalışma kapsamında ele 
alınmaktadır. Tezin dördüncü bölümünde Holl'ün mimari projeleri, ortaya koyduğu olgubilimsel çercevede incelenmektedir.

Steven Holl'ün mimarlığı düşünme ve yapma biçimi temel alınarak geliştirilen bu çalışma ile, bir mimarın mimarlığa yaklaşımı ve bu yaklaşımın felsefeyle ne şekilde ilişkilendiğine dair bir tartışma alanı sunulmaktadır.

Anahtar Kelimeler: Mimarlık, Olgubilim, Maurice Merleau-Ponty, Fikir, Olgu, Kavram, Deneyim, Karşıllıklı eşleme, Demir atma, Durum, Beden, Mekan. 
To My Family 


\section{ACKNOWLEDGEMENTS}

Foremost, I would like to express my gratitude for my supervisor Asst. Prof. Dr. Cânâ Bilsel for her valuable guidance and helpful criticisms during the thesis study. I would also like to thank her for her support, encouragement, motivation and the horizons she opened for my further studies.

I would also like to thank to Assoc. Prof. Dr. Abdi Güzer and Assoc. Prof. Dr. Ayşen Savaş for their recommendations and criticisms from the beginning of the study. I owe special thanks to Assoc. Prof. Dr. Selahattin Önür and Assoc. Prof. Dr. Gülsüm Baydar for their valuable evaluations in the critics of the final jury.

Finally, I offer sincere thanks to my family for their love, encouragement and support during the realization process of my thesis and during all my lifetime. 


\section{TABLE OF CONTENTS}

ABSTRACT

\section{CHAPTER}

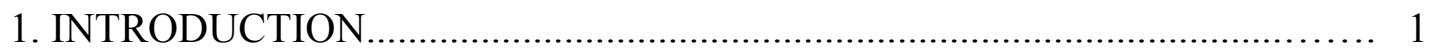

\section{THINKING ON ARCHITECTURE:}

STEVEN HOLL AND THE DESIGN PROCESS............................................. 7

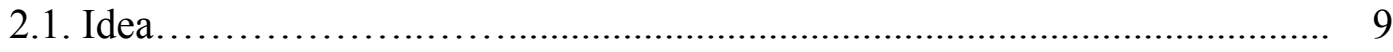

2.1.1. Idea in Holl's Architectural Design................................. 11

2.2. "Pre-Theoretical Ground" of Architecture.............................. 13

\subsection{Concept}

2.3.1. The Formation of a Concept out of an Idea........................ 15

2.3.2. "Limited Concept"............................................ 18

2.4. Architectural Thought............................................... 19

2.4.1. Intuition, Truth, Culture and Architectural Thought................ 20 
2.5. Architect as the Subject of the Architectural Design:

The Subjectivity of Steven Holl............................................ 24

2.5.1. Consciousness and Subjectivity ................................ 25

2.5.2. Lived Experiences and Subjectivity................................................. 26

2.5.3. Cultural Background of the Architect................................................ 27

2.5.4. Intersubjectivity of the Architect................................. 28

\section{THE MAKING OF ARCHITECTURE:}

\section{PHENOMENOLOGY OF THE CREATION AND EXPERIENCE OF}

\section{ARCHITECTURAL WORK}

3.1. The "Intertwining" of Idea and Phenomena through Architectural Practice

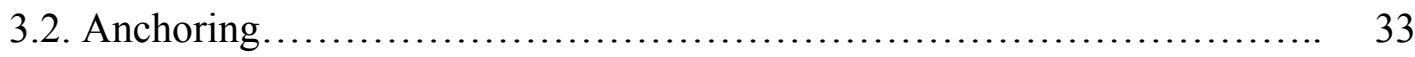

3.2.1 Building, Site and Situation...................................... 34

3.2.2. The "Metaphysical Fusion" of the Building, Site and Situation...... 39

3.2.3. The Meaning in Situation...................................... 43

3.2.4. "Lived space" in the Anchoring of Architecture.................... 47

3.3. The "Intertwining" of the Body and the World.......................... 50

3.3.1. A Philosophical Conception of Space:

Merleau-Ponty and the Phenomenology of Space................... 52

3.3.2. Body and Space in Steven Holl's Architecture..................... 54

3.3.2.1. The Poetic Intensity in the "Lived Space"................. 56

3.3.2.2. Motility of the Body in Space.............................. 61

3.3.2.3. "Parallax"............................................. 65 
3.3.3. Space-time Couple in Steven Holl's Architecture

3.3.3.1. The Spatiality of Time................................ 67

3.3.3.2. The Subjective Interpretation of Time: "Duration".......... 68

3.3.4. "Haptic" Sensibility in Steven Holl's Arcitecture.................... 70

3.3.4.1. "Chemistry of Matter" and Haptic Psychology.............. 76

3.3.4.2. Haptic Sensibility as a Resistance to the Loss of Experiential

Depth................................................ 79

4. IN SEARCH OF THE ARCHITECTURAL EMBODIMENT THROUGH A

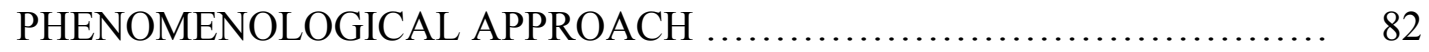

4.1. From Concept to Architectural Form............................... 83

4.2. The Conceptual and Experiential Anchoring of the Building into the Site and

the Situation ...................................................... 102

4.3. Body, Movement and the Architectural Space........................... 108

4.4. The Phenomena of Architecture: A Haptic Field .......................... 113

4.4.1. 'Light' as a Structural Material................................. 118

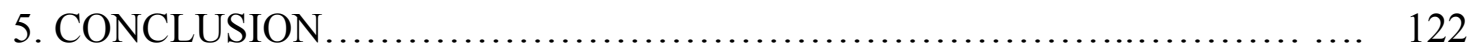

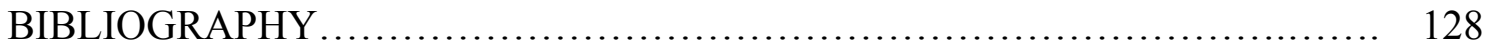




\section{LIST OF FIGURES}

\section{FIGURES}

2.1. Sketch of the "Right Hand Rule" concept for Bellevue Art Museum, Washington, 1997-2001.

Source: Holl, Steven 2000, Parallax, New York: Princeton Architectural Press,

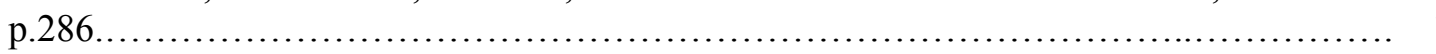

2.2. Watercolor sketches of interior space for Bellevue Art Museum.

Source: El croquis, revised and extended edition (including issues of 78, 93, 108), Mexico:

Arquitectos Publishing, p.52 ...................................................... 2

2.3. Watercolor sketches of interior space for Bellevue Art Museum.

Source: El croquis, revised and extended edition (including issues of 78, 93, 108), Mexico:

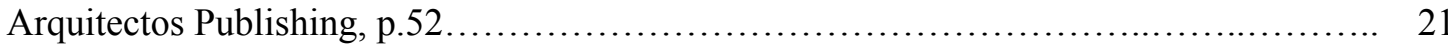

3.1. Watercolor sketch for Museum of Human Evolution, Burgos, Spain, 2000-

Source: Frampton, Kenneth, 2002, Steven Holl Architect, Milano: Electa Architecture,

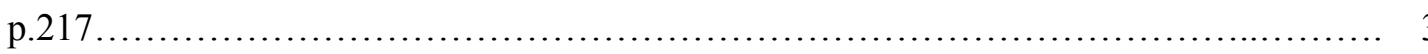

3.2. The metaphysics of place: Helsinki Museum of Contemporary Art, 1993-98.

Source: Kiasma, 1998, Helsinki: Art Print, p.46

3.3. The metaphysics of place: Helsinki Museum of Contemporary Art, 1993-98.

Source: Kiasma, 1998, Helsinki: Art Print, p.56.

3.4. Building fuses through situation: Y House, New York, 1997-99.

Source: Holl, Steven 2000, Parallax, New York: Princeton Architectural Press,

p. 65 . 
3. 5. Architectural space as lived space: Makuhari Housing, Japan, 1992-96

Source: Holl, Steven 2000, Parallax, New York: Princeton Architectural Press,

p.224.

3.6. Poetic spatiality: Helsinki Museum of Contemporary Art, 1993-98

Source: Holl, Steven 2000, Parallax, New York: Princeton Architectural Press,

p.50.

3.7. Poetic spatiality: Helsinki Museum of Contemporary Art, 1993-98

Source: Kiasma, 1998, Helsinki: Art Print, p.54

3.8. Poetic spatiality: Helsinki Museum of Contemporary Art, 1993-98

Source: Kiasma, 1998, Helsinki: Art Print, p.54.

3.9. House as "a home for the soul": Stretto House, Dallas, 1990-92

Source: http://www.stevenholl.com.htm (August 10, 2004)....

3.10. House as "a home for the soul": Stretto House, Dallas, 1990-92

Source: Frampton, Kenneth, 2002, Steven Holl Architect, Milano: Electa Architecture, p.366......

3.11. Looking for spatial perceptions of moving body: Helsinki Museum of Contemporary Art, 1993-98

Source: El croquis, revised and extended edition (including issues of 78, 93, 108), Mexico: Arquitectos Publishing, p.251

3.12. Looking for spatial perceptions of moving body: Helsinki Museum of Contemporary Art, 1993-98

Source: El croquis, revised and extended edition (including issues of 78, 93, 108), Mexico: Arquitectos Publishing, p.251.

3.13. Overlapping perspectives of moving body in space: Bellevue Art Museum, Washington, 1997-2001. 
Source: Frampton, Kenneth, 2002, Steven Holl Architect, Milano: Electa Architecture, p. 81

3.14. Overlapping perspectives of moving body in space: Bellevue Art Museum, Washington, 1997-2001.

Source: Idea and Phenomena, 2002, Architekturzentrum Wien (ed.), Switzerland: Lars Müller

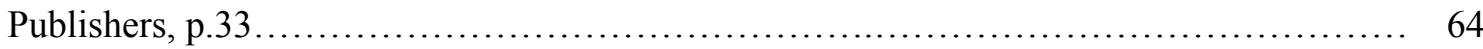

3.15. Spatial Parallax: Museum of Human Evolution, Burgos, Spain, 2000-

Source: El croquis, revised and extended edition (including issues of 78, 93, 108), Mexico:

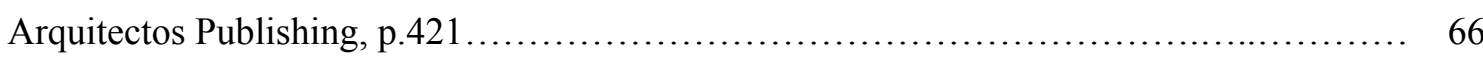

3.16. Spatial Parallax: Museum of Human Evolution, Burgos, Spain, 2000-

Source: El croquis, revised and extended edition (including issues of 78, 93, 108), Mexico:

Arquitectos Publishing, p.425....................................................... 66

3. 17. A haptic field of architectural phenomena: Addition to the Cranbrook Institute of Science, Michigan, 1992-98.

Source: Idea and Phenomena, 2002, Architekturzentrum Wien (ed.), Switzerland: Lars Müller

Publishers, p.33 ............................................................... 72

3.18. Tactile phenomena of architectural space: Chapel of St. Ignatus, Seattle, 1994-97. Source: Idea and Phenomena, 2002, Architekturzentrum Wien (ed.), Switzerland: Lars Müller

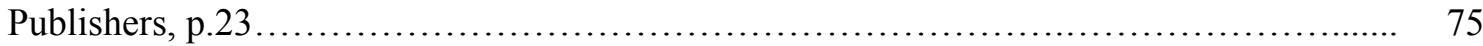

4.1. The concept sketch of "intertwining": The concept sketch of Helsinki Museum of Contemporary Art, 1993-98.

Source: Holl, Steven 2000, Parallax, New York: Princeton Architectural Press, p.39....... 84

4.2. "Lines of force"in the museum design.

Source: Holl, Steven 2000, Parallax, New York: Princeton Architectural Press, p.46......... 84

4.3. Site Plan: Helsinki Museum of Contemporary Art, 1993-98. 
Source: Holl, Steven, 1998 (first published in 1996), Intertwining, New York: Princeton

Architectural Press, p.89.

4.4. Photomontage of model in site.

Source: Holl, Steven, 1998 (first published in 1996), Intertwining, New York: Princeton Architectural Press, p.91

4.5. Entrance façade of the museum.

Source: Frampton, Kenneth, 2002, Steven Holl Architect, Milano: Electa Architecture, p.232. 86

4.6. Looking for the architectonic embodiment of the "chiasm": Helsinki Museum of Contemporary Art, 1993-98.

Source: El croquis, revised and extended edition (including issues of 78, 93, 108), Mexico:

Arquitectos Publishing, p.276.

4.7. Looking for the architectonic embodiment of the "chiasm": Helsinki Museum of Contemporary Art, 1993-98.

Source: Kiasma, 1998, Helsinki: Art Print, p.76.

4.8. Concept sketch of "Seven Bottles of Light in a Stone Box": The Chapel of St. Ignatus, Seattle, 1994-97.

Source: Holl, Steven, 1998 (first published in 1996), Intertwining, New York: Princeton Architectural Press, p.158.

4.9. Watercolor sketches of the chapel.

Source: El croquis, revised and extended edition (including issues of 78, 93, 108), Mexico:

Arquitectos Publishing, p.280.

4.10. Watercolor sketches of the chapel.

Source: El croquis, revised and extended edition (including issues of 78, 93, 108), Mexico: Arquitectos Publishing, p.280. 
4.11. The "Altar": The Chapel of St. Ignatus, Seattle, 1994-97.

Source: El croquis, revised and extended edition (including issues of 78, 93, 108), Mexico:

Arquitectos Publishing, p.299.

4.12. The irregular roof tectonic with "vaults of light".

Source: Frampton, Kenneth, 2002, Steven Holl Architect, Milano: Electa Architecture, p.302

4.13. Light reflections over the "thinking pool": The Chapel of St. Ignatus, Seattle, 199497.

Source: Holl, Steven, 1998 (first published in 1996), Intertwining, New York: Princeton

Architectural Press, p.162

4.14. "Urban Porosity" as the central concept of the design: Simmons Hall, Massachusetts, 1999-2002.

Source: Holl, Steven 2000, Parallax, New York: Princeton Architectural Press, p.309........

92

4.15. "Urban Porosity" as the central concept of the design: Simmons Hall, Massachusetts, 1999-2002.

Source: Holl, Steven 2000, Parallax, New York: Princeton Architectural Press, p.309......

92

4.16. The metaphor of sponge as a tool for image making: Simmons Hall, Massachusetts, 1999-2002.

Source: Holl, Steven 2000, Parallax, New York: Princeton Architectural Press, p.304...... 93

4.17. The metaphor of sponge as a tool for image making: Simmons Hall, Massachusetts, 1999-2002.

Source: Holl, Steven 2000, Parallax, New York: Princeton Architectural Press, p.304_..... 93

4.18. Sponge painted plans generating horizontal porosity: Simmons Hall, Massachusetts, 1999-2002.

Source: Amelar, Sarah, Architectural Record vol.191 no.5, 2003,p.211_............... 94

4.19. Sponge painted plans generating horizontal porosity: Simmons Hall, Massachusetts, 1999-2002. 
Source: El croquis, revised and extended edition (including issues of 78, 93, 108), Mexico:

Arquitectos Publishing, p.524.

4.20. Organic "Lungs” generating vertical porosity: Simmons Hall, Massachusetts, 19992002.

Source: El croquis, revised and extended edition (including issues of 78, 93, 108), Mexico:

Arquitectos Publishing, p.518

4.21.The location of Simmons Hall on the MIT Campus.

Source: "Redefining the University," April 2003, Domus vol. 858, p.43.................. 96

4.22.Knut Hamsun Museum, Norway, 1996/98-

Source: Frampton, Kenneth, 2002, Steven Holl Architect, Milano: Electa Architecture, p.296.

4.23. Concept sketch as "building: a body- battleground of invisible forces": Knut

Hamsun Museum, Norway, 1996/98-

Source: El croquis, revised and extended edition (including issues of 78, 93, 108), Mexico:

Arquitectos Publishing, p.310.

98

4.24. Watercolor sketches of the Knut Hamsun Museum.

Source: Frampton, Kenneth, 2002, Steven Holl Architect, Milano: Electa Architecture, p.299.

4.25.Watercolor sketches of the Knut Hamsun Museum.

Source: Frampton, Kenneth, 2002, Steven Holl Architect, Milano: Electa Architecture, p.298

4.26. Site plan: Museum of Human Evolution, Burgos, Spain, 2000-

Source: Frampton, Kenneth, 2002, Steven Holl Architect, Milano: Electa Architecture, p.216. 
4.27. Photomontage of model in the site: Museum of Human Evolution, Burgos, Spain, 2000-

Source: Idea and Phenomena, 2002, Architekturzentrum Wien (ed.), Switzerland: Lars Müller Publishers,

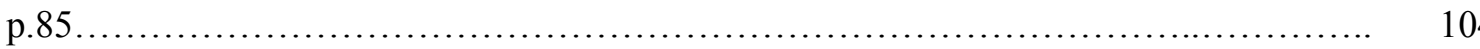

4.28. Studying with overlapping contrast: Museum of Human Evolution, Burgos, Spain, $2000-$

Source: El croquis, revised and extended edition (including issues of 78, 93, 108), Mexico:

Arquitectos Publishing, p.418

105

4.29. "Cave" metaphor as a design vehicle: Museum of Human Evolution, Burgos, Spain, $2000-$

Source: El croquis, revised and extended edition (including issues of 78, 93, 108), Mexico:

Arquitectos Publishing, p.420

106

4.30. "Cave" metaphor as a design vehicle: Museum of Human Evolution, Burgos, Spain, 2000-

Source: El croquis, revised and extended edition (including issues of 78, 93, 108), Mexico:

Arquitectos Publishing, p.420

106

4.31. "Chromatic Space" acting as an Urban Mirror: Museum of Human Evolution, Burgos, Spain, 2000-

Source: El croquis, revised and extended edition (including issues of 78, 93, 108), Mexico:

Arquitectos Publishing, p.423

4.32. "Chromatic Space" acting as an Urban Mirror: Museum of Human Evolution, Burgos, Spain, 2000-

Source: El croquis, revised and extended edition (including issues of 78, 93, 108), Mexico:

Arquitectos Publishing, p.423

107 
4.33. "Chromatic Space" acting as an Urban Mirror: Museum of Human Evolution, Burgos, Spain, 2000-

Source: El croquis, revised and extended edition (including issues of 78, 93, 108), Mexico: Arquitectos Publishing, p.423.

4.34. The fluid spatiality presented through circulation elements: Helsinki Museum of Contemporary Art, 1993-98.

Source: Frampton, Kenneth, 2002, Steven Holl Architect, Milano: Electa Architecture, p.242

4.35. The fluid spatiality presented through circulation elements: Helsinki Museum of Contemporary Art, 1993-98.

Source: Frampton, Kenneth, 2002, Steven Holl Architect, Milano: Electa Architecture, p.242

4.36. Space as a neutral ground for exhibition: Helsinki Museum of Contemporary Art, 1993-98.

Source: El croquis, revised and extended edition (including issues of 78, 93, 108), Mexico: Arquitectos Publishing, p.273

4.37. Exhibition galleries: Helsinki Museum of Contemporary Art, 1993-98.

Source: El croquis, revised and extended edition (including issues of 78, 93, 108), Mexico:

Arquitectos Publishing, p.268.

4.38. Exhibition galleries: Helsinki Museum of Contemporary Art, 1993-98.

Source: El croquis, revised and extended edition (including issues of 78, 93, 108), Mexico:

Arquitectos Publishing,p.271

4.39. Effects of light create spatial fluidity: Simmons Hall, Massachusetts, 1999-2002.

Source: http://web.mit.edu/evolving/projects/simmons/index.html

(August 5, 2004) 
4.40. Effects of light create spatial fluidity: Simmons Hall, Massachusetts, 1999-2002. Source: http://web.mit.edu/evolving/projects/simmons/images/full/000886.jpg

(August 5, 2004)

4.41. 'Spatial dynamism' through organic forms: Simmons Hall, Massachusetts, 19992002.

Source: Amelar, Sarah, Architectural Record vol.191 no.5, 2003,p.208.

4.42. 'Spatial dynamism' through organic forms: Simmons Hall, Massachusetts, 19992002.

Source: Amelar, Sarah, Architectural Record vol.191 no.5, 2003,p.209.

4.43. The architectonic effect of the Chapel of St. Ignatus, Seattle, 1995-97.

Source: Frampton, Kenneth, 2002, Steven Holl Architect, Milano: Electa Architecture, p.305

4.44. The architectonic effect of the Chapel of St. Ignatus, Seattle, 1995-97.

Source: El croquis, revised and extended edition (including issues of 78, 93, 108), Mexico:

Arquitectos Publishing, p.305.

4.45. The architectonic effect of the Chapel of St. Ignatus, Seattle, 1995-97.

Source: Frampton, Kenneth, 2002, Steven Holl Architect, Milano: Electa Architecture, p.304

4.46. "Pews" inside the chapel.

Source: Frampton, Kenneth, 2002, Steven Holl Architect, Milano: Electa Architecture, p.314

4.47. Sand-blasted lamp in the Chapel.

Source: Holl, Steven 2000, Parallax, New York: Princeton Architectural Press, p.80.......

4.48. The oil-rubbed, carved Alaskan cedar door: The Chapel of St. Ignatus, Seattle, Washington, 1994-97.

Source: Frampton, Kenneth, 2002, Steven Holl Architect, Milano: Electa Architecture, p.310 
4.49. The oil-rubbed, carved Alaskan cedar door: The Chapel of St. Ignatus, Seattle, Washington, 1994-97.

Source: Frampton, Kenneth, 2002, Steven Holl Architect, Milano: Electa Architecture, p.311

4.50. Light as a space-defining element in the Chapel of St. Ignatus.

Source: Idea and Phenomena, 2002, Architekturzentrum Wien (ed.), Switzerland: Lars Müller

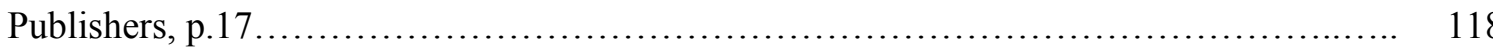

4.51. Light as a space-defining element in the Chapel of St. Ignatus.

Source: Holl, Steven 2000, Parallax, New York: Princeton Architectural Press, p.142.......

4.52. Light as a space-defining element in the Chapel of St. Ignatus.

Source: Holl, Steven 2000, Parallax, New York: Princeton Architectural Press, p.156........

4.53. Light as a space-defining element in the Chapel of St. Ignatus

Source: Idea and Phenomena, 2002, Architekturzentrum Wien (ed.), Switzerland: Lars Müller

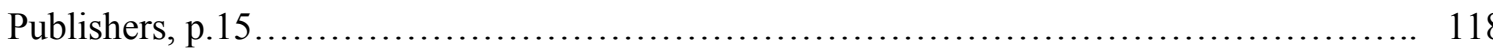

4.54."Light Laboratory" in Addition to Cranbrook Institute of Science, Michigan, 199298.

Source: Idea and Phenomena, 2002, Architekturzentrum Wien (ed.), Switzerland: Lars Müller

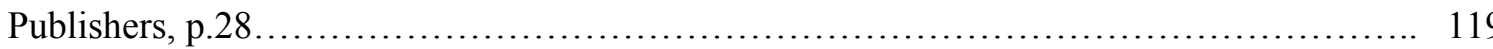

4.55. "Light Laboratory" in Addition to Cranbrook Institute of Science, Michigan, 199298.

Source: Idea and Phenomena, 2002, Architekturzentrum Wien (ed.), Switzerland: Lars Müller

Publishers, p.32 .............................................................. 119

4.56. "Light Laboratory" in Addition to Cranbrook Institute of Science, Michigan, 199298. 
Source: Idea and Phenomena, 2002, Architekturzentrum Wien (ed.), Switzerland: Lars Müller

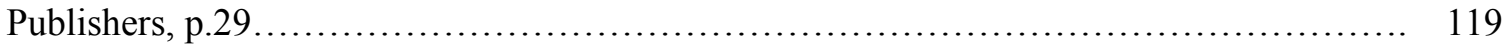

4.58. Color reflections on the De Single Canal: Sarphatistraat Offices, Amsterdam, 19962000.

Source: Frampton, Kenneth, 2002, Steven Holl Architect, Milano: Electa Architecture, p.291 


\section{CHAPTER 1}

\section{INTRODUCTION}

Steven Holl has a distinct position in today's architectural realm with the intellectual and phenomenal intensity of his work. The tectonic properties of his buildings, his use of materials, texture, color and light can be considered as the qualities through which Holl's architecture can be distinguished.

Architectural critics have met the architecture of Steven Holl and his contribution to architectural discourse with a growing recognition. Yet, his work is often criticized or categorized within different perspectives.

In his various essays on the work of Steven Holl, Kenneth Frampton, architectural historian and critic, points out the architect's emphasis on the site, typology, local and cultural values, which for him leads to align Holl's approach with Critical Regionalism. Frampton stresses on Holl's focus on the context wherein “... landscape, type and building method are synthesized into a new and challenging whole." "In achieving this, Holl approaches to the critical regionalist goal of re-interpreting the context; yet, avoiding merely formal or visual replication. According to Frampton, Holl achieves this by maintaining "a responsibility to challenge the morphology of a site as to harmonize with its apparent attributes.” "2 From another perspective, Alejandro Zaero Polo, architect, states that Holl's strive to find the value of architecture in culture and history of the site brings him close to Post-modernism. ${ }^{3}$ Holl is inspired by the meaning of the site that is generated within cultural or historical framework. In her essay entitled "El Yordamıla Mimarlık: Paralaks, bilinç, içgüdü ve Steven Holl” (Intuitive Architecture: Parallax,

\footnotetext{
${ }^{1}$ Kenneth Frampton, 1989, “On the Architecture of Steven Holl," introduction in Anchoring, New York: Princeton Architectural Press, p.6.

${ }^{2}$ Kenneth Frampton, 2002, Steven Holl Architect, Milano: Electa Architecture, p.11.

${ }^{3}$ Alejandro Zaera Polo, 2003, "A Conversation with Steven Holl," in El croquis, revised and extended edition (first published in El croquis issue 78 January/February 1996), Mexico: Arquitectos Publishing, pp. 16.
} 
consciousness, intuition and Steven Holl), Ayşen Savaş, architect, critically emphasizes that Steven Holl puts forward an "intuitively" developed approach to architecture that inevitably leads to a naïve practice. ${ }^{4}$ In his article "Steven Holl. Kavramsal Mimarlı̆gn Yeni Ürünleri" (Steven Holl. New Products of Conceptual Architecture), Uğur Tanyeli, architectural historian and critic, pointing out the conceptual framework of Holl's designs argues that the concept constructed by the architect during the design process is artificially attributed to the architectural form. ${ }^{5}$ Therefore, for Tanyeli, the architect "arbitrarily" relates a design concept with the building. ${ }^{6}$

Aside from all criticisms or categorizations related to the work of Steven Holl, this thesis proposes that there exists a philosophical depth in his architecture. The significance of Holl's architecture is revealed through the philosophical depth that interplays within his thinking and making of architecture.

This thesis brings forth an attempt to understand the philosophical depth of Steven Holl's approach to architecture in order to explore his architectural position. The objective of this research is constructed on the basis of two main hypotheses:

The philosophical background of Holl's architecture is mainly based on the phenomenology of Maurice Merleau-Ponty, the French philosopher (1908-1961). Holl gives clues about how the Merleau-Pontian phenomenology inspires him to re-think on architecture. ${ }^{7}$ The architect concentrates on Merleau-Ponty's phenomenological philosophy on which he develops his own way of architectural thinking. In re-interpreting the philosophical concepts of Merleau-Ponty's phenomenology, the architect transforms them into architectural concepts. In doing this, it can be stated that Steven Holl brings forth a translation of philosophical concepts into the realm of architecture.

\footnotetext{
${ }^{4}$ Ayşen Savaş, May 1995, "El Yordamıyla Mimarlık: Paralaks, bilinç, içgüdü ve Steven Holl” (Intuitive Architecture: Parallax, consciousness, intuition and Steven Holl) in Arredamento Dekorasyon vol.5 no.70, p. 77. Savaş teaches as the Middle East Technical University as Assoc. Prof. Dr.

${ }^{5}$ Uğur Tanyeli, February 2002, "Steven Holl. Kavramsal Mimarlığın Yeni Ürünleri”" (Steven Holl. New Products of Conceptual Architecture) in Arredamento Dekorasyon vol.2, p. 40.

${ }^{6}$ Ibid.
} 
Secondly, Holl's making of architecture develops around the intellectual framework in which he connects phenomenology to architecture. The way he makes architecture becomes a field of practice where phenomenal aspects are elaborated to achieve a design concept. The "intertwining of idea and phenomena," as he calls it, designates this phenomenological approach that characterizes his architecture. ${ }^{8}$

This thesis suggests a field of research in the processes of architectural design and its articulation through the conceptual realm that Steven Holl puts forward. It is aimed to understand the interaction between his thinking and making of architecture that develops on the basis of the particular philosophical depth he arrives at. It is proposed to open up a perspective for exploring how philosophy interplays in Holl's practice of architecture.

The scope of the thesis research incorporates three main subjects, which are Holl's thinking of architecture, his making of architecture and the analysis of his particular projects through which the relationship between these two aspects of architectural practice will be studied.

The second chapter of the thesis is concentrated on Steven Holl's design process in order to understand the intellectual framework of his architecture. It is aimed to explore the philosophical approach of the architect that lies beneath the phenomenal and experiential particularity of his architecture. The chapter begins with the examination of the main concepts that the architect introduces into the realm of architecture. This examination will be carried through investigating the philosophical references of these concepts in order to understand the overall philosophical framework of Holl's architecture. The last part of the second chapter is focused on the subjectivity of the architect. The intention is to discuss the dynamics that interplay within the intellectual background of the architect and the role subjectivity takes in his thinking of architecture.

\footnotetext{
${ }^{7}$ In particular; Steven Holl, 2000, Parallax, New York: Princeton Architectural Press, p. 302.

${ }^{8}$ Op. cit. Holl, S., 1989, p. 10.
} 
Steven Holl puts forward experimental designs that present a characteristic articulation of spaces, forms and details. In Holl's architectural practice we come across a particular way of making architecture, in which the conceptual base of his work extends to a phenomenal intensity through built forms. His making of architecture reveals its particularity through the experiential quality of his buildings. The third chapter will investigate the phenomenological framework of Holl's architectural practice by discussing how "intertwining idea and phenomena" generates the way he articulates spaces and forms. The relationship between building, site and situation, which is discussed under the title of "anchoring," and his search for the architectural meaning generated out of the situation, will be elaborated in the continuation of the third chapter. The last part of the third chapter will examine the primacy of body, motility and time in Holl's phenomenological understanding of architectural space. His concern with materiality and hapticity in architecture will be the subject of the last part of the third chapter.

In the light of the research that will be conducted throughout the second and third chapters, in the forth chapter Steven Holl's specific projects will be examined. This examination will be carried through a parallel reading between the architectural concepts he has translated from philosophy into the realm of architecture and their geometric, spatial and material expressions. By doing this, it is aimed to explore in which way phenomenology provides a common ground for Holl's thinking and making of architecture. However, the issue of how successfully his buildings exhibit the design concept he begins with is out of the objective of the examination. Instead, the transformation process through which the spatial, material and experiential embodiment of a concept is achieved, constitute the principle object of exploration.

In his major book Phenomenology of Perception, Merleau-Ponty brings forth phenomenological arguments in which he examines human beings' existence. ${ }^{9} \mathrm{He}$ aims to explore the actual nature of our relationship to objects, other people, and the entire

\footnotetext{
${ }^{9}$ Maurice Merleau-Ponty, 1962 (first published in 1945), Phenomenology of Perception, trans. by Colin Smith, London: Routledge and Kegan.
} 
world, which according to the philosopher, depends on our perceptual experiences. For the philosopher, perception is the fundamental act that enables human beings to inhabit space and time. ${ }^{10}$ The essence of being resides in our ability to sense and experience the physical world around us. To perceive enables human beings to gain access into the world: then, as the philosopher states, the world becomes "what we perceive."11

In connecting the essence of being with sensations and experiences, Merleau-Ponty locates bodily presence at the core of his philosophy. He puts emphasis on the unity of body in which physical and spiritual existences are incorporated. It is the body that exists in the world, senses, conceives and is aware of his/her own existence as subject: "a subject destined to the world". ${ }^{12}$ In other words, Merleau-Ponty puts emphasis on the embodied subjectivity that is signified through his use of the term "body-subject."

The body-subject inhabits space and time. It is not possible to understand human existence independently of culture, history, or society, since there is a perceptual situatedness of the body-subject into the world. "Being-in-the-world" manifests being situated wherein our own and the world's presence acquires meaning.

Merleau-Ponty develops his phenomenological arguments around human beings' corporeal experiences as the fundamental ground of existence. In bringing forth an everlasting process of inquiry, he acquires a distinct position in the philosophical realm; Merleau-Ponty avoids proposing determinate or complete formula. On the contrary, he introduces an interrogating and open-ended perspective, which is meant to be the real goal of phenomenology.

Phenomenology has always been a matter of interest for the architectural realm. The considerable influence of the Heideggerian phenomenology on the realm of architecture should not be disregarded. However, at this point it is important to stress on the distinct philosophical position of Martin Heidegger and its reflections on the work of Christian

\footnotetext{
${ }^{10}$ Ibid. pp. x-xi.

${ }^{11}$ Ibid. p. xvi.

${ }^{12}$ Ibid. p. xi.
} 
Norberg-Schulz in order to better understand and locate Steven Holl's architectural standpoint.

Heidegger grounds his philosophy on the concept of "dwelling" as the means human beings inhabit space and time. The philosopher situates human dwelling into existential roots; man dwells with reference to the inherent, existential meaning of space, which makes it a place. Through a metaphysical perspective, Heidegger searches for the preexisting meaning of existence whose foundation is the Being. As an architectural theorist, Norberg-Schulz focuses on the notion of place in architecture with reference to Heidegger's phenomenological standpoint. Searching for the existential meaning of place, architecture, for Norberg-Schulz, is the fundamental medium in which this existential meaning comes into presence through the materiality of a built form.

The distinction between the phenomenological perspectives of Steven Holl and NorbergSchulz will be elaborated further in the thesis. This elaboration will be carried parallel to a focus on the distinction between the phenomenological standpoints of Merleau-Ponty and Heidegger in the philosophical realm.

For Steven Holl, the phenomenology in architecture resides in the experiential potential of architecture, independently of a pre-existing inherent meaning. Accordingly, we come across a relation between his architecture and the phenomenological philosophy of Merleau-Ponty. In this thesis the examination of this relation starts with raising some significant questions:

What is the fundamental challenge of Merleau-Ponty's phenomenology for Steven Holl, as an architect? How does his philosophical concern influence Holl's understanding of architecture? In which way does phenomenology contribute to his architectural practice? The content of the thesis research will be developed on the basis of investigating the issues introduced above, which will help to understand the philosophical depth of Steven Holl's architecture. 


\section{CHAPTER 2}

\section{THINKING ON ARCHITECTURE: STEVEN HOLL AND THE DESIGN PROCESS}

The processes of thinking and making can be stated as two interdependent and complementary practices of architecture. While thinking of architecture is related to a process called architectural design, the articulation of spaces, forms, details and the construction of a building follow it. The content of two acts exhibit distinct characters; yet, rather than occurring as successive phases, designing and articulating designate an intellectual and practical relation. The essence of architectural practice, in a broad sense, resides in an intellectual effort depending on the intention of the architect. Behind the material reality of a built form, which is the concretized product of architectural practice, there is an intellectual effort: architectural design.

Architectural practice is initiated by designing, which exhibits an intellectual process. In her essay "Mimarklikta Felsefe Nerede Duruyor?" (Where does philosophy stand in architecture?), Ayşe Şentürer, architect, defines the design process as "an experiential, intellectual and critical decision process as a perceptual, conceptual, theoretical fact.",13

\footnotetext{
13 “... algısal, kavramsal, kuramsal, kurgusal, bir olgu olarak deneyimsel-düşünsel-eleştirel bir karar verme süreci..." Ayşe Şentürer, 2002, "Mimarlıkta Felsefe Nerede Duruyor?" in Mimarlık ve Felsefe (Architecture and Philosophy), Şentürer, A., Ural, Ş., A. Atasoy (eds.), İstanbul: Yapı Endüstri Merkezi Yayınları, p.134.(trans. by author). Şentürer presented this paper in the panel of "Architecture and Philosophy" hosted by ITU Faculty of Architecture in Taşkışla Campus, in 12-13 December 2002. The content of the panel, within the contribution of many philosophers and architects, was intended to question the relationship between architecture and philosophy. This relationship was discussed under some general topics such as "Architecture and Philosophy," Philosophy in Architecture/ Architecture in Philosophy," Discussions of "Architecture-Philosophy," and "Critical Views over the Architecture-Philosophy relationship." All discussions and papers presented in the panel are, then, gathered and published in a book, Architecture and Philosophy. In her paper "Where does philosophy stand in architecture?" which she presented in the panel discussions, Şentürer firstly focuses on the concepts of architecture and philosophy, and argues the way they are regarded as two relational disciplines; then she deals with critical interpretation of this realtion.
} 
As Şentürer points out, architectural design process embraces internally related mental phases, whose subject is the architect.

As an intellectual activity occurring in the architect's mind, the design process can be neither understood nor described explicitly. Since it is a subjective act, it is not possible to make a clear statement about this process. Hence, we cannot, in fact, expect an architect to make a clear statement about his/her architectural design processes. However, due to his intellectual contribution to architectural discourse, Steven Holl gives some clues about this subjective-intellectual-creative process of architectural design.

In this chapter the fundamental features of Holl's thinking of architecture will be examined by raising the following questions:

How does an architect start an architectural design? How does architectural design develops? What affects or guides this process? Such inquiries lead to examine a complex architectural structure. Architectural design embraces distinct acts that are internally combined within a process, which Holl relates with idea, concept, architectural thought, fusing of idea with phenomena, and a pre-theoretical ground, which will be examined further in the thesis. Behind examining his specific concepts, there is not any attempt to formulate Holl's architectural design. Instead, this examination aims at understanding the intellectual framework of his approach to architecture.

For Holl every design is a mysterious and unpredictable journey, which Alberto PérezGomez defines as a search for "the poetry of specifics." 14 In this search, aiming to capture the specific, the architect interprets limitless possibilities. Two main principles that underline Holl's design process can be denoted. Starting from "information and disorder, confusion of purpose, program ambiguity, infinity of materials and forms," every design becomes an experiment for Holl. ${ }^{15}$ There are no pre-determined premises

\footnotetext{
${ }^{14}$ Alberto Pérez-Gomez, 2003, "The Architecture of Steven Holl, In Search of a Poetry of Specifics" in El croquis (revised and extended edition, including issues 78, 93, 108), Mexico: Arquitectos Publishing, p. 547.

${ }^{15}$ Steven Holl, 1993, "Pre-theoretical Ground" in The Steven Holl Catalogue, Zurich: Artemis and Arcen Reve Centre d'Architecture, p.21.
} 
for the architect. On the other hand, his approach to architecture occurs within a phenomenological framework, which provides him a "pre-theoretical ground."

Holl interprets phenomenology as "a way of thinking for architecture." concern of phenomenology is the indeterminacy of perceptual experiences. Holl's emphasis on the experiential potential of architecture and the way lived experiences contribute to think on architecture becomes the ground on which phenomenology is related to architecture. As Pérez-Gomez mentions, "the possibility of an architecture that is capable of revealing the nature of experience... at the same time constituting its meanings through experience" establishes the phenomenological framework of Holl's architecture. $^{17}$

Steven Holl does not propose, indeed, any design method. On the contrary, he critically emphasizes that architectural design cannot be formulated or put into a methodological research. In this chapter of the thesis, rather than aiming to formulate or make a clear statement of Holl's design process, it is aimed to understand the process constituted on the basis of his particular concepts, while discussing, also, the philosophical depth of these concepts. This chapter incorporates the examination of the concepts that underlie Steven Holl's architecture, which are idea, concept, thought, and pre-theoretical ground.

\subsection{Idea}

From Greek philosophy to modern timesmany philosophers have elaborated on idea distinctly. Originating from the ancient Greek philosophy, idea, or eidos, has been linked to "vision" or "visual aspect." 18

\footnotetext{
${ }^{16}$ Steven Holl, October 2003, "Fikir ve Olgu, Steven Holl mimarlığının özeti” (Idea and Phenomena: The summary of Steven Holl's architecture) translated by Elif Kendir in XXI, vol.17, p.44.

${ }^{17}$ Op. cit. Pérez-Gomez, A., 2003, p. 546.

${ }^{18}$ The Encyclopedia of Philosophy, 1967, Paul Edwards (ed.), volume 3, New York: Colliar Macmillan Publishers, p.119.

Plato, (427-347 B.C.), based his philosophy on an unchanging, absolute entity, which he described through idea. For Plato, the sensory world we live consists merely of appearances of the absolute entity, while it is the ideas that exist; in other words, objects, he states, are merely the appearances of the ideas, Felsefe Sözlüğü (The Dictionary of Philosophy), 2002, Ahmet Cevizci (ed.), İstanbul: Paradigma Publishing, pp. 825-26. (trans. by author). In describing the Platonic 'idea' Cevizci emphasizes that sensory world of appearences become an imperfect copy of absolute ideas; On the other hand, Aristotle (384-322 B.C.),
} 
Maurice Merleau-Ponty's phenomenological philosophy depends on the concept of unity. He puts emphasis on the unity of human existence, which is made manifest as "the system of self-others-the world." ${ }^{, 19}$ While he rejects to detach soul or mind from body, he suggests that there exists "intercommunication" between distinct senses, wherein vision is an inherent dimension of tactile experiences, or vice versa. ${ }^{20}$ Within the framework of his overall approach, Merleau-Ponty discredits idea as an absolute, pre-constructed intellectual content that belongs to an isolated and inaccessible realm of ideas. His consideration of idea can better be comprehended in relation to the unity of existence that he puts emphasis on. For Merleau-Ponty what is visible and who sees, what is tangible and who touches are the parts of the same unity, which is existence. He describes the existence of the subject and the world on the basis of "flesh" that is "an element of Being." ${ }^{21}$ As it is the same body that sees, touches, smells, worries, or thinks, for the philosopher, bodily existence and its relation to the world become the fundamental means through which the realm of ideas can be comprehended.

For Merleau-Ponty idea is not "the contrary of the sensible," but rather "the lining and depth" of the sensible. ${ }^{22}$ Yet, idea is not perceptible or sensible, yet is conceivable and this conceivable intellectual content is internally linked to sensation, experience and perception, through which a material world is made manifest. The "primordial layer", which Merleau-Ponty describes as the realm of our experiences, is interpreted as the ground "ideas come into being." 23 Even though idea cannot be perceived or sensed, it is

Plato's student, critically emphasizes that Plato's theory of ideas as appearances of the transcendental universal truth fail to describe the physical existence of objects, Op. cit. Cevizci, A., p. 529; Having defined idea as "the content of sensation," and "the subjective and logical concepts of human reason," Descartes (1596-1650) believes that, what we experience is the eternally true idea, Ibid. p. 389; For Immanuel Kant (1724-1804) every possible experience involves "a priori principles," such as categories, in which "reason synthesizes the raw material of sensory experiences." Within the framework of his doctrine of categories, for Kant idea is "a compulsory, formal, organizer principle of reason, which cannot be objectively expressed," Ibid. p.528; For Hegel, (1770-1831), beneath the subjective existence of human reason resides the absolute human reason. ${ }^{18} \mathrm{He}$ describes this absoluteness "Spirit, Idea, Geist, Absolute, Absolute Reason," which "all objects of knowledge, of all universe" depend on, Ibid. p.477.

${ }^{19}$ Op. cit. Merleau-Ponty, M., 1962 (first published in 1945), p. 60.

${ }^{20}$ Ibid. p. 229.

${ }^{21}$ Maurice Merleau-Ponty, 1968, "The Intertwining- the Chiasm" in The Visible and the Invisible, Claude Lefort and Alphonso Lingis, translated by Hazel E. Barnes (eds.), USA: Northwestern University Press, p. 139.

${ }^{22}$ Ibid. p. 149.

${ }^{23}$ Op. cit. Merleau-Ponty, M., 1962 (first published in 1945), p. 219. 
the means through which sensibility is achieved. It is "the interior armature of which it [the visible] manifests. ${ }^{24}$ While visible is related to the experiences of the sensible world, the invisible designates the realm of ideas. The sensible world, thus, is the manifestation of the intellectual realm. As Merleau-Ponty states, "the experience of the visible world" is, indeed, "the exploration of an invisible." ${ }^{25}$ For him, conceivable ideas are also inseparable from phenomena. In considering idea as "a figurative meaning of vision", Merleau-Ponty puts forward an internal connection between idea and image. ${ }^{26}$ Idea manifests an indeterminate image that is the fundamental tool of thinking. “...it [idea] is the invisible of this world, that which inhabits this world, sustains it, and renders it visible. ${ }^{27}$ Consequently, Merleau-Ponty considers idea as the invisible force that generates the realm of phenomena; the means being by which phenomenal makes sense.

\subsubsection{Idea in Holl's Architectural Design}

Being subjective or the intimate content of the intellect, idea cannot be described or expressed explicitly. So, Holl does not elucidate what idea is; yet, he always tends to explain his understanding of architecture in his articles, where the development of his design process is mentioned. In this process, the way idea is formed and then generates architectural design lead to achieve inspiring suggestions for exploring an architect's approach to architecture.

Starting to design is the first, and perhaps the most severe, step of architectural practice. Holl, for whom design develops through an intuitive process, approaches to architectural design as an experimental process. First, he focuses on the idea of a project. For the architect, anything has the capacity to activate associations that will initiate the formation of an idea. Not only the physical world and the site serve as a field of research for the architect, but also he can be inspired by poetic, literary, mythical or spiritual themes. This intellectual concentration gradually leads to the formation of an idea. The idea is, indeed, a non-determinate image around which the architect elaborates his design.

\footnotetext{
${ }^{24}$ Op. cit. Merleau-Ponty, M. 1968, p. 149.

${ }^{25}$ Ibid.

${ }^{26}$ Ibid. p. 145.
} 
In Holl's architecture, it can be stated that phenomenal experiences continuously activate his architectural vision. As Merleau-Ponty proposes an internal connection between idea and the experience of phenomena, for Holl idea exhibits a relation with sensible, experiential and perceptible qualities. The "intertwining" of idea and phenomena, as Holl calls it, designates such a relation, through which the realm of ideas as the invisible is related with the realm of phenomena, which designate the visible. According to the architect, the invisible realm of ideas activates the phenomenal world to come into presence.

In his article entitled "Pre-theoretical Ground", Holl refers to Eastern Philosophy and concentrates on Japanese poetry. ${ }^{28} \mathrm{He}$ proposes a correspondence between Kajitsu, which is described as "poem's aspect and form," and architecture: " $\mathrm{Ka}$ is the beautiful surface of a poem," he states, "while jitsu, is the substantial core." ${ }^{29}$ Kajitsu designates totality through which the absence of a distinct attribute destroys the wholeness of a poem. The correspondence between kajitsu and architecture resides in the concept of unity that Holl presupposes for architecture. While architectural form can be interpreted as "the beautiful surface" of an architectural work, it is the idea that constitutes "the substantial core" of the architectural work. The articulation of a form presupposes an originating idea. This is the base through which architecture's power is made manifest. "It [architecture] can possess," states Holl, "both the core depth and the radiant surface by which to concretize the spirit." ${ }^{30}$

Steven Holl mentions:

"I would say that I am very interested in the philosophical nature of ideas as an origin, but I could not just stop there. My struggle is to try to find the phenomenal nature of the idea. I hope to connect the phenomenal properties with the conceptual strategy."31

${ }^{27}$ Ibid. p. 151.

${ }^{28}$ Op. cit. Holl, S., 1993, "Pre-theoretical ground," p. 23

${ }^{29}$ Ibid.

${ }^{30} \mathrm{Ibid}$.

${ }^{31}$ Op. cit. Holl, S., in Zaera Polo, A., 2003, pp. 21-22. 
Phenomenal qualities establish a field of research in Holl's architecture. The "phenomenal nature" of idea, as he mentions above, is related with an emphasis on the temporal relation between the subject and the world. Different from its metaphysical conceptions, idea, for Holl, is related with a distinct kind of reasoning whose foundation is the spatio-temporality of the subject.

"The idea is the force that drives the design," states Holl. ${ }^{32}$ As architectural practice is an intentional act, this intention is initiated within the formation of an idea. Idea presupposes an intellectual vision constituting the essence, or "substantial core," of architectural design, which Holl mentions as follows: "Focusing on ideas early in the design process sets the substantial core ahead to surface." ${ }^{33}$ Accordingly, the idea constitutes the base of architectural design leading to develop into an architectural work.

\section{2. "Pre-Theoretical Ground” of Architecture}

The examination of Holl's design process entails a focus on the "pre-theoretical ground" that he describes as the departure point of architectural design:

"In each project we begin with information and disorder, confusion of purpose, program ambiguity, infinity of materials and forms. All of these elements, like obfuscating smoke, swirl in a nervous atmosphere. Architecture is a result of acting on this indeterminacy."34

The pre-theoretical ground, which he explains through the words above, enables him to achieve a flexible architectural practice where he experiments with various concepts in each design. Focusing on program, site, culture, history, literary or mythical themes, the architect defines a pre-theoretical ground that provides him with achieving distinct starting points for each design. Nevertheless, the capacity of perceptual experiences to activate the intellect becomes the fundamental principle of the pre-theoretical ground, which Holl describes as follows:

\footnotetext{
${ }^{32}$ Steven Holl, (first published in 1996) 1998, Intertwining, New York: Princeton Architectural Press, p.15. ${ }^{33}$ Op. cit. Holl, S., 1993, "Pre-theoretical ground," p. 23.

${ }^{34}$ Ibid. p. 21.
} 
"Experience of phenomena -sensations in space and time as distinguished from the perception of objects- provides a "pre-theoretical" ground for architecture. Such perception is pre-logical i.e., it requires a suspension of a priori thought., ${ }^{, 35}$

For Holl, enabling an unmediated communication between the subject and the world, the realm of experiences signifies the possibility of an open-ended architectural field regardless of pre-determined limitations. Within this framework, phenomenology is primarily emphasized as a philosophy that generates the thinking of architecture and the articulation of architectural spaces, details and forms:

"Phenomenology as a way of thinking and seeing becomes an agent for architectural conception. While phenomenology restores us to the importance of lived experience in authentic philosophy, it relies on perception of pre-existing conditions. It has no way of forming a-priori beginnings. Making a non-empirical architecture requires a conception or a formative idea." 36

Holl argues that, the subject's lived experiences contribute the formation of his/her point of view, the phenomenological focus on the realm of experiences is essential in constituting the philosophical framework of the design process.

Having concerned with typological researches in architecture till the $80 \mathrm{~s}$, Holl focused on philosophy, which in turn constituted a turning point in his professional career. Under the light of his philosophical readings, he started to concentrate on phenomenology as an intellectual ground shaping his approach to architecture. In his article "Steven Holl: Proceedings of an elementary architecture" Frédéric Migayrou describes this transition in Holl's approach as "re-involving perception as a factor of direct organization of the architectonic field." 37

Steven Holl's phenomenological approach to architecture mainly depends on the phenomenology that Merleau-Ponty introduces with his philosophical arguments. In his book Phenomenology of Perception, Merleau-Ponty does not introduce, in fact, any

\footnotetext{
${ }^{35}$ Ibid. p. 23.

${ }^{36}$ Ibid. p. 21.

${ }^{37}$ Frédéric Migayrou, 1993, "Steven Holl: Proceedings of an elementary architecture” in The Steven Holl Catalogue, Zurich: Artemis and ArcenReve Centre d'Architecture, p.16.
} 
architectural theory. Rather, he examines the actual nature of human perception and behavior and concludes that perception is the foundation of all conscious action, constituting the basis of subject's "being-in-the-world."38 For him, due to the indeterminate nature of human existence, perception exhibits a mysterious, ambiguous, complex, and incomplete realm, which cannot be described by the determinate concepts.

Recognizing the experiential potential of architecture, Holl works with phenomenal qualities in designing and articulating spaces and forms. His emphasis on phenomenology of architecture helps to resist the loss of the experiential in the architectural realm. $\mathrm{He}$ promotes indeterminacy and experiments the unpredictable. However, this experimental approach should not be aligned with an empirical approach. That is to say, he does not achieve casual solutions, but rather searches for the particular. The pre-theoretical ground is this open-ended field of research through which particular ideas can be achieved.

\subsection{The Concept}

\subsubsection{The Formation of a Concept out of an Idea}

The examination of Holl's design process can be constituted through three major subjects, which are the idea as the intellectual base of the design, the formation of concept out of an idea and the elaboration of the architectural work, exhibiting, indeed, the successive phases of his architectural design. In his design process, he achieves particular concepts. The concepts are transformed into architectural spaces and forms. Before focusing on the significance of the concept in Holl's architecture, it will be appropriate to introduce the philosophical meaning of the word, which will help to clarify the architect's point of view.

A concept manifests "the mental design of an object in the mind." ${ }^{39}$ As the basic unit of thought, a concept is "the general design and the common properties of objects or events

\footnotetext{
${ }^{38}$ Op. cit. Merleau-Ponty, M., 1962 (first published in 1945), p. xi.

39، Bir şeyin, bir nesnenin zihindeki veya zihne ait tasarımı.” Felsefe Sözlüğ̈̈ (The Dictionary of Philosophy), Op. cit. Cevizci A. (ed.), 2002, p. 598.(trans. by author).
} 
expressed in a common noun. ${ }^{, 40}$ In his phenomenological philosophy Merleau-Ponty emphasizes, “...the sensation and images...never make their appearance anything other than within a horizon of meaning. ${ }^{, 41}$ Thus, the primacy of concept resides in its capacity to express the meaning of anything.

Merleau-Ponty focuses on a particular meaning that sensations and images are brought into existence. In other words, the way we conceive sensations and images reside in the meaning that they exhibit; otherwise, they do not make any sense. Due to this reasoning, concepts are interpreted as designating an image or sensation. ${ }^{42}$ They are the tools that generate human cognition.

The indeterminate idea in the intellect of the architect is transformed or designed into a concept, thus developing the design process further. The concept that Holl achieves sets the base for articulating space and form, with materials, details and light. Concept, as a tool for cognition, sets the essential "driving tool" of Holl's architectural design. ${ }^{43}$

\footnotetext{
40 " nesnelerin ya da olayların ortak özelliklerini kapsayan ve ortak bir ad altında toplayan genel tasavvur." Ibid. p. 599.(trans. by author).

${ }^{41}$ Op. cit. Merleau-Ponty, M. 1962 (first published in 1945), p. 15.

${ }^{42}$ Ibid.

${ }^{43}$ Op. cit. Holl, S., 2000, p. 346.
} 


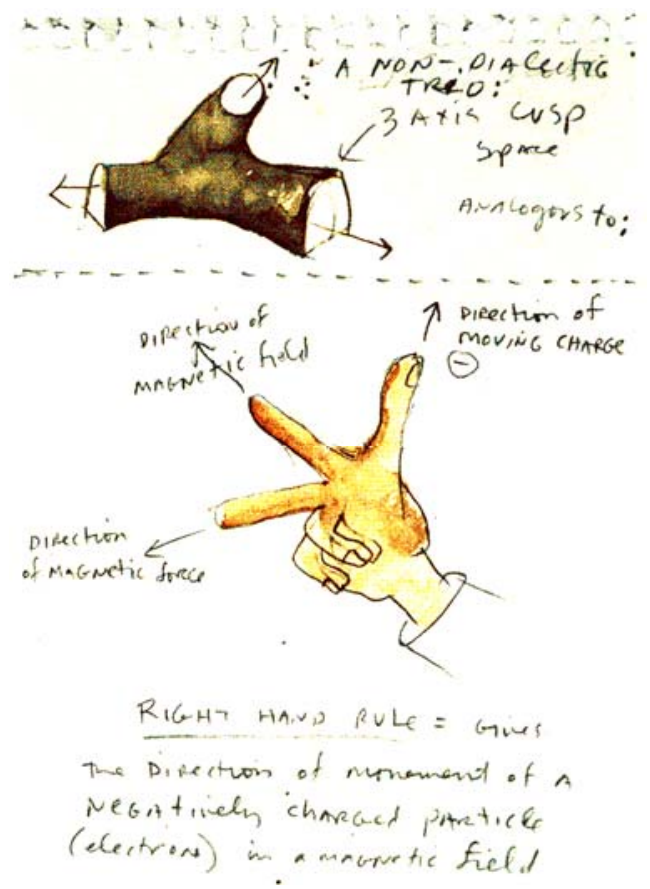

\section{Figure2.1. Initial sketch of the "Right Hand Rule" concept for Bellevue Art Museum, Washington, 1997.}

In the design of the Bellevue Art Museum, Holl starts with a concept of physics, the righthand rule. His experimentation of this concept is followed by achieveing the conceptual base of the architectural design.

He mentions:

"Forming a concept defines a field of inquiry -a territory of research for investigation that helps to form meaning. The idea is the force that drives the design. The field of inquiry sets the focus and the limit and, most importantly, the responsibility of work in rigor and depth." 44

When the architect achieves a concept, he is focused on a particular research area in the design process. "Abstract principles of architectural composition," he states, "take a subordinate position within the organizing idea," which exhibits a determinate concept. ${ }^{45}$

\footnotetext{
${ }^{44}$ Op. cit. Holl, S., 1998 (first published in 1996), p. 15.

${ }^{45}$ Op. cit. Holl, S., 1989, p. 12.
} 
The concept sets the network of relations, through which architectural form, details or material properties are developed.

The creative intellectual process of architectural design, for Holl, is an "abstract journey," wherein the architect aims at exploring new architectural horizons. In the "abstract journey," the formation of a concept out of an idea is established by "an interaction of the

mind and idea aimed at a process of crystallization." 46 The "crystallization," as he mentions, exhibits the formation of a concept out of an idea that leads to a progressive embodiment of the architectural design.

\subsection{2. "Limited Concept"}

The network of relations defined through the concept leads to set a focus, which Holl defines through "limited concept" as follows:

"Concepts, the tools one uses to drive the design, transcend ideological arguments. We work from a limited concept, unique for each site and circumstance. The limited concept gives us the freedom to work within the contingent and uncertain." ${ }^{, 47}$

Limited concept derives from the interpretation of the physical references of a site, history, culture, or program. Introducing a limited concept for each design, Holl develops an alternative position in architecture. As he states, a limited concept enables the architect to "illuminate the singularity of a specific situation"; while a defined territory is set forth, limited concept still enables him to deal with variations and diversity through which mystery is the departure point of the architect. ${ }^{48}$ In doing this, Holl avoids creating an architectural vocabulary or style, but rather searches for achieving particularity in each project.

\footnotetext{
${ }^{46}$ Op. cit. Holl, S., 2000, p. 346.

${ }^{47}$ Ibid.

${ }^{48}$ Op. cit. Holl, S., 1989, p. 12.
} 


\subsection{Architectural Thought}

Thought is defined as "the totality of processes, in which a conscious subject connects concepts in order to acquire knowledge." 49 Based on the philosophical definition of the term, thought manifests the ultimate product of a thinking process whose basic units are concepts.

Holl deals with architectural thought as a "structuring" thought, which he describes as follows:

"A structuring thought requires continuous adjustment in the design process to set manifold relations among parts within the larger whole. As dimensions of perception and experience unfold in the design process, constant adjustments aim at a balance of idea and phenomena."

For Holl the "structuring" function of thought in the design process derives from the intellectual power of combining or unifying the possibilities of various focus points into one whole. The formation of architectural thought is the phase of an intellectual process in which the architect makes determinate decisions about the overall configuration of the project. Thought is the combining motif of architectural design.

Merleau-Ponty dwells on the meaning and interaction area of thought, emphasizing that:

“...We are asking precisely what is that central vision that joins the scattered visions, that unique touch that governs the whole tactile life of my body as a unit, that I think that must be able to accompany all our experiences." ${ }^{, 1}$

In stating this, the philosopher attributes a central role to thinking within our intellectual and experiential life. At the core of our experiences and sensations, he says, lies thought, similar to the concept of "structuring thought" that Holl emphasizes on. For Steven Holl thought sets a connection between the sensible and the insensible, through which an interaction between mind and matter can be set forth.

\footnotetext{
49،bilinçli insan varlığının kavramları birbirine bağlamasını ve yeni bilgilere ulaşmasını mümkün kılan işlemler, süreçler bütünü.” Op. cit. Cevizci, A. (ed.), 2002, p. 329. (trans. bu author).

${ }^{50}$ Op. cit. Holl, S., 1993, "Pre-theoretical ground," p. 22.
} 
"Architectural thought," says Holl, "is the working through of phenomena initiated by idea." 52 As it is emphasized before, idea originates the act of designing wherein the intellectual realm constantly interacts with the realm of phenomena. Thus, thought is projected towards a phenomenal frame. As Merleau-Ponty states, "the infrastructure of vision" becomes the ground that thought emerges. ${ }^{53}$ With reference to Merleau-Ponty, Holl regards thinking and seeing as two interdependent acts, activating each other in the realm of architecture.

\subsubsection{Intuition, Truth, Culture and Architectural Thought}

Steven Holl states:

"Intertwining of the intellect and feeling is inherent in thought intuitively developed, thought that seeks clarity, rather than possesses truth, thought that searches and is open to the changing field of culture and nature that it expresses." 54

In Holl's words, three major themes come to the fore, which should not be disregarded in order to understand his thinking of architecture. Firstly, Holl proposes an intuitively developed thought. As the presupposed attribute of subjectivity, intuition contributes to the production of thought. Secondly, within the connection that he presupposes between thought and feelings there is a relative condition depending on its subjective presence. Thus, the subjective and relative attribute of thought leads to move away from completeness or determinacy of truth. Thirdly, as a subject belonging to a particular culture, the architect's way of thinking cannot be dissociated from cultural associations and culturally constructed meanings.

Intuition manifests an internal power that generates subjective acts. Beyond what has been taught or recommended, intuition is the reflection of intimacy. Holl suggests that architectural practice comprise, also, an intuitive act, by saying: "Intuition is our muse." 55

${ }^{51}$ Op. cit. Merleau-Ponty, M., 1968, p. 145.

${ }^{52}$ Op. cit. Holl, S., 1989, p. 11.

${ }_{54}^{53}$ Op. cit. Merleau-Ponty, M., 1968, p. 146.

${ }_{55}^{54}$ Op. cit. Holl, S., 1993, "Pre-theoretical ground," p. 23.

${ }^{55}$ Ibid. p. 21. 
The intuitively developed architectural practice exhibits, indeed, the subjective approach that the architect embarks upon. Holl brings forth an architectural approach that is generated by means of his internal dynamics. Within the framework of this intuitively developed architectural approach, thought is produced in the light of subjective attributes, past experiences and associations provoking the meaning that lived experiences are already charged with. That is to say, beyond yielding merely instinctive acts, in the realm of architecture, intuition is activated by cultural, historical natural or scientific inputs that contribute to the development of subjectivity.

In his article entitled "Teeter-Totter Principles" Holl uses a carpenter-architect analogy, which for him, can constitute a model for contemporary architectural practices. ${ }^{56} \mathrm{He}$ states that like a carpenter-architect, he develops a particular strategy in his practice. Not only his knowledge of traditional principles or techniques of carpentry, but also his intuitively developed way of making contributes to the formation of a subjective strategy of doing his job. Therefore, intuition and theoretical thinking, together, constitute the framework of carpenter-architect's practice. Due to this analogy, Holl aims to demonstrate that the architect makes a subjective contribution into the realm of architecture that cannot be predicted or pre-determined and this subjective contribution resides in intuition.
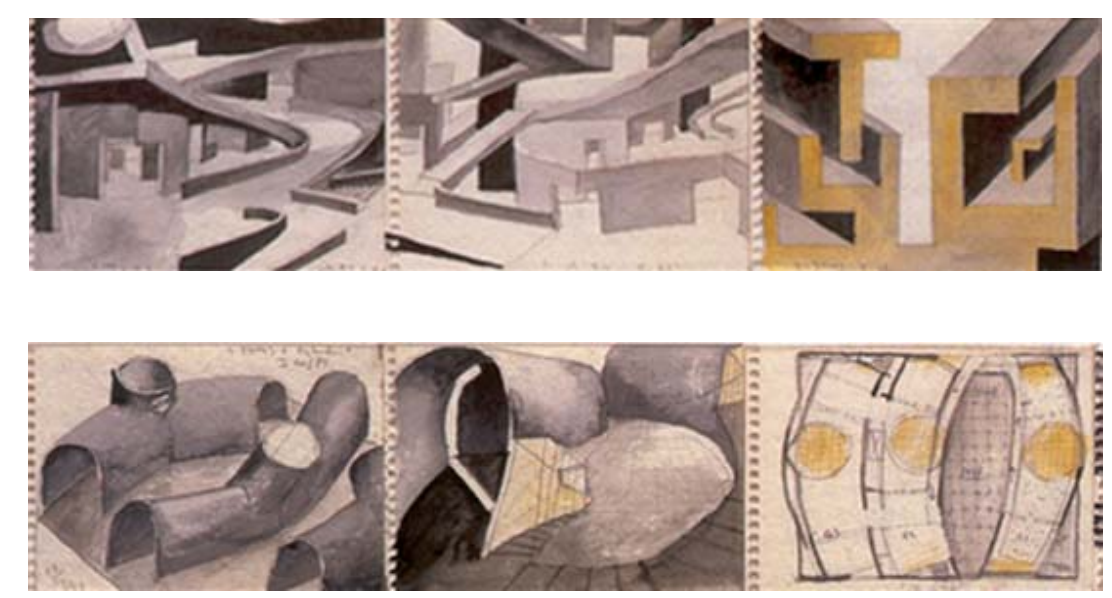

Figures 2.2. and 2.3. Search for the meaning intuitively developed in articulating spaces: Watercolor sketches of interior space for Bellevue Art Museum, Washington.

\footnotetext{
${ }^{56}$ Steven Holl, 1984, "Teeter-Totter Principles" in Perspecta, The Yale Architectural Journal no.21, Cambridge, Mass.: The MIT Press, p. 43.
} 
"Intuition led me to a hybrid mode between a conceptual framework and a phenomenological approach. I thought that light, texture, detail, and overlapping space constituted a 'meaning' that is silent and stronger than any textual manipulation." 57

As he states above, Holl's advance of intuition provides him an alternative intellectual process generated by the experiential realm. Intuition is related to unpredictable subjective experiences going beyond any stated concept. Exhibiting the inner faculty of the architect, intuition activates not only thinking, but also the act of building. Holl works on every design as an experiment through which he aims at exploring new ideas and then articulating them into spaces and forms.

However, as well as the contribution of intuition into the process, architectural practice involves economic or politic parameters that cannot be neglected within today's architectural practice. In her article "El Yordamıyla Mimarlık: Paralaks, bilinç, içgüdü ve Steven Holl" (Intuitive Architecture: Parallax, consciousness, intuition and Steven Holl) Ayşen Savaş, architect, critically argues, while intuition may yield an effective method for examining the physical environment, intuitively developed architecture could not avoid being a naïve approach. ${ }^{58}$

It is hard to argue the dominant role of financial and politic principles in today's building practices. However, when Holl's architecture is concerned, it can be stated that his intuitively developed approach leads to a particular practice that exhibits consistency. The consistency of his work depends on his phenomenological emphasis that the overall framework of his approach is informed. His intensive emphasis on the design of a detail or an urban design project develops within the framework of a phenomenological approach that brings forth a continuity and consistency in his practice.

Being intuitively activated and developed, Holl's approach to architecture brings forth an open-ended field of practice involving flexibility, yet specificity. He does not search for the ideal or universal. Thus, architectural thought does not exhibit a complete truth, but rather is relative and subjective. Architectural thought, for him, aims to reveal the "yet-

\footnotetext{
${ }^{57}$ Op. cit. Holl, S., in Zaera Polo, A., 2003, p. 15.

${ }^{58}$ Op. cit. Savaş, A., May 1995, p. 77.
} 
as-unknown," which is unpredictable. ${ }^{59}$ At this point, Holl approaches to the phenomenological conception of thought that Merleau-Ponty puts forward, emphasizing that:

“... my acquired thoughts are not a final gain, they continually draw their sustenance from my present thought, they offer me a meaning, but I give it back to them. Indeed, our available store expresses a forever afresh the energy of our present consciousness. Sometimes it weakens, as in moments of weariness, and then my 'world' of thought is impoverished and reduced to one or two obsessive ideas; sometimes, on the other hand, I am at the disposal of all my thoughts and every word spoken in front of me then stimulates questions and ideas, recasting and reorganizing the mental panorama, and presenting itself with a precise physiognomy. Thus what is acquired is truly acquired only if it is taken up again in a fresh momentum of thought..."60

Truth is related to a complete and stable condition expressing a common acceptance. However, Merleau-Ponty critically emphasizes that rather than expressing the truth, thought may diverge. Depending on the dynamism of existence, thought does not designate an unchangeable statement, but rather, it can be challenged due to the change of conditions. Thus, any lively event may yield or conduct the production of thought. The dynamic and varying field, through which a particular thought is produced, is the cultural and social environment that the subject lives in. Therefore, thought is related with a cultural or social framework, depending on the tradition of thinking that a distinct culture yields. The intellectual framework of a subject becomes meaningful through cultural associations.

Holl proposes a constant interaction between culture and the realm of architecture. While he defines architecture as "a cultural statement," his thinking of architecture becomes related to the cultural background of the architect. ${ }^{61}$

Merleau-Ponty argues that, while particular meanings are yielded within a culture, our lived experiences become charged with these meanings bringing forth an "outline" for present. ${ }^{62}$ This "outline" is related with our present perception and the way we think,

\footnotetext{
${ }^{59}$ Op. cit. Holl, S., 1989, p. 12.

${ }^{60}$ Op. cit. Merleau-Ponty, M., 1962 (first published in 1945), p. 130.

${ }^{61}$ Op. cit. Holl, S., 1984, p. 32.

${ }^{62}$ Op. cit. Merleau-Ponty, M., 1962 (first published in 1945), p. 13.
} 
which in turn penetrate the production of thought. With reference to Merleau-Ponty, cultural associations and culturally constructed meaning generates Holl's thinking of architecture. In his projects, he focuses on culturally constructed meanings, through which he achieves particular concepts. Thus, as he states, an architectural work becomes "a cultural statement."

\subsection{Architect as the Subject of the Architectural Design: The Subjectivity of Steven Holl}

Historical, geographical, cultural or social references may shape an architectural design, exhibiting the interdisciplinary dynamics in the field of architecture. Nevertheless, it should not be disregarded that also the subjectivity of the architect interacts with these parameters. As a subject, the architect should be distinguished as the basic presupposition of the architectural practice. Accordingly, an attempt to understand an architect's approach to architecture entails to unfold the subjectivity of that architect penetrating the former. In this part of the thesis it is aimed to examine Steven Holl as a subject: the architect.

The subjectivity of an architect can be investigated by raising the following questions:

Who is the architect? What does the architect do? What is the domain of activity for the architect? The architect is the subject of architectural practice involving thinking and making of architecture. In the distinct processes of architectural practices, the architect analyzes, observes, criticizes, interprets and produces. The architect has inter-subjective relations with things, others and the world; he/she is a part of a cultural group or society and has a particular past and identity.

As it is mentioned before, Holl departs from a "pre-theoretical ground" to reach to an idea and then transforms it into a concept, which in turn leads to an architectural thought. At this point, the way the subjectivity of the architect interplays within these processes gain an essential role in examining the architecture of Steven Holl. Not only consciousness, perceptual experiences, and cultural background, but also the subjectivity 
of the architect, his/her inter-subjective relationships with the world of phenomena can be denoted as the major qualities of the subjectivity of the architect.

\title{
2.5.1. Consciousness and Subjectivity
}

In his book Phenomenology of Perception, Merleau-Ponty states:

\begin{abstract}
"At the root of all our experiences, and all our reflections, we find a being which immediately recognizes itself, because it is its knowledge of both of itself and of all other things, and which knows its own existence, not by observation as a given fact, nor by inference from an idea of itself, but through direct contact with that existence. Selfconsciousness is the very being of mind in action." 63
\end{abstract}

As Merleau-Ponty mentions above, for a subject, to be self entails to be conscious. In other words, consciousness is the fundamental condition of subjectivity. Consciousness is awareness of things, others and the entire world. Consciousness, for Merleau-Ponty, enables the existence of "cognitive life, the life of desire or perceptual life" of the subject. ${ }^{64}$ Accordingly, any perceptual act of a subject presupposes the notion of selfconsciousness and to be conscious of his/her own existence, which in turn enables perceptual consciousness to operate.

In his essay entitled "Questions of Perception", Holl states, "An awareness of one's unique existence in space is essential in developing a consciousness of perception." ${ }^{65}$ In Holl's words it is possible to suggest that for him there exist a direct relation between perception and consciousness in the field of architecture. The architect is the conscious subject of architectural practice, through which he/she puts forward a particular purpose and labors at reaching it. Accordingly, the architect's self-consciousness is the fundamental prerequisite of architectural practice.

\footnotetext{
63 Ibid. p. 371.

${ }^{64}$ Ibid. p. 136.

${ }^{65}$ Steven Holl, 2003, "Questions of Perception" in El croquis (revised and extended edition), Mexico: Arquitectos Publishing, p.89.
} 
Architect is conscious of his physical environment that provokes him to think, design, and articulate. In his poetic writings Holl usually mentions the environmental experiences as exhilarating architectural thinking:

"The horizon is porous, percolating with our movement, under construction, or eroding in time. At night solids and voids reverse themselves in a spatiality of darkness. A kaleidoscope of color, a misty night in New York, is a marvelous liquid matter of green beyond yellow; reddish ridges undulating on a blue haze; orange blurs slowly, unfolding from shapeless marks to precise white glows. The spaces, buildings, window walls, signs, and colors intertwine. The glow of night's spatiality in the metropolis, a depth formed from shadows, colors and a light of sight, differs from the depth of daytime spatiality formed by the sun." $" 66$

The depiction of a New York night, above, reveals the poetic depth of his subjective experiences of the physical environment. Holl's consciousness of phenomena not only helps him to examine or unfold his environment, yet, and more essentially, guides architectural thinking and, then, the articulating of spaces and forms.

\subsubsection{Lived Experiences and Subjectivity}

According to Merleau-Ponty, lived experiences lead to set forth a particular framework through which our present perception and behaviors posses "a particular significance." 67 For him, depending on our experiences, meaning is yielded in the past and extends to the present. Present is already charged with meaning, while lived experiences form an essential part of subjectivity. The intimacy of experiences provides the subject to have a particular subjectivity that differs from others'. Being personal acts, experiences are related with subjective attributes, which Merleau-Ponty describes as follows:

"If it were possible to lay bare and unfold all the presuppositions in what I call my reason or my ideas at each moment, we should always find experiences which have been made explicit large-scale contributions from past and present." 68

The significance of lived experiences in Holl's subjectivity has a response in his architecture. Steven Holl, as an architect, interprets the physical environment as a

\footnotetext{
${ }^{66}$ Op. cit. Holl, S., 1998 (first published in 1996), pp. 12-13.

${ }^{67}$ Op. cit. Merleau-Ponty, M., 1962 (first published in 1945), p. 13.
} 
phenomenal field. In examining this field, he integrates the experiential realm to architecture, dealing with particular meanings conveyed through lived experiences. While lived experiences constitute the essential feature of subjectivity, the inherently conveyed meaning activates the imaginative creativity of the architect.

\subsubsection{Cultural Background of the Architect}

How subjectivity of the architect interplays within the design process is relational not only with his/her talent, consciousness, intentionality, and lived experiences, but also his/her cultural background, through which he/she develops a particular point of view. Culture is yielded within history, wherein particular meanings emerge. Culture enables us to grasp the meaning of our lives. Thus, culture becomes a fundamental feature of our subjective existence, as well.

It will not be irrelevant to look for the cultural clues within the practice of the architect. In his article "Edge of a City" Holl states, "An individual's cultural associations, recognition of materials and imagination of their properties, and the psychological effects of space and enclosure all present individual limitations." ${ }^{69}$ In stating this, the subject is interpreted as a perceiver; yet, it can be regarded that the perceiver, described here, can also be the architect as the continuous perceiver of the world surrounding him. It is this surrounding that bound him to a particular culture and this, in turn, contributes to the way he approaches to architecture. The meaning of our present experiences, for Holl, involves cultural and social impressions. While North Europeans know much about wood, for instance, stone is the primary scholarship of a Mediterranean worker. The geography, vernacular materials, and techniques exhibit a cultural specialization. Our perceptual experiences and the emotional effects of built environment on us, also, develop around cultural associations. Cultural associations of a subject are the way cultural meanings become activated within present thoughts. This interaction between the subject and cultural meanings occurs on the horizon of associations that contributes to the present.

\footnotetext{
${ }^{68}$ Ibid. p. 395.

${ }^{69}$ Steven Holl, 2003, "Edge of a City" in El croquis, revised and extended edition, Mexico: Arquitectos Publishing, p. 77.
} 
Holl points out to cultural associations that activate meanings in our present perceptions and cognition. Thus, a particular mode of qualification or control is signified. However, the architect points out that, associations may also lead to limitations, framing of subjective creativity.

Holl investigates cultural/local associations in architecture. He published various books exhibiting his considerable studies on building typologies; the series of Pamphleth Architecture (1977-1998), Foundations American House Types (1983), and Anatomy of a Skyscraper (1982) are within his publications. Searching for a synthesis in architecture as "a cultural statement" and architecture as "invention," Holl is striking for a balance in the field of architecture. ${ }^{70}$ His analysis and observation on building typologies provides him with developing a cultural knowledge of architecture.

\subsubsection{Intersubjectivity of the Architect}

In his book Phenomenology of Perception, Merleau-Ponty argues that experiences exhibit an intersubjective activity due to the potential one's experience is connected with another's. On the basis of perceptual experiences, he states, the subject has a lively communication with others and the entire world through which a system of "self-othersthings" is established. ${ }^{71}$ Merleau-Ponty points out to the co-existence of subjectivity and inter-subjectivity, which he describes as follows:

"The phenomenological world is not pure being, but the sense which is revealed where the paths of my various experiences intersect and engage each other like gears. It is thus inseparable of subjectivity and inter-subjectivity, which find their unity when I either take up my past experiences in those of the present, or other people's in my own."72

While experience is a personal act, it also leads to an intersubjective domain as "we experience a participation in the world."73 For Merleau-Ponty, on the horizon of the subject's inevitable relation with the world, an intersubjective realm is established.

\footnotetext{
${ }^{70}$ Op. cit. Holl, S., 1984, p. 32.

${ }^{71}$ Op. cit. Merleau-Ponty, M., 1962 (first published in 1945), p. 57.

${ }^{72}$ Ibid. p. Xx.

73 Ibid. p. 395.
} 
The subjective experiences of the architect lead to an architectural approach based on the horizons of experience. This approach is related to an inter-subjective domain: throughout the intellectual process of architectural design, the architect makes analysis, observations, and critiques on the physical environment he is located in. The architect, as "a subject being destined to the world," communicates with others by means of experiences. ${ }^{74}$ Holl's inter-subjective and experiential relations to the world contribute to his architectural design process. His awareness of the physical environment he is located in constitutes a field of research, which generates his creation of an architectural work.

\footnotetext{
${ }^{74}$ Ibid. p. xi.
} 


\section{CHAPTER 3}

\section{THE MAKING OF ARCHITECTURE: PHENOMENOLOGY OF THE CREATION AND EXPERIENCE OF ARCHITECTURAL WORK}

\subsection{The “Intertwining” of Idea and Phenomena through Architectural Practice}

The previous chapter of the thesis aimed to unfold the intellectual background of his architecture. In this chapter, it is focused on the way Holl makes architecture, which exhibits interdependence with the intellectual design process. It can be stated that a specific making of architecture follows the particular position he puts forward in his thinking of architecture.

Having defined idea as the "driving-force" of his architecture, Holl claims that it is through the experience of phenomena that the abstract, intangible level of architectural thinking is brought into a tangible level. Therefore, his articulation of spaces and forms occurs within the connection he proposes between idea and phenomena, intellect and feeling, concept and form.

With reference to Merleau-Ponty, Holl uses the term "intertwining" to describe the relation between idea and phenomena in the architectural realm. In his book The Visible and the Invisible, Merleau-Ponty points out the internal relation between the body and the world, wherein the two cannot be comprehended independently, but rather, presuppose each other. He describes the connection of body to the world as "the reciprocal insertion and intertwining of one in the other."75

Steven Holl metaphorically uses Merleau-Ponty's philosophical concept in order to define a particular condition in the realm of architecture. This condition designates the 
correlation of intellectual realm and the realm of experiences in every stage of architectural practice. As Merleau-Ponty defines the existence of body and the world with reference to the continuous interaction between them, Holl's architectural ideas are internally related with the realm of phenomena. Throughout his architectural practice, comprising thinking and making of architecture, a continuous interaction between architectural ideas and phenomenal world can be observed. The making of architecture cannot be constituted independently of an intellectual process; nevertheless, it is not merely the concretization of an idea. Rather, on the basis of "intertwining", the making of architecture, for Holl, includes both the formation of an idea and its translation into the realm of phenomenal experiences.

Holl's architectural practice occurs around the realization of such an intertwined relation. "The intertwining of idea and phenomena occurs," he states, "when a building is realized." ${ }^{, 76}$ Thus, the realization of an architectural work, for him, is the activity in which the "idea-force" of an architectural design is being concretized through the unity of idea and phenomena. Therefore, as Ole Bouman and Roemer van Toorn in their essay "On the Work of Steven Holl: Under, In, On and Over the Earth" mention, construction becomes the realization process or "architectural embodiment" of the unity of "intellect" and "experience."77

Through the realization of a building, as Holl calls it, the conceptual design becomes materialized by means of details, materials, light, color, and spaces. It is raised into a sensible state. While "an idea-force drives the design," states Holl, "structure, material, space, color, light, and shadow intertwine in the fabrication of architecture." ${ }^{78}$ The physical reality of a building offers phenomenal experiences, which enables a direct relation between building and perceivers. In the making of architecture, thus, the architectural idea is materialized into architectural forms and spaces.

\footnotetext{
${ }^{75}$ Op. cit. Merleau-Ponty, M. 1968, p. 138

${ }^{76}$ Op. cit. Holl, S., 1989, p. 10.

${ }^{77}$ Ole Bouman, and Roemer van Toorn, 1994, "On the Work of Steven Holl: Under, In, On and Over the Earth," in The Invisible in Architecture, London: Academy Editions, Berlin: Ernst\&Sohn, p. 92.
} 
Holl states:

"By making we realize idea is only a seed for extension in phenomena. Sensations of experience become a kind of reasoning distinct to the making of architecture." 79

The making of architecture is an activity that occurs through a specific intellectual frame, which indicates the subjective intellectual framework of the architect. Holl aims to fuse the realm of ideas with the realm of phenomena in order to create an architecture that is both intellectually and experientially intensive. The "extension" of idea into the realm of phenomena designates continuity; the physical reality of a building and the realm of experiences embodied in the built form constitute continuity between idea and phenomena, thought and feelings.

"Making architecture involves a thought that forms itself through the material in which it is made. The thinking-making couple of architecture occurs in silence. Afterward, these "thoughts" are communicated in the silence of phenomenal experiences. We hear the "music" of architecture as we move through spaces while arcs of sunlight beam white light and shadow."

As he mentions above, Holl puts emphasis on a particular architectural thought on which the constructing process of an architectural design depends. Architectural thought constitutes the specific frame of the act of building. There is a continuous interaction between the intellectual level of design process and the physical realization of architectural work. However, the "intertwined" relation he proposes does not indicate merely successive stages of a process, but rather comprises the interaction, or "insertion" of two processes which cannot be detached from overall architectural practice. The reason underlying Holl's use of the term "intertwining" depends on this kind of relation.

At the point ideas intertwine with phenomena in the architectural realm, the physicality of an architectural work and its relation to physical site are essential issues to be examined. The following section will examine the particular relation that Holl proposes between building, site and situation under the concept of anchoring.

\footnotetext{
${ }_{78}^{78}$ Op. cit. Holl, S., 1998 (first published in 1996), p. 11.

${ }^{79}$ Op. cit. Holl, S., 1989, p. 11.

${ }^{80}$ Op. cit. Holl, S., 1993, "Pre-theoretical ground," p. 21.
} 


\subsection{Anchoring}

In 1989, Holl published a manifesto called Anchoring as an architectural thesis whose departure point was "the particularity of situation." ${ }^{\prime 1}$ Holl states that, site and situation offer a particular field of research for each design, which provides him resisting not only homogenous building practices, but also the replication of context.

In using the term "anchoring", a particular relation between building and the site it is located in is made manifest. Not to speculate on his use of this particular term, it will be appropriate to introduce the dictionary meaning of the word:

"1. To place at anchor, to secure by an anchor.

2. To fix or fasten; to fix in a stable condition." $" 82$

While "anchor" is defined as the instrument that serves for the act of fixation, "anchoring" designates the act of fixation or the state of being fixed, which is often related with navigation. The anchoring of a ship means the way it is fixed to particular co-ordinates. Holl, on the other hand, uses the term as a metaphor indicating the fixation of a building onto a particular site. The physical relation between the site and the building is raised into a deeper and more intensive level. Rather than merely a physical settling down, anchoring designates a particular condition through which a building is rooted or connected into its site.

The term "anchoring" is used as a philosophical metaphor. As it is emphasized before, in proposing that idea intertwine with phenomena, Holl insists on a fusion between the intellectual level of idea with the experiential level of phenomena. Anchoring can be described, indeed, on the basis of this intertwined relation. While the abstract and non-

\footnotetext{
81 “... Fikirsel gelişmeme dair ikinci gösterge olarak 1989 yılında yazdığım Anchoring (Demir atma) başlıklı manifestodan söz edebilirim. Burada herhangi bir mimarlık yapıtı için, durum ve arazinin yalnızca o yapıta özel bir başlangıç noktası oluşturabileceği savını öne sürmüştüm... Başlangıç noktasını "durumun" özgünlüğünden almayan bir mimarlık yakalaşımı konusunda her zamankinden daha kuşkuluyum.” Op. cit. Holl, S. in Kendir, E. trans., pp. 44-46, (Trans. by author.)

82 "Anchoring" [Internet, WWW], ADRESS: http://dictionary.reference.com/search?q=anchor [Accessed: 15 April 2004].
} 
determinate nature of idea manifests a floating nature, anchoring becomes the fixation of the floating object, which is idea, into the realm of phenomena. In other words, idea anchors into phenomena.

The manifesto of "anchoring" designates a re-conceptualization of site in the realm of architecture. The way in which the relation of the building to the site is re-conceptualized in Steven Holl's architecture will be examined in the following section.

\subsubsection{Building, Site and Situation}

In his book Intertwining, Holl mentions three main "forces" of architecture, which he denotes as the "idea-force", "phenomenal properties" and "site-force". ${ }^{83}$ Among these three forces that generate his approach to architecture, the primacy of "site-force" can better be understood through the way architectural work anchors into the site and situation.

For Holl, architectural practice involves the responsibility of focusing on the site in architectural design. Thus, the site can be considered as offering a system of references that the architect re-interprets within the conception of architectural work. In his article "Modernizm'in Yerellikle Uzlaşma Araylşı. Holl” (Modernism's Search for Compromising with Locality: Holl.) Abdi Güzer, architect, points out how Holl integrates the site in his architectural conception and states that the site is the ground not only of building, but also of design concepts; in other words, for Holl site "is the ground on which both building and idea should be based on." ${ }^{\text {"4 }}$ Accordingly, the site is a fundamental reference generating Holl's architectural design. "We are always given a new site and situation," states Holl, "and we have to operate according to the conditions there." 85

\footnotetext{
${ }^{83}$ Op. cit. Holl, S., 1998 (first published in 1996), p. 16.

84 “....yer yalnızca yapının değil, tasarım düşüncesinin de temelini oluşturan, yapı gibi düşüncenin de üzerine kurulması gereken zemindir.” Abdi Güzer, May 1995 "Modernizm'in Yerellikle Uzlaşma Arayışı." Arredamento Dekorasyon vol.5 no.70, p. 73. (Trans. by author). Güzer teaches at the Middle East Technical University Department of Architecture as Assoc. Prof. Dr.

${ }^{85}$ Op. cit.Holl, S., in Zaera Polo, A., 2003, p. 15.
} 
The basic dimension of the relation between building and site is the inevitable physical connection between them. It is on the site that a building, as a physical reality, is constructed. Therefore, the building and the site are physically and functionally linked to each other since the building is permanently localized on the site. In his article "The Murmur of the Site" Rafael Moneo claims that the site is the "ground" in which a building is rooted; the site, he states, should be evaluated as the "basic material" of the building. ${ }^{86}$. For Moneo, it is on the basis of this physical link that architecture can be brought into being since "without the presence of the site, a singular and unique site, architecture cannot exist." $" 87$

Holl defines the uniqueness of each site for a building as presenting a specific situation. The dictionary definition of 'situation' exhibits the reason underlining Holl's use of the term in the realm of architecture. Situation is:

"1. Manner in which an object is placed; location, esp. as related to something else; position; locality site.

2. Position, as regards the conditions and circumstances of the case.

3. Relative position; circumstances; temporary state or relation at a moment of action, which excites interest.

4. Permanent position or employment; place; office. ${ }^{~} 88$

Situation is circumstantial or conditional. It comprises specific references and as a circumstantial case, situation is associated with current conditions making it particular.

For Steven Holl the site that a building is located in is unique. Every building has a particular site, which has intrinsic qualities, enabling to distinguish it from anywhere else. Situation designates the particularity of a site, which depends not only on its physical or topological qualities, but also the history of the site, the cultural references yielded by

\footnotetext{
86 “ Yer zemindir, bir yapının köklerinin daldırıldığı topraktır ve herhangi bir yapının kaçınılmaz ilk malzemesi olarak düşünülmelidir.” Rafael Moneo, May 1998, "The Murmur of the Site” (Yerin Fisıltısı) trans. by Dr. Emel Aközer, ANY Seçmeler, ed. Haluk Pamir, Ankara: The Association of Architects Publishing, p. 4, (trans. by author).

87 "Yer, mimarinin bir nesne olma özelliğinin güvencesi, özgül nesnelliğinin koruyucusudur. Yer olmaksızın, tekil ve benzersiz bir yer olmaksızın, mimari varolamaz." Rafael Moneo, May 1998, "The Murmur of the Site" (trans. by author). Ibid.

88 "Situation" [Internet, WWW], ADRESS: http://dictionary.reference.com/search?q=situation [Accessed: 15 April 2004].
} 
history, the meanings ascribed to the site and its memory. In other words, through situation a system of references for architecture is brought forth.

Holl relates architecture with situation, as expressed in the following words: "Architecture is bound to situation. Unlike music, painting, sculpture, film, and literature, a construction (non-mobile) is intertwined with the experience of a place. ${ }^{199}$ Through the relation he proposes between architecture and situation, the site of a building transcends being merely a physical ground, but rather the building becomes an inseparable part of a particular situation, which makes architectural work unique. Situation offers a relative and circumstantial locality that cannot be dissociated either from history, culture or from time and memory. Within this framework, the subjective perception of situation by the architect gains significance in Holl's approach to arcitecture.

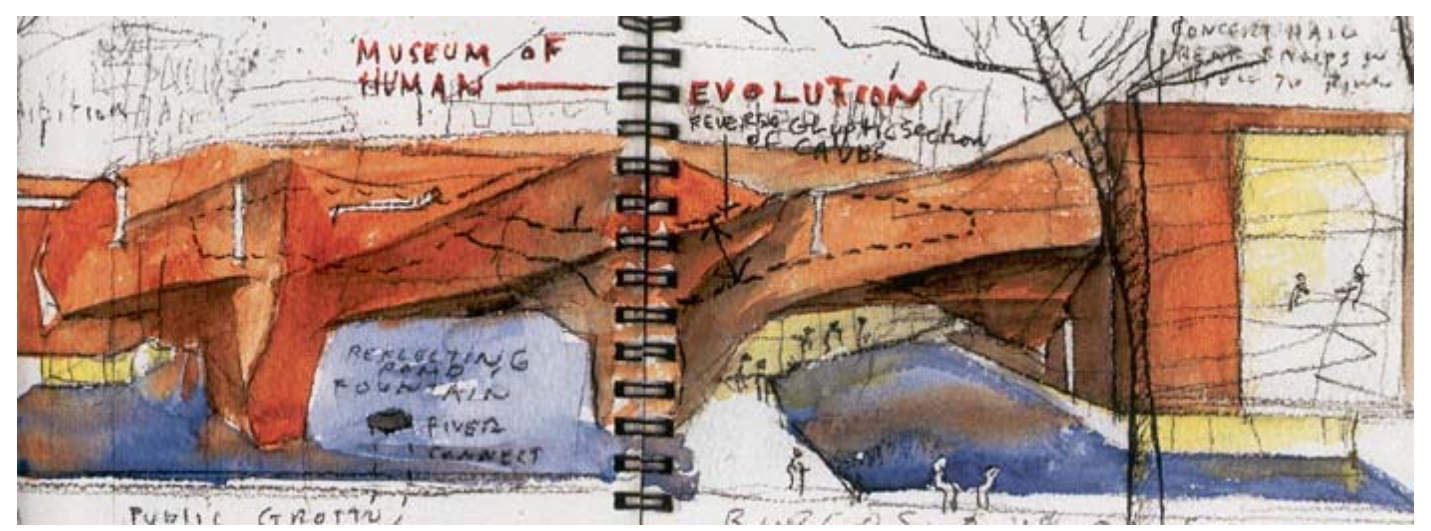

Figure 3.1. Watercolor sketch for Museum of Human Evolution, Burgos, Spain, 2000-

In the Museum of Human Evolution, the building is anchored into a situation generated through the history of the site, indicating a circumstantial locality which the uniqueness of the architectural work derives from.

By virtue of his emphasis on physical, historical, and cultural references of the site, it is possible to align Holl's work with contextualist approaches. However, the

${ }^{89}$ Op. cit. Holl, S., 1989, p. 9. 
phenomenological framework of his approach that underlines the particularity of his work should not be disregarded in understanding Steven Holl's architecture.

Based on the relation between the built form and the material environment it is located in, contextualism involves maintaining local continuity in architecture. Not only the environmental conditions such as topography, climate or light, but also, cultural references such as the tradition of construction technique, local identity, the use of local materials are the means a context is defined. In contextualism, a deterministic approach is put forward; the built form should exhibit visual, material and technical continuity with the physical environment it is located in.

For Steven Holl, on the other hand, the physical, historical or cultural references of a site, or even the memory of a site, present a particular situation. Every situation is unique and every situation establishes a specific context for architectural conception. However, this context does not offer a deterministic or objective condition. It is, rather, a subjective interpretation of culturally generated meanings or historical references, as well as the experiential physicality of the site. Holl brings forth an always-changing strategy that is based on a situation. The circumstantial qualities of a particular site present particular starting points for each design. For him, architecture takes references from situation. However, the situation does not designate a deterministic context. On the contrary, while it constitutes a system of references for the architect, he is able to reinterpret and reorganize the circumstantial qualities of a situation. Accordingly, architecture includes the power of creating its own situation, as well as taking references from the situation.

In his essay "The Work of Steven Holl: 1980-1996 A Retrospective Prospect," Frampton states that Holl's aim of integrating the building into the site designates a critical act wherein the architect has "the responsibility to challenge the site as to harmonize with it." "90 As Frampton points out, "anchoring" differs from an endeavor of retaining visual, material or technical continuity with the environment a building is located in. Within this

\footnotetext{
${ }^{90}$ Kenneth Frampton, 2003, "The Work of Steven Holl: 1980-1996 A Retrospective Prospect," in El croquis (revised and extended edition, including issues 78, 93, 108), Mexico: Arquitectos Publishing, p. 536.
} 
framework, Holl's architecture should be distinguished from contextualist approaches, since it introduces the possibility of developing flexible architectural strategies in which the architect rethinks and re-evaluates the circumstantial qualities of a situation depending on his/her experiences of it.

The anchoring of a building into its site, says Holl, can be established not only within a tangible level, but also, on a conceptual level that makes architectural work not familiar, but particular. In fact, it is hard to claim that Holl's buildings are harmonized with the environment they are located in. On the contrary, they are usually distinguished through their distinct and unfamiliar character. Hence, the way a building is "anchored" into its site, for Holl, depends on the architect's experience of it and it should challenge the existing situation, as well as respecting it.

Holl deals with site and situation through a phenomenological framework, emphasizing that:

\begin{abstract}
"One of the inspirations I drew from my early readings is phenomenology, particularly from Merleau-Ponty, was to grasp the profound uniqueness of each specific place, its light, its air, its smell, its ambient color, its history, or I should say, many histories. I realized that each site on earth was a different beginning point, experientially, historically, intellectually, capable of joining us together in new ways as our bodies move through it and as it, the place, moved through our bodies. This simple but deeply moving fact opened my mind to the possibility of a radical eruption in architecture, whose traditions and techniques I saw as more concerned with one or another mode of sameness, with typology for example, or historical contextuality." 91
\end{abstract}

Due to the flexible and open-ended nature of the connection that Holl proposes between "architecture, site, phenomena, idea, history," $" 92$ his architecture can be defined as a search for belonging to a specific situation. This attitude enables him to resist standardized, repetitive building practices. Anchoring is a strategy of individuality in which the individuality of situation is Holl's departure point for every project. The

\footnotetext{
${ }^{91}$ Steven Holl in Jeffrey Kipnis, 2003, "A Conversation with Steven Holl," in E lcroquis, revised and extended edition (first published in El croquis issue 93 November/December 1998), Mexico: Arquitectos Publishing, p. 42.

${ }_{92}$ Op. cit. Holl, S., in Zaera Polo, A., 2003, p. 15.
} 
architect does not search for the ideal. He aims to capture what is relative to situation, by stating: "An ideal exists in the specific, an absolute in the relative." 93

\subsubsection{The "Metaphysical Fusion" of the Building, Site and the Situation}

Steven Holl points out the metaphysical, experiential and poetic dimensions of anchoring, emphasizing:

"The site of a building is more than a mere ingredient in its conception. It is its physical and metaphysical foundation... Through a link, an extended motive, a building is more than something merely fashioned for the site... Architecture and site should have an experiential connection, a metaphysical link, a poetic link." 94

According to Holl, beyond the physical relation between the building and the site, they are also "metaphysically", "experientially" and "poetically" linked, which depends on the anchoring of an architectural work into its site and situation, indicating a deeper connection in the architectural field. It is this reasoning that Holl can be distinguished from other approaches concerning the building/site relation. As building anchors into a site, a particular condition emerges; a new situation is created. Not only the site offers a particular situation, but also anchoring presents a unique situation. This created situation, for Holl, is the base that the site and the building become "metaphysically" connected to each other.

In Helsinki Museum of Contemporary Art the metaphysical connection between the built forma and the site derives from the created situation; the fusion of the architectural work into the site.

\footnotetext{
${ }_{93}^{93}$ Op. cit. Holl, S., 1989, p. 9.

${ }^{94}$ Ibid.
} 

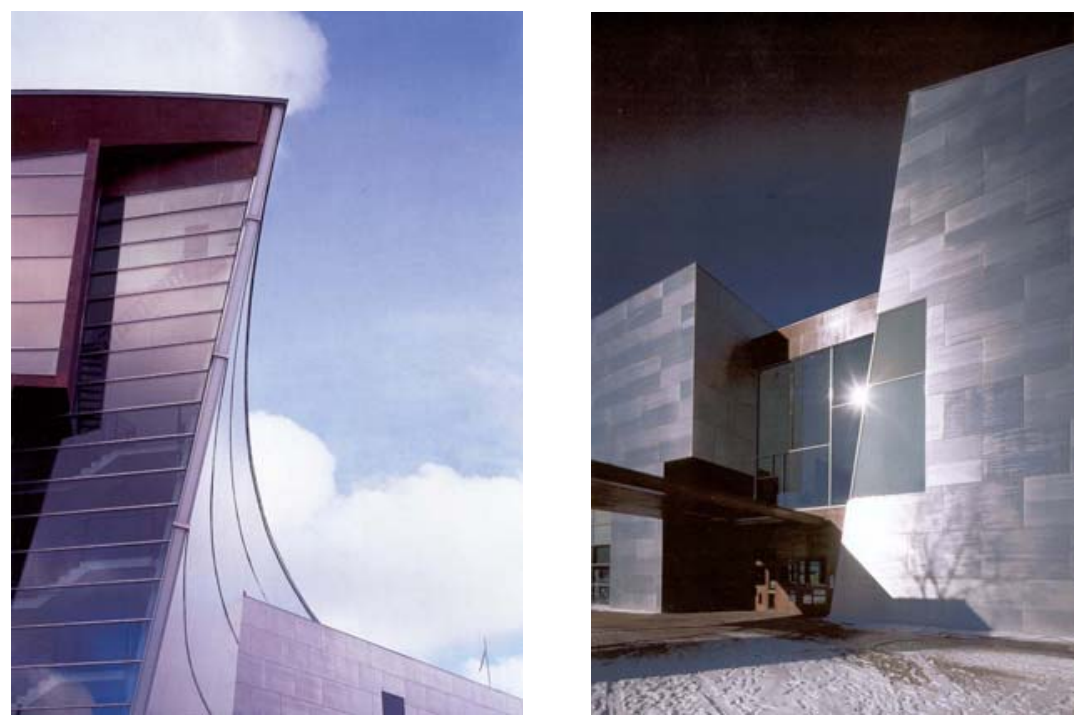

Figures 3.2. and 3.3. The metaphysics of place: Helsinki Museum of Contemporary Art, 1993-98.

The major challenge of anchoring resides in building's rootedness or being fixed into the situation. This approach reminds Heidegger's metaphor of "bridge" introduced in his philosophical arguments. Heidegger states that beyond its tectonic presence, the bridge defines a particular condition, which he describes as follows:

"The bridge swings over the stream 'with ease and power' It does not just connect banks that are already there. The banks emerge as banks only as the bridge crosses the stream. The bridge designedly causes them to lie across from each other. One side is set off against the other by the bridge. Nor do the banks stretch along the stream the one and the other expanse of the landscape lying behind them. It brings stream and bank and land into each other's neighborhood... The bridge gathers the earth as landscape around the stream... The bridge gathers to itself in its own way earth and sky, divinities, and mortals." 95

According to Heidegger, the bridge transcends its functional and physical reality, having a metaphysical meaning. For him the presence of the bridge depends on a divine reason. It is this reason that makes the presence of stream, banks, and landscape possible. The bridge includes their presence in its own being. A unity is made manifest through the

\footnotetext{
${ }^{95}$ Martin Heidegger, 1996 (first published in 1951), "Building, Dwelling and Thinking" in Rethinking Architecture: A Reader in Cultural Theory, Neil Leach (ed.), London: Routledge, p. 104.
} 
presence of the bridge. The "gathering" of the bridge, as Heidegger calls it, designates this act of unifying that not only enables, but also gives the meaning of their presence. The gathering of the bridge is the main reason it is a bridge.

"Building transcends physical and functional requirements," states Holl, "by fusing with a place, by gathering the meaning of situation." "96 Heidegger's emphasis on bridge's gathering of "earth and sky, divinities and mortals" can be related to the anchoring of a building into the site through "gathering the meaning of a situation."

Interpreting the relationship between building and site through a deeper connection, Holl claims that as the building fuses into its site, the meaning of situation becomes included within its presence. The scope of this inclusion is due to architecture's power of manifesting a particular meaning.

According to Heidegger, the bridge causes the banks to rest along the stream and brings the landscape next to the stream. In doing so, the bridge, says Heidegger, gathers the meaning of place. In Steven Holl's architecture, built form enables the meaning of a situation to come into presence through its own being, as the bridge does.

"When a work of architecture successfully fuses a building and situation, a third condition emerges," says Holl. ${ }^{97}$ Anchoring exhibits a particular condition where the building and the site are no more distinct entities. Rather, their fusion leads to the formation of a new, unified condition. This unified condition that is brought forth within gathering, metaphysically links architecture to the site. In other words, the metaphysical connection between building and its site is due to the way anchoring exhibits the gathering of a situation-dependent meaning into its presence as a built work.

With reference to Heidegger's metaphor of the bridge, the concept of anchoring designates a "third condition," as Holl calls it. Heidegger interprets the bridge's gathering

\footnotetext{
${ }^{96}$ Op. cit. Holl, S., 1989, p. 9.

${ }^{97}$ Ibid.
} 
of the fourfold of "earth and sky, divinities and mortals." ${ }^{.98}$ Being gathered exhibits a condition through which not the distinct presence of elements, as bank or as stream, but their unified presence is fundamental. Heidegger states that the bridge "allows a site for the fourfold. ${ }^{" 99}$ For him the bridge causes a site to receive its being. In other words, the presence of the bridge is regarded as the means a site is brought into being. In claiming this, the act of building is ascribed a purpose of defining spaces.

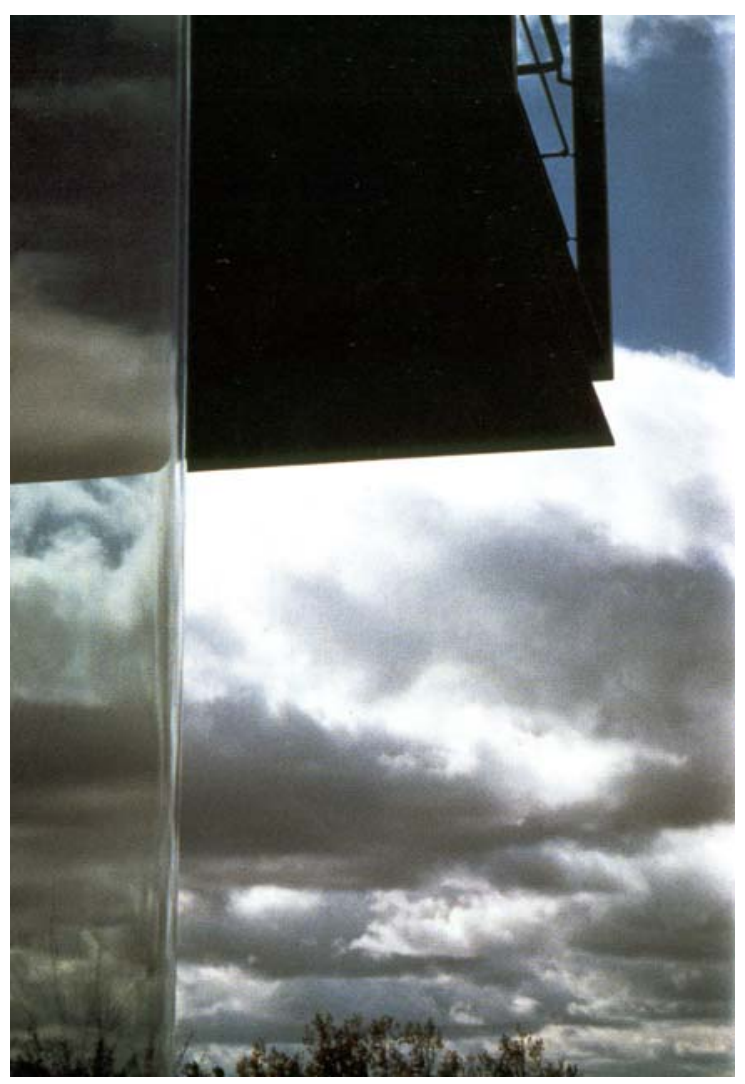

Figure 3.4. Building fuses through the situation: Y House, New York, 1997-99.

Holl, on the other hand, puts forward the concept of "illumination of a site," designating a condition related to anchoring. ${ }^{100} \mathrm{He}$ states: "Architecture does not so much intrude on a landscape, as it serves to explain it." ${ }^{\text {101 }}$ For Holl landscape can be explained by means of

\footnotetext{
${ }^{98}$ Op. cit. Heidegger, M., 1996 (first published in 1951), p. 104.

${ }^{99}$ Ibid. p. 105

${ }^{100}$ Op. cit. Holl, S., 1989, p. 9.

${ }^{101}$ Ibid.
} 
an architectural work. As the bridge enables the presence of a site by assigning "locations," 102 the anchoring of architecture into situation brings forth a particular condition through which the site becomes redefined. Architecture, for Holl, provides to define a site by "gathering the meaning of situation," within the physical presence of a built form. It is through the building's physical presence that a metaphysical connection between architecture and site is established.

\subsubsection{The Meaning in Situation}

As it is emphasized before, Holl introduces a situation-dependent architecture focusing on the intrinsic qualities of a site. The coming together of a site's intrinsic qualities brings forth a particular meaning that is unique to that particular site. Thus, the meaning that the architect concentrates on is situation-dependent.

Starting with the consideration that the site has Holl states, "...a presence and a meaning," Holl states that "you can choose to acknowledge it, or you can choose to ignore it." ${ }^{103} \mathrm{He}$ is among architects who put emphasis on the meaning in architecture. The historical and cultural references generate a particular meaning unique to a particular site and situation. At this point, it can be regarded that Holl approaches to MerleauPonty's emphasis on the cultural dimension of perception. For Merleau-Ponty, the bodysubject possesses a culturally constructed "world of thoughts" which conduct the way he/she experiences the world; the acquired thoughts of the subject, he states, offer a meaning, enabling him/her to be situated in the world. ${ }^{104}$ Merleau-Ponty's phenomenology depends on understanding body-subject as being in a particular situation where he/she is surrounded by a particular system of meanings.

As the body-subject is regarded to be in a particular situation, Holl relates architecture with situation. In doing this, the act of building is interpreted as an act through which meaning is gathered. However, this meaning is not a sacred meaning; the architect does

\footnotetext{
${ }^{102}$ Op. cit. Heidegger, M., 1996 (first published in 1951), p. 105.

${ }^{103}$ Op. cit. Holl, S., in Zaera Polo, A., 2003, p. 15.

${ }^{104}$ Op. cit. Merleau-Ponty, M., 1962 (first published in 1945), p. 130.
} 
not refer to an inherent meaning of a place. For him, meaning varies depending on the circumstantial qualities of a situation. The attitude of searching for the meaning of the site and situation in architecture makes Holl's approach relative and circumstantial. While the fusion of the building into its site leads to the emerging of a particular condition, "anchoring" becomes the state in which this meaning of the site is elucidated and re-evaluated by the architect.

Meaning has always been an essential theme in the realm of architecture. Christian Norberg-Schulz focuses on the concept of meaning within the framework of a phenomenological perspective depending on existential references.

In his book Genius Loci, Towards a Phenomenology of Architecture, Norberg-Schulz deals with the relation between building, place and the existential meaning, emphasizing:

"...building... gathers the properties of the place and bring them close to man. The basic act of architecture is therefore to understand the vocation of the place. In this way we protect the earth and become ourselves part of a comprehensive totality..."105

In Holl's architecture, there is a search for situation-dependent meaning where the building gathers this meaning through its physical and experiential presence. In NorbergSchulz's perspective as an architectural theorist, on the other hand, we come across another point of view to the issue of meaning in architecture. For Norberg-Schulz, the main reason underlining architectural presence is gathering the inherent existential meaning of the place. The "vocation" of a place, as Norberg-Schulz calls it, designates, indeed, a pre-constructed existential meaning. He introduces the term genius loci as manifesting the vocation of the place. Genius loci are defined as "the spirit" of a place that exhibits the given character of place, providing to define it. ${ }^{106}$ Referring to the ancient use of the term as a Roman concept, Norberg-Schulz states that, there exist spirits of places that "give life to people and places, accommodates them from birth to death,

\footnotetext{
${ }^{105}$ Christian Norberg-Schulz, 1979, Genius Loci, Towards a Phenomenology of Architecture, New York: Rizolli International Publications, p. 23.

${ }^{106}$ Ibid. p. 18 .
} 
and determines their character or essence." ${ }^{, 107}$ According to him, while genius loci cause the place to come into presence, architecture is responsible of gathering the spirit of place through its materiality.

Steven Holl's phenomenological approach differs from Norberg-Schulz's depending on the proposed existential roots of the place. The concept of anchoring Holl puts forward designates a distinct phenomenology whose base is not an inherent, pre-existing totality, but the particularity of situation that is relative and not given. The relation between a built form and its site does not depend on pre-conceived existential references, but rather an experiential one.

Holl claims that as building anchors into its site, it becomes charged with a meaning. The building includes the meaning offered by the situation, creating a particular experience of place. Anchoring causes a distinct experience to emerge that is unique to the created "third condition". ${ }^{108} \mathrm{He}$ concentrates on an experiential connection between building, situation and subject. This experiential condition is not given or pre-constructed, but rather depends on the subjective interpretation of the perceiver, independent of the place's "vocation" or "genius loci."

At this point it is essential to focus on what kind of phenomenology is suggested through anchoring. "Architecture and site," states Holl, "are phenomenologically linked."109 The phenomenological connection between building and site resides in the realm of experiences emerged through anchoring. This indicates a twofold condition; besides the physicality of the experience of place, architecture and site becomes metaphysically connected through which "the qualities of architecture is fused with the qualities and meaning of its situation." $" 110$

\footnotetext{
${ }^{107}$ Ibid.

${ }^{108}$ Op. cit. Holl, S., 1989, p.9.

${ }^{109}$ Ibid.

${ }^{110}$ Ibid. p. 10.
} 
Holl mentions his personal experience of Salk Institute as expressing the distinctness of experience of a place:

"At Louis Kahn's Salk Institute, there is a time day when the sun, reflecting on the ocean, merges with light reflecting on the rivulet of water in the trough bisecting the central court. Ocean and courtyard are fused by the phenomenon of sunlight reflecting on water. Architecture and nature are joined in a metaphysics of place."111

Through the unified experiential realm, which Holl explains above, the experience of the building and the site merge into a whole. In such a whole, the site presents not only a physical ground, but also a distinct experience of place, metaphysically connected to the building. Holl's concern for the phenomenology of place, involving both physical and metaphysical scopes, brings forth a re-thinking and re-interpreting of the relationship between building and site in architecture.

As Botond Bognar puts it, due to the changing cultural, environmental and natural conditions in today's world, the absolute and deterministic conception of genius loci should be reinterpreted in the virtue of "a more circumstantial approach."112 For Bognard rather than insisting on the pre-existence of genius loci, it can be "constituted and recreated by architectural interventions allowing room for unpredictable action and events." With the concept of "anchoring" he puts emphasis on, it can be stated that Holl offers such a flexible and circumstantial relation between architecture and situation.

\footnotetext{
${ }^{111}$ Ibid. pp. 9-10.

${ }^{112}$ Botond Bognar, November/December 1992, "Anywhere in Japan: An International Symposium on Space, Site, Place and Architecture," in Architectural Design vol. 62 no.11/12, pp. 70-72. In his article Bognar evaluates the arguments held in the Anywhere symposium. As one of the conferences organized by Any Corporation, "Anywhere" symposium was held in Japan between June $9^{\text {th }}$ to $11^{\text {th }}$, occurred with the participation of may architects, philosophers and artists, among whom are Jeffrey Kipnis, Arato Isozaki, Peter Eisenman, Tadao Ando, Rem Koolhas, Daniel Libeskind, Rafeal Moneo, French philosopher Jaques Derrida, Toyo Ito, Fredric Jameson, Paul Virilio, etc. The main subject of this symposium was to discuss the recent developments on information and communication technologies and how these developments led to enormous changes not only culture, natural and built environment, but also our understanding of them. The arguments aimed at rethinking the concepts of space, site, place and architecture on the basis of the unavoidable changes in the culture of millenium.

${ }^{113}$ Ibid. p. 72.
} 


\subsection{4. "Lived space" in the Anchoring of Architecture}

The relation Holl proposes between architecture, site and situation indicates, also, a phenomenological condition grounded on experiences, where the perceptual experiences of a subject make an architectural work is being lived. In Holl's architecture, the anchoring of a building to its site is interpreted as offering a phenomenal field wherein body, architecture, site and situation are in an experiential interaction. Therefore, the architect interprets architectural space as "lived space" within a phenomenological perspective.

In Makuhari Housing project, the architect concentrates on the architectural space as lived space activating the feelings of the inhabitants.

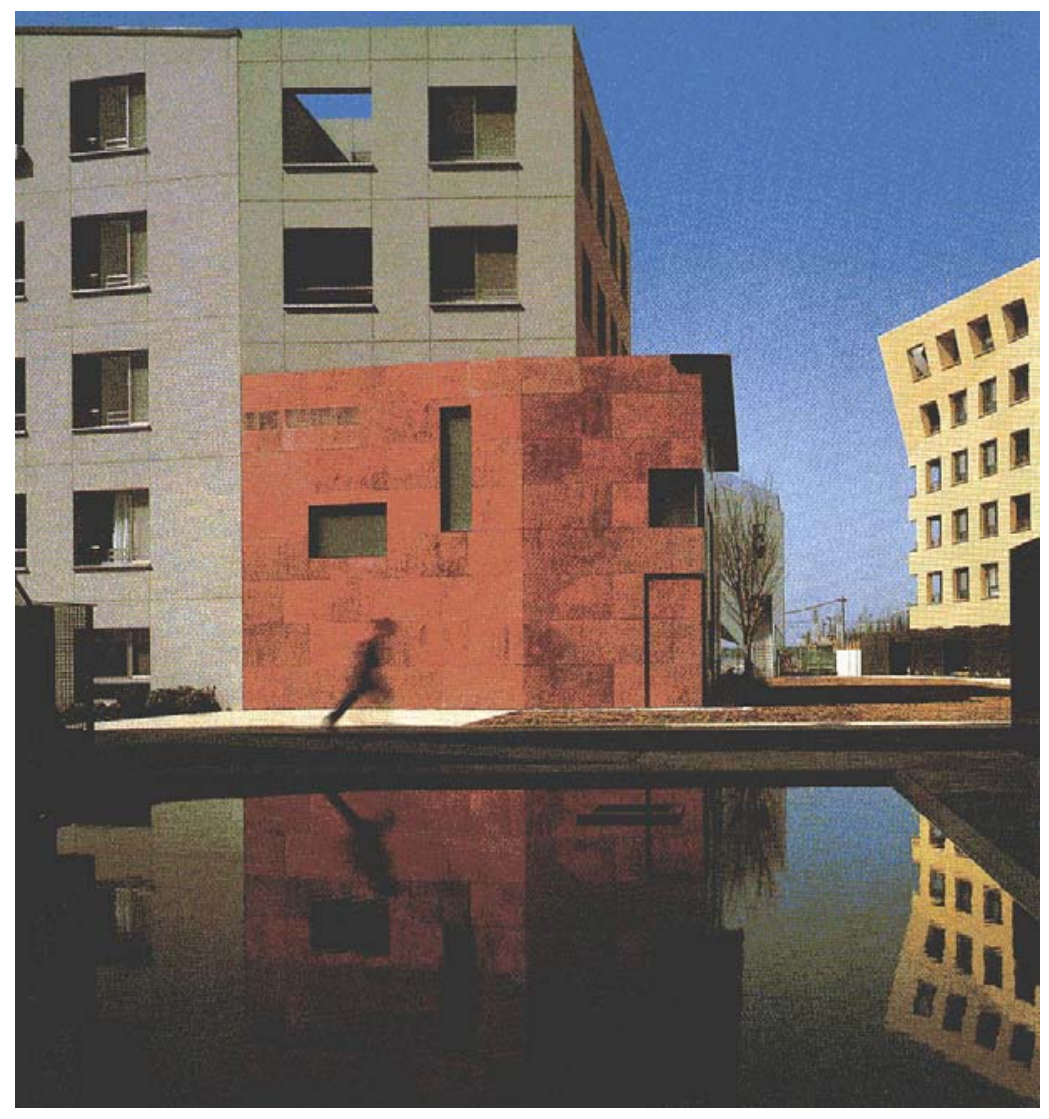

Figure 3. 5. Architectural space as lived space: Makuhari Housing, Japan, 1992-96. 
The concept of "lived-space" resides in Merleau-Ponty's phenomenological philosophy through which the relation between body-subject and the world is regarded as depending on lived experiences. ${ }^{114}$ In his book Phenomenology of Perception Merleau-Ponty brings forth the conception of "lived-through world," relying on body's lively connection to the world. ${ }^{115}$ Within the framework of the body's relation to the world, or rather to space, two important matters should not be disregarded. Firstly, Merleau-Ponty insists that the being lived of space resides in body's lived experiences and secondly, he puts forward the concept of "spatiality of situation" that human body inherently comes across. ${ }^{116}$

Merleau-Ponty interprets the body as a phenomenal and spatio-temporal being, which enables us to "anchor" to the world. ${ }^{117}$ Body is related to spatiality on the basis of being situated. For the philosopher, the spatiality of body cannot be defined by means of an abstract system of references, or coordinates. Since the body inhabits space and time, the spatiality of the body is a situation-dependent condition. While the situation-dependent spatiality of the body is circumstantial, and conditional, it is the body's spatial perception that makes the space being lived.

At this point, we come across a correspondence of Merleau-Ponty's philosophy in Steven Holl's architecture. The building's anchoring into its site approaches to the body's anchorage into the world depending on his/her spatial perception. As the body anchors into the world, for Holl the building anchors into a particular site and situation. While the anchorage of body into the world makes the space being lived, the anchoring of architectural work exhibits a phenomenological condition through which the perceiver is linked to the built work, site and situation on the basis of a lived-through relation.

To focus on a Heideggerian phenomenology and its reflection on Christian NorbergSchulz's architectural conceptions may help to better understand Holl's position in emphasizing the phenomenology of lived space.

\footnotetext{
${ }^{114}$ Op. cit. Merleau-Ponty, M., 1962 (first published in 1945), p. 286.

${ }^{115}$ Ibid. p. 60

${ }^{116}$ Ibid. p. 100.

${ }^{117}$ Ibid. p. 144.
} 
Martin Heidegger is an outstanding figure dealing with the relation between space, time and existence in philosophy. Heidegger's focus on phenomenology of space develops around the concept of dwelling. He emphasizes that dwelling is the fundamental ground of the relation between human beings, environment and existence.

In order to explain the concept of dwelling, he refers to the old German word bauen, by saying: "The way in which you are and I am, the manner in which we humans are on the earth as mortals, is Buan, dwelling." "118 According to Heidegger the phenomenology of space as lived space depends on human's dwelling; that is to say, beyond the intimacy of perception, sensation, or movement, to $d$ well occurs with reference to the inherent existential meaning of space. To dwell, then, is the means by which man is connected to space. "The relationship between man and space," he states, "is non other than dwelling." 119 Thus, man inhabits space and time, enabling to establish meaningful relations with his/her environment.

Heidegger focuses on architecture as a metaphor, through which he questions the relation of Being to the space. His philosophical arguments on space constitute an inspiring base for many architects among whom Christian Norberg-Schulz comes to the fore. NorbergSchulz questions the space of lived experiences within the framework of dwelling, in a Heideggerian sense. In his book Existence, Space and Architecture, Norberg-Schulz states that depending on "a need to grasp vital relations in his environment, to bring meaning and order into a world of events and actions," human being's relation with space have "existential roots." ${ }^{120}$ Man needs to bring the inherent existential meaning of space into presence, which is the basis of dwelling. As "the expression of human existence," space, states Norberg-Schulz, offers man the ground to live in. ${ }^{121}$

Consequently, in his phenomenological approach to space, which depends on the ontology of dwelling, Norberg-Schulz puts emphasis on the inherently existential

\footnotetext{
${ }_{118}^{11}$ Op. cit. Heidegger, M., 1996 (first published in 1951, p. 101.

${ }^{119}$ Ibid. p. 107.

${ }^{120}$ Christian Norberg-Schulz, 1971, Existence, Space and Architecture, New York: Praeger Publishers, p. 9.

${ }^{121}$ Ibid. p. 15.
} 
meaning of space that is manifested through built forms. For him, space is lived space as the ground man is able to dwell. The "lived" character of space is independent of its circumstantial qualities; but rather resides in the vital, meaningful and existential relation between man and his environment.

For Steven Holl, on the other hand, the phenomenology of lived space depends on the phenomenal experiences of the body that inhabits space and time. This reasoning constitutes the basis of his phenomenological position in the realm of architecture. As he points out, the phenomenal spatial experiences of the perceiver connect him/her to the architectural work. Thus, it is the experiential potential of architecture that makes it being lived, wherein architecture's power is made manifest.

\subsection{The "Intertwining" of the Body and the World}

In his phenomenological philosophy, Merleau-Ponty insists on the "incarnate subjectivity" 122 wherein our body is not only the means we exist in the world, but also "a natural self" that enables us to be individuals as subjects. ${ }^{123}$ Signifying the essential principle of his philosophy in which he is distinguished from idealist philosophical standpoints, Merleau-Ponty puts emphasis on the existential condition of "being-in-theworld." For him there exists a "lived-through" relation of the body to the world that "is not what I think, but what I live-through." 124

For the French philosopher, the body cannot be comprehended as a mere mechanical object; yet, it is not a constituting consciousness, either. However, the body is a self, which perceives and acts in the world, which is able to situate itself into the world through perceptual experience. The body and the world are not two independent or isolated entities. On the contrary, they presuppose each other, which Merleau-Ponty describes as follows:

\footnotetext{
${ }^{122}$ Monika M. Langer, 1989, Merleau-Ponty's Phenomenology of Perception, A Guide and Commentary, London: Macmillan Press, p. 53

${ }^{123}$ Op. cit. Merleau-Ponty, M. 1962 (first published in 1945), p. 206.

${ }^{124}$ Ibid. pp. xvi- xvii.
} 
"I understand the world because there are for me things near and far, foregrounds and horizons, and because in this way it forms a picture and acquires significance before me, and this finally is because I am situated in it and it understands me... If the subject is in a situation, even if he is more than a possibility of situations, this is because he forces his ipseity into reality only by actually being a body, and entering the world through the body. In so far as, when I reflect on the essence of subjectivity, I find it bound up with that of the body and that of the world, this is because my existence as subjectivity is merely one with my existence as a body and with the existence of the world, and because the subject that I am, when taken concretely, is inseparable from this body and this world." $" 25$

In Steven Holl's architecture we come across an awareness of body-subject's "livedthrough" relation to the world, in the sense Merleau-Ponty suggests. This lived-through relationship achieves an architectural response emphasizing the dependency of body and the space in architectural realm.

Holl explains this dependency through suggesting that there is an elemental relation between "Mind-Body-Environment" in which architecture can act as the fundamental discipline capable of "rebuilding" and "reconfiguring" this linkage. ${ }^{126}$ Holl's overall architectural approach is based on an attempt of linking the intellectual level of thought with phenomenal aspects. Motility is considered as being inseparable from bodily experiences in the "lived-through" relation between the body and the world. Within such a linkage, architecture becomes a fundamental medium connecting body to built form, both intellectually and experientially.

In denoting the three main generators in architecture as the "idea-force", "phenomenal properties" and "the site-force," Holl proposes that it is when these three "forces" merge into one that mind, body and environment become integrated. ${ }^{127}$ His emphasis on the notions of body, perception, movement, and experiences can better be understood within the framework of the elemental relation between "Mind-Body-Environment" he proposes. Merleau-Ponty's philosophy of the non-dialectic relation between the body and

\footnotetext{
125 Ibid. p. 408.

${ }^{126}$ Steven Holl, “Architecture=Integral Phenomena," [Internet, WWW], ADRESS: http://www.arch.columbia.edu/gsap/19006/ [Accessed: 19 December 2003].

${ }^{127}$ Op. cit. Holl, S., 1998 (first published in 1996), p. 16.
} 
the world allows us to understand not only the way Holl defines space with reference to body, but also, the relation he suggests between body, space, movement and time.

The "reciprocal insertion and intertwining"128 of body and the world, as Merleau-Ponty proposes, leads to an architectural response in Holl's work which he explains as follows:

\begin{abstract}
"In a three-dimensional triad, the reciprocal insertion of the body -oneself- in the interwoven landscapes of architecture yields identity and difference. This insertion of oneself is an intertwining of one in the other of architecture. Without purpose as an object, without recourse as a style, architecture depends on this reciprocal insertion of the other, oneself.", 129
\end{abstract}

While the architect focuses on the presence of a body in architectural design, the spatial perceptions of body are regarded as connecting the body to an architectural work. Through such an intertwined relation, building transcends being merely is an object, designating, rather, a living realm of experiences. Through our experiences of a built form, an "elemental connection" between architecture and the body becomes established. ${ }^{130}$ Since architecture has the potential to be experienced, the presence of body, which is the subject of perception, is an essential reference for the architect. Holl considers the body not a passive user, but rather as a perceiver who contributes the realm of architecture. Architecture's power depends on its capability to provide a communication between subject-body and the building.

\title{
3.3.1. A Philosophical Conception of Space:
}

\section{Merleau-Ponty and the Phenomenology of Space}

Merleau-Ponty defines space with reference to body, presupposing an intrinsic dependence between body-subject and space. In this part of the thesis, his phenomenological approach to space is examined in order to investigate the philosophical depth of space in Steven Holl's architecture.

\footnotetext{
${ }^{128}$ Op. cit. Merleau-Ponty, M. 1968, p. 138.

${ }^{129}$ Op. cit. Holl, S., 1998 (first published in 1996), p.16.

${ }^{130}$ Op. cit. Holl, S., 2000, p. 26.
} 
The philosopher brings forth the concept of "bodily space," through which the spatial character of human existence is signified. According to him, our bodily existence presupposes the notion of spatiality. Monika M. Langer defines Merleau-Ponty's conception on the spatiality of body as "the very way in which the body comes into being as a body." ${ }^{131}$ Merleau-Ponty insists on an inherent relation between bodily existence and space, wherein space is "already built into my bodily structure and is its inseparable correlative..."132 While the body is the means we are connected to the world, space is the ground this connection occurs. "... There would be no space at all for me," says MerleauPonty, "if I had no body." "133 Therefore, the presence of the body is interpreted as the primary condition that the presence of space is possible.

For Merleau-Ponty space cannot be comprehended in the absence of the subject since it is lived "only through the medium of subject who traces out and sustains it." "134 Accordingly, perception becomes an essential activity enabling us to the have access to the world; an essential characteristic of our bodily existence, which Merleau-Ponty describes as follows:

"The constitution of a spatial level is simply one means of constituting an integrated world: my body is geared onto the world when my perception presents me with a spectacle as varied and as clearly articulated as possible... This maximum sharpness of perception... points clearly to a perceptual ground, a basis of my life, a general setting in which my body co-exists with the world."135

Since the bodily existence of the subject presupposes spatiality, perceptual experiences provide an unmediated relation, enabling the body to be connected to and situated in the space. For Merleau-Ponty, both perception and spatiality are presupposed within the bodily existence of the subject, where "everything throws us back onto the organic relation between subject and space, to that gearing of the subject onto his world which is the origin of space."136

\footnotetext{
${ }^{131}$ Op. cit. Langer, M., 1989, p. 49.

${ }_{133}$ Op. cit. Merleau-Ponty, M., 1962 (first published in 1945), p. 142.

${ }^{133}$ Ibid. p. 102.

${ }^{134}$ Ibid. p. 244.

${ }^{135}$ Ibid. p. 250.

${ }^{136}$ Ibid. p. 251.
} 
The "gearing of the subject onto his world," as the philosopher puts it, achieves an architectural interpretation through Holl's emphasis on body's relation to architectural space, which is the main concern of following section.

\subsubsection{Body and Space in Steven Holl's Architecture}

Holl's denoting of the three main principles as the relation of body to space, the spatiality of perception and finally the notion of lived space, designates, indeed, his emphasis on the phenomenology of space he puts emphasis in architecture. Through his use of materials, color, light, and his focus on detail a phenomenological understanding of architecture and an awareness of its experiential potential is made manifest. He explains the importance of bodily presence that of experiences the architectural work, by saying: "The body is the very essence of our being and our spatial perceptions.",137

Holl considers the body as an essential feature of the architect's conception of space. Approaching, once again, to Merleau-Ponty's phenomenological philosophy, for the architect the body is not only the way we exist in the world, but also the subject of architectural perception. The body experiences the space. It is through the body that one is able to connect himself/herself to the space. As Holl mentions "...space is only perceived when a subject describes it."138 Presupposing the primacy of body in architectural conception, perception is interpreted as the means by which the space can be comprehended. As Holl mentions, "spatial definition is ordered by perception." 139 Within this framework, it can be stated that he brings forth a body-dependent approach to architectural space. Perception should not be disregarded in conceptualizing architectural space.

Holl's emphasis on body's spatial experiences can be related to the primacy of perception in providing the ground for body's "being-in-the-world." Perception enables the body to

\footnotetext{
${ }^{137}$ Op. cit. Holl, S., 2000, p. 13.

138 Ibid.

${ }^{139}$ Ibid. p. 26.
} 
acquire a lively communication with others, things and the entire world; being experientially connected to space, the subject perceives architectural space. Opposed to the homogeneous and abstract conception of geometric space, perceptual space is the lived space.

On the other hand, it is possible to mention different philosophical standpoints opposing to Merleau-Ponty's perception dependent phenomenology. Having defined the space as "an existential dimension" and "a relation between man and his environment," NorbergSchulz criticizes perceptual space in virtue of "existential space," wherein its inherent absolute existential meanings enable to achieve the stable and pre-structured character of space. $^{140}$

He states that throughout the body's instantaneous spatial perceptions, man is not able to establish the stable relation with existential space. ${ }^{141}$ While perception can only be a medium for acquiring "subjective architectural experiences", mentions Norberg-Schulz, neither the space can be formed on the basis of perception, nor architectural creation can be comprehended as a subject-centered act. ${ }^{142}$ In criticizing a subject-centered approach to space, Norberg-Schulz states:

"It is non-sense... to say that man is always at the center of architectural space, and that the directions of architectural space change with the movements of human body. Architectural space certainly exists independently of the casual perceiver, and has centers and directions of its own." ${ }^{143}$

For Norberg-Schulz architectural space can be defined as a fabricated or regulated form of existential space. However, this regulation of existential space into architectural space, for him, occurs independently of the body's perceptual experiences. On the contrary, the act of building aims at revealing the inherently existential meaning of space. Architectural work, he states, "embody existential meanings, making the world stand

\footnotetext{
${ }^{140}$ Op. cit. Norberg-Schulz, C., 1971, p. 14.

${ }^{141}$ Op. cit. Norberg-Schulz, C., 1979, p. 34.

142 Op. cit. Norberg-Schulz, C., 1971, p. 13.

143 Ibid.
} 
forth as it is." ${ }^{144}$ Accordingly, embodying the existential meanings is the fundamental characteristic of architectural space.

Norberg-Schulz's approach to architectural space independently of bodily presence and his/her spatial perception provides a different standpoint in distinguishing Holl's position. Holl's interpretation of phenomenology exhibits a particular poetic intensity, which reminds the phenomenological philosophy of Gaston Bachelard. In the following section, it is aimed to examine the poetic potential of architectural space in Holl's approach within a parallel reading of Bachelard's major work Poetics of Space.

\subsubsection{The Poetic Intensity in the "Lived Space"}

In Holl's architecture it is possible to observe a poetic intensity which can be related to the phenomenal qualities of his work. However, the architect works with the experiential potential of an architectural work; it is its capacity to activate feelings and sensations of the viewers in which a psychological dimension is signified.

In his article entitled "Edge of a City," Steven Holl put emphasis on the psychological dimension in defining architectural space. He states:

"Psychological space is at the core of spatial experience. It is intertwined with the subjective impression of actual spatial geometry and born in the imagination... It is in this mix, at its architectonic conception, that the spatial spirit of a work of architecture is determined...The psychic core of a room is like a rêverie. The room, an individual's place of periodic repose, either inspires or inhibits creative thought. Insight, fantasies, and imagination are fueled by the psychological space of the private interior."145

As he mentions above, Holl points out to the psychological condition involved in the spatial experiences of the subject. The psychology he deals with resides in the subjectivity of experiences. For him, it is not possible to dissociate spatial experiences either from the spatial effect offered by architectonic form, or from emotional and imaginative dynamics. Thus, a natural connection between the realm of experiences and

\footnotetext{
${ }^{144}$ Christian Norberg-Schulz, 1985, The Concept of Dwelling, New York: Rizolli, p. 19.

${ }^{145}$ Op. cit. Holl, S., 2003, "Edge of a City", p. 75.
} 
imagination is proposed. In doing this, Holl interprets the concept of "psychological space" as a definition of the space internally yielded by the subject. It designates the activation of thoughts, dreams, desires and imagination through which the subject redefines the space. Thus, psychological space manifests the subjective interpretation of the physical space that occurs in the context of the experiential realm. The psychological interpretation of space is related to the emotional condition of the subject. In other words, according to Steven Holl emotions condition and affect the way space is perceived. The emotional and imaginative dimensions of "psychological space" that the architect proposes, constitute the base on which he relates architecture to poetry. He concentrates on the emotional content of poetry as a metaphor manifesting the spiritual connection between subject and architecture that takes place in the context of experiential realm.

Holl mentions poetic spatiality. Through the emotional and imaginative potential of experiences, says the architect, architectural space exhibits poetic characteristics. Poetry, which involves both imaginative and existent aspects, becomes an effective medium for exhibiting emotional and experiential density in the architectural realm. The poetic intensity of the interior space can be stated as the characteristic quality in the Helsinki Museum of Contemporary Art. Holl works with architectural form, light and shadow effects in order to create a poetic spatiality in the museum building.
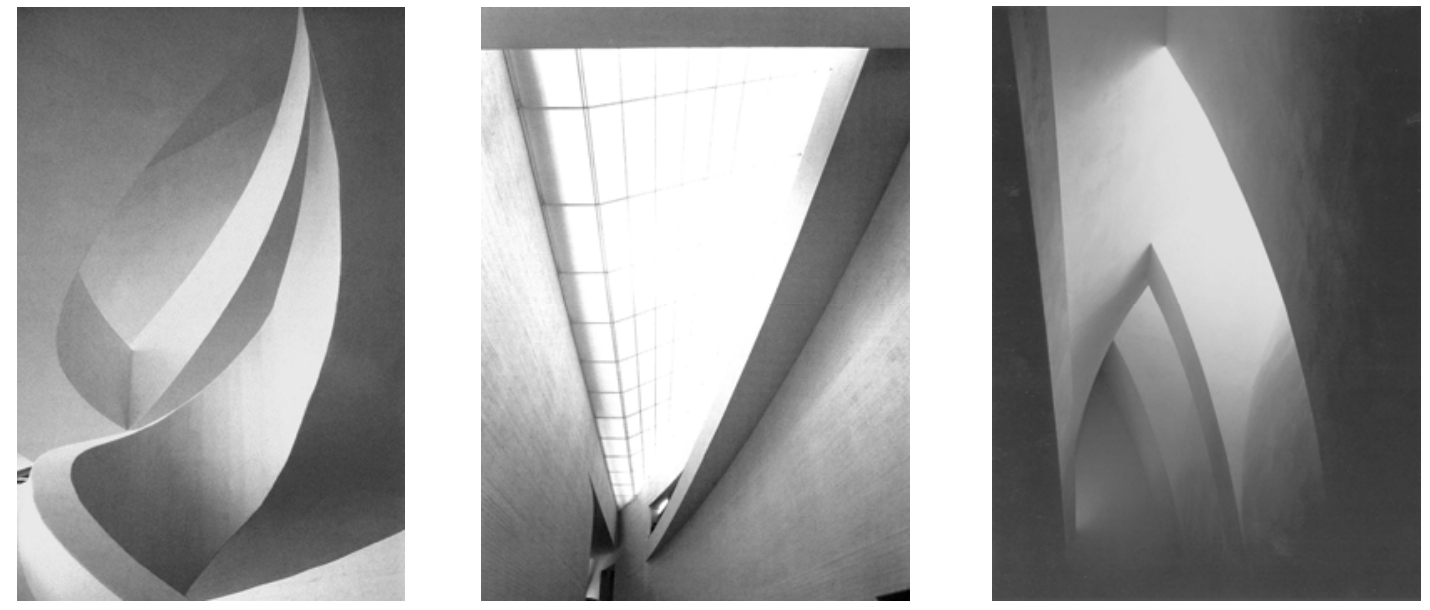

Figures 3.6., 3.7., and 3.8. Poetic spatiality: Helsinki Museum of Contemporary Art, 199398. 
"Experiencing the poetry of light and space is a confirmation of the exhilarating potential of architecture as a vessel for everyday life. From meditative space to inspiring details, architecture holds the potential to change the way we live."146

For Holl, the way human life is guided by architecture relies on experiences that are offered through a built work. The experiential qualities of a building present the inhabitant with emotional attributes.

The attitude of relating poetic sense of living to architecture originates Holl's emphasis on the concept of $d$ welling, which he focuses on as the ground that the poetic sense of life is made manifest. For Holl to dwell is not confined to the fulfillment of merely the physical requirements, but rather presupposes the spiritual and emotional contentment of human life. It is at this point that he attributes a conductive role to architecture as creating spaces for "sensory fulfillment". ${ }^{147}$ The architect focuses on the poetic sense of living that resides in the poetic dimension of dwelling in the context of the house. He states:

"The house is a home for the soul, the heart and the spirit. It is a container for the day's light, from the pale yellow of dawn to the deep blue of twilight. It is a box for the essential objects of life. It is a vessel for imagination, laughter, and emotion... and a silent space for the poetic sense of life."
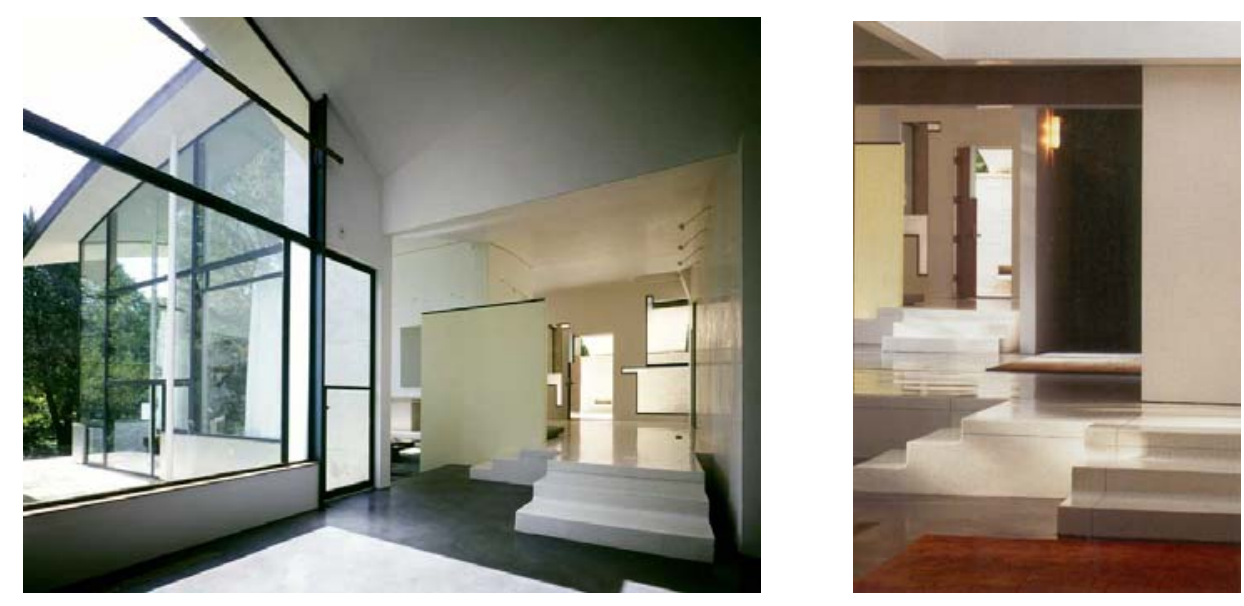

Figure 3.9. and 3.10. House as “a home for the soul”: Stretto House, Dallas, 1990-92.

\footnotetext{
${ }^{146}$ Steven Holl, 1993, "Dwellings," in The Steven Holl Catalogue, Zurich: Artemis and ArcenReve Centre d'Architecture, p.43.

${ }^{147}$ Steven Holl, "Phenomenology", [Internet, WWW], ADRESS:

http://www.arch.uiuc.edu/thesisstudio/tgs/history-3.htm, [Accessed: 30 June 2003].

${ }^{148}$ Op. cit. Holl, 1993, "Dwellings", p. 43.
} 
Thus, the house is considered as an essential architectural concept providing the subject to inhabit space and time. The house is interpreted as a private domain through which the subject faces his/her inner life; it is a place of interiority where imagination becomes activated. Due to this reasoning, the house offers "a home for the soul, the heart and the spirit," as Holl states above. Therefore, the act of living exhibits a poetic depth. The body-subject's inhabiting of space and time has a poetic nature, making space poetic. This poetic connection is an intrinsic characteristic of the act of inhabiting. Accordingly, a poetic link between architecture, space and life is proposed.

Holl's evaluation of the phenomenology of lived space approaches, at this point, to Gaston Bachelard's philosophy, the French philosopher (1884-1962), whose phenomenological arguments involve a focus on imagination and poetry.

In his major book Poetics of Space, Bachelard points out the symbolic meanings of space and subjectivity, which guide the way we perceive space. He claims that our perceptual experiences of physical environment involve an imaginative dimension, as well as being associated with reality, which he explains through "a phenomenology of imagination."149 Imagination is an inseparable part of perceptual experiences.

The privacy and subjectivity of perception constitutes the main framework of Bachelard's arguments. Perception is a subjective act; that is to say, we perceive the world according to ourselves, which is, in one sense, relative. For Bachelard, it is not possible to dissociate this subjective and private act from imagination. He states that spatial experiences embrace the experience of "reality and virtuality," which occurs through the intertwining of thoughts and dreams. ${ }^{150}$ The synthesis of "memory and imagination", says Bachelard, provides the ground for experiencing spaces in their reality and virtuality. ${ }^{151}$

In explaining the intertwined nature of spatial experiences, Bachelard puts forward the concept of "daydreaming," which for him is an inner act through which thoughts,

\footnotetext{
${ }^{149}$ Gaston Bachelard, 1969, Poetics of Space, Boston: Beacon Press, p. xix.

${ }^{150}$ Ibid. p. 5.

${ }^{151}$ Ibid.
} 
memories and dreams combine leading to a particular experience. ${ }^{152}$ Daydreaming start at the moment we move from physical experience towards an imaginary one wherein our memories, past, emotions and dreams intertwine with each other. This attitude of relating experiences to imaginative creativity is similar to the concept of "psychological space," in Steven Holl's architecture, where subject's fancied interpretation of space is emphasized. The architect interprets psychological space with reference to the subject's spatial experiences that depend on his/her emotions and dreams. Through the unmediated relation between spatial experiences and inner life, the subject redefines the physical space, attributing a psychological dimension to it.

In Bachelard's phenomenology, poetry is evaluated as an essential field of research where memories and thoughts intertwine with dreams and imagination. He focuses on spatial depictions in various poems, which for him "touch the ultimate poetic depth of the space." ${ }^{\prime 53}$ Bachelard puts emphasis on the images in poems; for him the poetic expression leads to the formation of image in the intellect of the reader. Thus, he points out that the spatial depictions of the poem generate the creation of a spatial image, which exhibits the creativity of imagination. Then, the reader finds himself/herself inside the space depicted in the poem, because the emotional and imaginary features of poetry, says Bachelard, give way for daydreaming. Therefore, the poetic depth of space depends upon nothing other than daydreaming. As poems include images, our spatial experiences involve particular images that yield symbolic suggestions. It is due to these suggestions that daydreaming occurs.

Bachelard focuses on the concept of $d$ welling wherein the house becomes his primary concern. The house, for him, is the primary medium of dwelling; it provides spaces for inhabiting, which he explains as follows:

"For our house is our corner of the world... it is our first universe, a real cosmos in every sense of the word. If we look at it intimately, the humblest dwelling has beauty."

${ }^{152}$ Ibid. p. 6.

${ }^{153}$ Ibid. 
Beyond its physical and functional qualities, the house, says Bachelard, offers spaces of inhabiting and constitutes a fundamental part of our lives. It exhibits the way we live. According to the philosopher, the house has poetic depth, depending on the poetic sense of dwelling. "...If I was asked to name the chief benefit of the house," he states, "I say: the house shelters daydreaming, the house protects the dreamer, the house allows one to dream in peace." 155

As the space of inhabiting, the house offers privacy and intimacy; it provides the most secure and protected ground for inhabiting. It is a place of our inner life, enabling us to daydream wherein the intertwining of thoughts, emotions and dreams take place. As Holl calls it, being "a vessel for imagination," the house provides "a silent space for poetic sense of life." ${ }^{\prime 156}$ Thus, it can be stated that in relating dwelling with the poetic sense of life, Steven Holl focuses on Gaston Bachelard's “phenomenology of poetic imagination," which he interprets as a philosophical metaphor in architecture.

\subsubsection{Motility of the Body in Space}

In his book Parallax, Holl puts forward a phenomenological understanding of space, which he mentions as follows:

"Motility and the body-subject are the instruments for measuring architectural space. Mundane phenomenological studies are as ineffectual as an overdose of wide-angle, distorted color photography. Only the criss-crossing of the body through space -like connecting electric currents- joins space, body, eye, and mind." 157

\footnotetext{
${ }^{154}$ Ibid. p. 4.

155 Ibid. p. 6.

${ }^{156}$ Op. cit. Holl, S., 1993, "Dwellings", p. 43.

${ }^{157}$ Op. cit. Holl, S., 2000, Parallax, p. 38.
} 

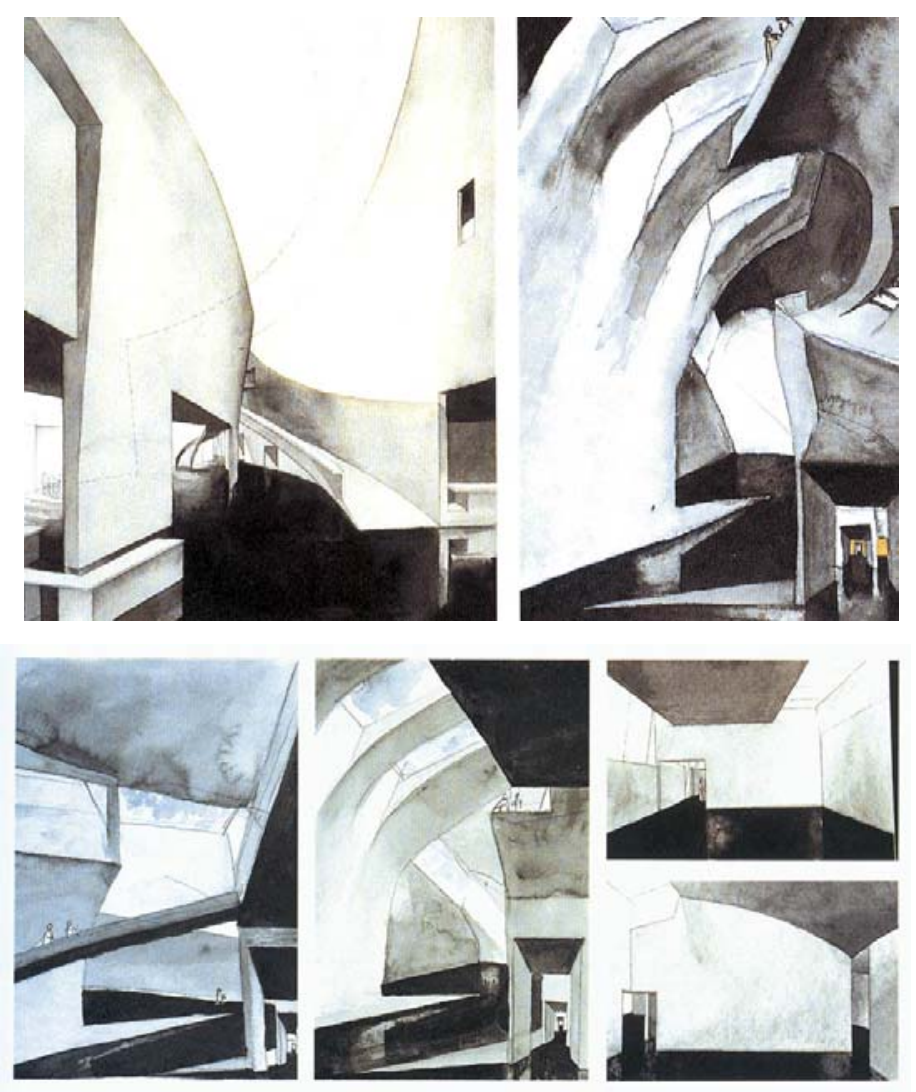

Figures 3.11. and 3.12. Looking for spatial perceptions of moving body: Helsinki Museum of Contemporary Art, 1993-98.

In his words it is noticeable that the spatial perception of the body constitutes an essential quality for Holl's articulation of architectural space. In articulating spaces, his departure point is the intertwined relation between the body and the world, which Merleau-Ponty describes as "the gearing of the subject onto his world." ${ }^{\text {158 }}$ For Holl, perception provides achieving this kind of a "gearing."

In the project of the Helsinki Museum of Contemporary Art the architect experiments varying spatial perceptions of moving body in the architectural space. His articulation of space develops around the experimentation of the feeling of space and the dynamism for the body in motion.

${ }^{158}$ Op. cit. Merleau-Ponty, M., 1962 (first published in 1945), p. 251. 
In the perceptual realm, movement is an essential quality enhancing the spatial perceptions of the body, apart from stable spatial perceptions. As a dynamic experience, movement occurs in space and time. Thus, movement renders the space a lived or perceptual space. Starting from the criss-crossing of the body through space and focusing on movement, Steven Holl proposes a new architectural strategy in which space is redefined, which will be clarified further in this section.

Merelau-Ponty regards movement as the bodily experience through which "the spatiality of body is brought into being." 159 At this point the notion of movement transcends merely changing of place or going from one point to another. Presupposed in spatio-temporal existence of the body, movement is an active experience. When movement is related to bodily existence, it becomes an inherent quality of perception that links the body to the world, in general, and to the space, in particular.

The philosopher considers motility and spatiality as two inter-related realms on the basis of bodily presence, by saying: "... there is no movement without a moving body." 160 This body is a perceiving subject who inhabits space and time. Thus, spatiality is presupposed in movement. Futhermore, motility is relational with the way space is perceived, since it offers dynamic spatial perceptions. "Indeed, it is not possible," says Merleau-Ponty, "to build motion out of static perceptions."

In Holl's work it is possible to observe that the body's spatial perceptions are worked with as the power of architecture can be transmitted. Holl points out the significance of movement as an essential consideration of spatial perceptions, which he mentions as follows:

"The movement of the body as it crosses through overlapping perspectives formed within spaces is the elemental connection between ourselves and architecture. The "apparent horizon" is a determining factor in the moving body's interpretation of space; yet the modern metropolis often lacks this horizon. Sequential experiences of space in parallax, with its luminous flux, can only be played out in personal perception. There is no more

\footnotetext{
159 Ibid. p. 102.

${ }^{160}$ Ibid. p. 268.

${ }^{161}$ Ibid. pp. 271-2.
} 
important measure of the force and potential of architecture. If we allow magazine photos or screen images to replace experience, our ability to perceive architecture will diminish so greatly that it will become impossible to comprehend it. Our faculty of judgment is incomplete without this experience of crossing through spaces. The turn and twist of body engaging a long and then a short perspective, an up-and-down movement, an openand-closed or dark-and-light rhythm of geometries- these are the core of the spatial score of architecture." 162

In Holl's words, a circumstantial condition is hidden where movement is interpreted as a physical act occurring in a particular space and time. He ascribes a spatio-temporal dimension for movement, which depends on bodily existence in a particular situation.

According to Merleau-Ponty every movement has a "background" which is not "a representation associated or linked externally with the movement itself, but is immanent in the movement inspiring and sustaining it at every moment."163 The "immanent" background of movement is, indeed, the world. When we return to Holl's approach, we find that he links movement to space. With reference to "apparent horizon," the body is able to perceive the space. "Apparent horizon" produces a subjective relation between the moving body and the space. It is this subjective relation that the body is related to architecture.
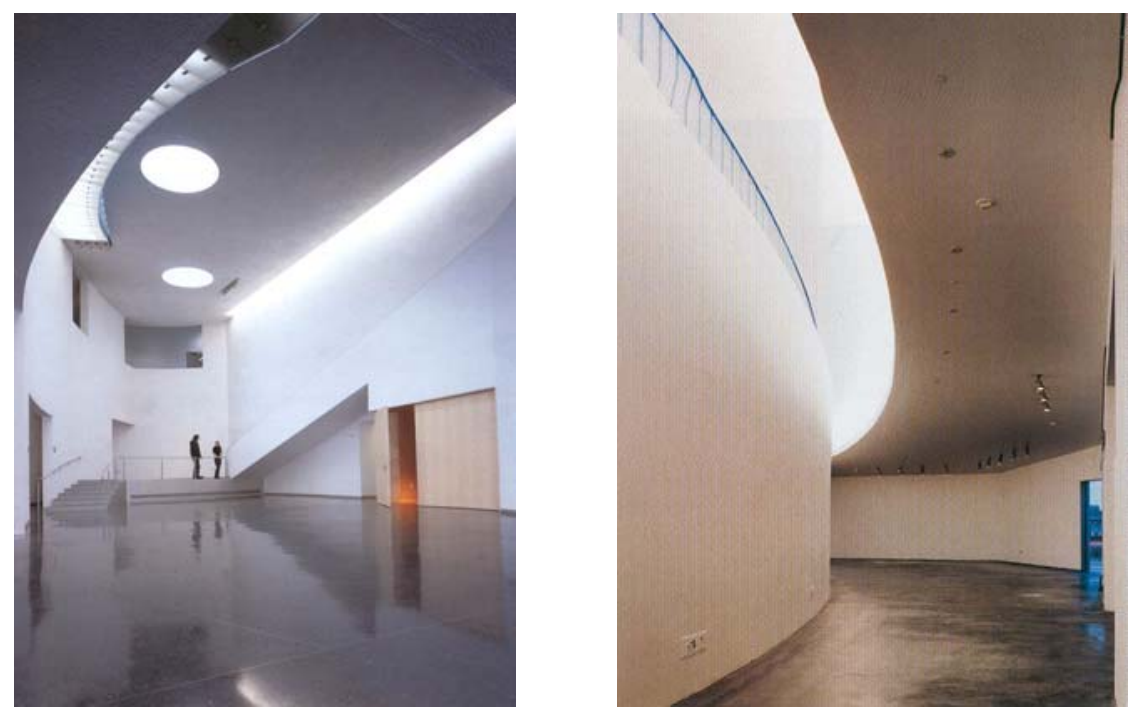

Figures 3.13. and 3.14. Overlapping perspectives of moving body in space: Bellevue Art Museum, Washington, 1997-2001.

${ }^{162}$ Op. cit. Holl, S., 2000, p. 26.

${ }^{163}$ Op. cit. Merleau-Ponty, M., 1962 (first published in 1945), p. 110. 


\subsubsection{3. "Parallax"}

Holl uses the concept of "parallax" as an architectural concept designating his emphasis on motility. He defines parallax as follows:

"Parallax -the change in the arrangement of surfaces that define space as a result of the change in the position of a viewer- is transformed when movement axes leave the horizontal dimension. Vertical or oblique movements through urban space multiply our experiences. Spatial definition is ordered by angles of perception. The historical idea of perspective as enclosed volumetric based on horizontal space gives way today to the vertical dimension. Architectural experience has been taken out of its historical closure. Vertical and oblique slippages are the key to new spatial perception. ${ }^{164}$

Parallax can be regarded as a new spatial definition that depends on body's movement in space. As the body moves in the space, his/her perceptual perspective changes leading to acquire successive, varying spatial perceptions. What Holl calls "parallax" is this fluid spatiality, through which the space is redefined. The space becomes redefined, on the basis of dynamic spatial perceptions of moving body. Holl describes parallax as "alwayschanging, visually tectonic landscape." ${ }^{\prime 165}$ While the varying nature of parallax is due to the body's motility, visuality of parallax is due to 'visual perception' of the body. Accordingly, through parallax dynamic appearances formed on the basis of body's perception and movement are offered.

Space, is in fact a stationary physical condition. Then, it is hard to suggest that space may have a fluid character. However, the fluid spatiality of parallax designates the varying perceptual experiences of moving body in space. The space is, still, stationary, yet spatial perceptions of the moving body are dynamic.

Holl interprets the concept of parallax as a tool in architectural design, claiming that it can be a medium of new spatial formations in architecture. Parallax can be regarded as a new representation of space the foundations of which are spatial perceptions occurring through motility. Parallax provides Holl with going beyond the two-dimensional

\footnotetext{
${ }^{164}$ Op. cit. Holl, S., 2000, p. 26.

${ }^{165}$ Op. cit. Holl, S., 1998 (first published in 1996), p. 12.
} 
representation of plan. For him, either the three-dimensional perspective is also inadequate for exhibiting the dynamic nature of space redefined through parallax. When the presence of body and the spatial perceptions of the moving body are taken into consideration, space achieves a forth dimension, which depends on the fluidity of spatial perceptions.

Holl mentions the "perspectival space" that is defined through parallax, which for him cannot be grasped within traditional architectural projections, but rather, entails a new medium:

"Overlapping perspectives, due to movement of the position of the body through space create multiple vanishing points, opening a condition of spatial parallax. Perspectival space considered through the parallax of spatial movement differs radically from the static perspectival point of Renaissance space and the rational positivist space of modern axonometric projection. A dynamic succession of perspectives generates the fluid space experienced from the point of view of a body moving along an axis of gliding change. This axis is not confined to the $\mathrm{x}-\mathrm{y}$ plane but includes the $\mathrm{x}-\mathrm{y}-\mathrm{z}$ dimensions manifesting themselves in the other dimensions, gravitational forces, electromagnetic fields, time, etc. Perspectives of phenomenal flux, overlapping perspective space is the "pure space" of experiential ground." 166
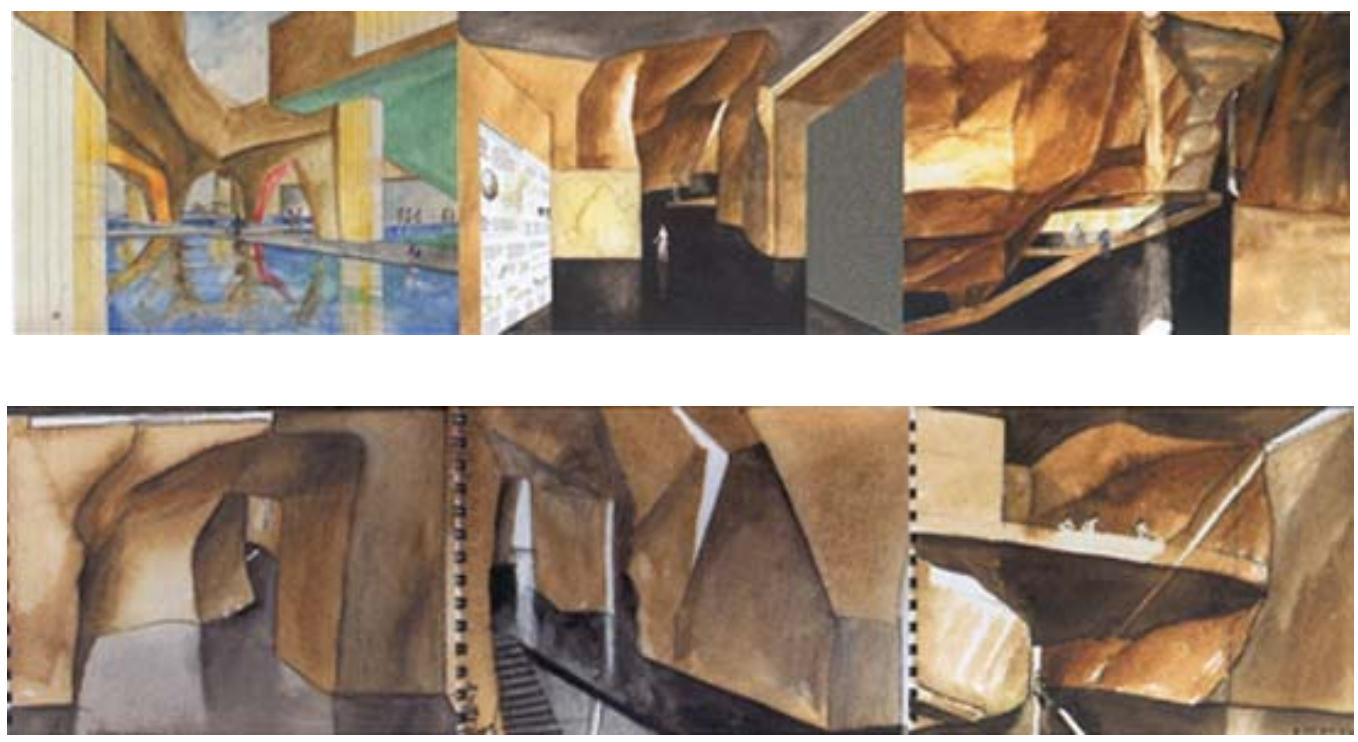

Figures 3.15 and 3.16. Spatial Parallax: Museum of Human Evolution, Burgos, Spain, 2000-

${ }^{166}$ Op. cit. Holl, S., 1993, "Pre-theoretical ground," p. 22. 
Holl's watercolor perspective drawings for the Museum of Human Evolution exhibit his focus on varying spatial experiences in architectural design. He puts forward a threedimensional design of architectural space, through which a moving body's active spatial perceptions generate spatial formation. In architectural design process, these perspective drawings precede the plan. Before he sets the plan, he draws a series of perspectives aiming to exhibit the varying spatial experiences of moving body in space. Having designed three-dimensional architectural space, the architect transforms it into the twodimensional plan. Hence, it can be regarded that he puts forward an inverse design strategy generated through parallax. In investigating various spatial perceptions, Holl aims at reaching the image formed in his intellect. Watercolor interior perspectives, the effects of light and shadow, the sense of depth, all exhibit an attempt to transform the insensible image into phenomenal aspects through spaces. In other words, he searches for reaching an architectural image through imagined perceptual experiences.

\subsubsection{Space-time Couple in Steven Holl's Architecture}

\subsubsection{The Spatiality of Time}

In his article entitled "Architecture in Space, Time" Jeremy Till argues that "... the reading of time through architecture is only possible spatially, and ... our experience of space is conditioned through time and memory." $" 167$ For him, architectural space cannot be comprehended independently of the notion of time, while time can be understood with reference to the physical environment.

Dwelled upon a phenomenological approach to architecture Steven Holl interprets space and time as two inseparable realms whose intertwining depends on the perceptual experiences of body-subject. The architect puts emphasis on the spatiality of time in which the presence of perceiving body is at the core of his consideration. This body is the phenomenal body inhabiting space and time. As Holl mentions, it is "the moving body through time."

\footnotetext{
${ }^{167}$ Jeremy Till, Nov./Dec. 1996, “Architecture in Space, Time” in Architectural Design vol. 66 no.11/12, p. 11.

${ }^{168}$ Op. cit. Holl, S., 2000, p. 184.
} 
For the architect, the space-time couple in architecture unfolds in the perception of time by the body-subject. Thus, we can mention the lived-time in architecture. The experiential relation of the body-subject to architectural space presents us with the notion of temporality in which lived time is also spatial. Holl states:

"As the subject occupies a particular time, space is thus linked to a perceived duration... Perception and cognition balance the volumetrics of architectural space with the understanding of time itself."

In his words, a focus on the experiential intensity and temporality of architecture is signified. The architect relates architecture to a situation in which the presence of body and the body's inhabiting of specific space and time gain importance. Holl points out the temporal experiences in the architectural field, depending on the temporality of the bodysubject and his/her perceptual experiences of the built form. Perception is a lived-through act inherently charged with the notion of time. Thus, spatial experiences of the bodysubject makes architectural space lived space that which unfolds in lived time.

Accordingly, Holl asserts that space cannot be comprehended by means of a merely abstract system of references. Rather, architectural space is full of phenomenal qualities in which material, detail and color and light merge with the notion of time. In using the term "perceived duration," the architect indicates a subjective interpretation of time by the body-subject in space. It can be stated that there exist two main principles behind his consideration of time: one is a temporal perspective dwelling upon the spatiality of time, and the other is related to the inner states of the body-subject in understanding the notion of time.

\subsubsection{The Subjective Interpretation of Time: "Duration"}

In his book Parallax Holl mentions:

"Time is only understood in relation to a process or a phenomenon. The duration of human beings alive in one time and place is a relational notion." 170

${ }^{169}$ Ibid. p. 13. 
For the architect, with reference to the Bergsonian duration every subject possesses a particular conception of time. Henri Bergson, the French philosopher (1859-1941), developed his philosophical arguments on the basis of "duration," which he considered as the fundamental content of time. According to Bergson, human beings posses "inner states" that can be described with reference to time, not space. ${ }^{171}$ Duration is "a measurable time" involving successive instants or states, presenting us with "inner duration." 172

Opening towards a Bergsonian perspective, Holl mentions duration of human being that is internal, subjective and relative. Duration in architecture manifests the subjective interpretation of time. "Time -as experienced duration- is," he states, "relative to an individual and to a space." ${ }^{173}$ As opposed to the definite conception of objective time in which "the series of possible relations in terms of before and after," is signified, duration dwells upon the subject's internal moments of time. ${ }^{174}$

The architect states:

"Is our sense of time specific to the collective culture into which we are born? Or does our inner life -when it is strongly felt- assert a transcendent pull on inner time redoubling in a healthy skepticism? Perhaps we each have our own psychic field of time to challenge the unconscious acceptance of a pre-described, commercially driven time."

As it is emphasized before, early in his carrier, Holl focused on cultural context and typology in architecture. Then, the scope of his study turned into a phenomenological perspective in which cultural and theoretical framework of his work merged with subjective insights and experiences. In other words, he acquired a phenomenological awareness in the realm of architecture. Within this framework, the influence of

\footnotetext{
${ }^{170}$ Ibid. p. 183.

${ }^{171}$ Jaques Chevalier, 1970 (first published in 1928), Henry Bergson, New York: Books for Libraries Press, p. 158.

172 "Henri Berg son's Time and Free Will: An Essay on the Immediate Data of Consciousness" included in p. 228, [Internet, WWW], ADRESS: http://spartan.ac.brocku.ca/ /ward/Bergson/berg02 toc.html

[Accessed: 24 April 2004].

${ }_{173}$ Op. cit. Holl, S., 2000, p. 188.

${ }^{174}$ Op. cit. Merleau-Ponty, M., 1962 (first published in 1945), p. 415.

${ }^{175}$ Op. cit. Holl, S., 1998 (first published in 1996), p.13.
} 
subjectivity in his architectural perception and cognition should not be disregarded. Dwelled upon a relational view of space-time couple in architecture, Holl points out the subjectivity of conceiving time; the conception of time is subjective incorporating the internal emotive and psychological motives of the body-subject.

"Time and perception in architecture," states Holl, "intertwine with light and space of architecture within a certain duration." ${ }^{\prime 176}$ The architect asserts that the phenomena of architecture reveal their significance through their potential to combine space, time and body-subject. Architecture comes into being when the realm of ideas "intertwines" with the realm of phenomena, presenting us with an intellectual and experiential depth in architecture:

"Architecture is a transforming link. An art of duration, crossing the abyss between ideas and orders of perception, between flow and place, it is a binding force. It bridges the yawning gap between the intellect and senses of sight, sound, and touch, between the highest aspirations of thought and body's visceral and emotional desires."177

\subsection{4. "Haptic” Sensibility in Steven Holl’s Architecture}

In a seminar held in Columbia University Department of Architecture, in 1992, Steven Holl made a speech entitled "Architecture = Integral Phenomena," where he described the fundamental purpose of architecture as follows:

"At the beginning of the $21^{\text {st }}$ century it appears clear that architecture can be the most effective instrument for reconstructing the relations of our species and the earth. There is no better tool than architecture to redesign the link between Mind-Body-Environment. In the field of vision where subjective aspects are magnified, the mind cannot be separated from its phenomenal senses via the body, which in turn should not be separated from the phenomenal aspects of architecture. The study of architecture is subjective, intuitive, psychological and scientific." 178

\footnotetext{
176 Ibid.

${ }^{177}$ Op. cit. Holl, S., 1993, Pre-theoretical ground," p. 28.

${ }^{178}$ Op. cit. Holl, S., "Architecture=Integral Phenomena," [Internet, WWW], ADRESS: http://www.arch.columbia.edu/gsap/19006/ [Accessed: 19 December 2003].
} 
For Holl, architecture's potential to connect mind with body and environment, depends on the realm of architectural experiences offered through the built form. Architecture is about a process through which what is designed in the intellect is, then, materialized. Intellectual design leads to a material product. As a material reality, built form is experiential. Therefore in the architectural realm, with phenomenal potential, the significance of bodily presence should not be disregarded.

At this point, the bodily experiences of human beings gain importance in Holl's architecture. For him the interaction between mind and body occurs with reference not to virtual, but the physical environment. Physical environment is not only the conceptual ground of Holl's architectural design, but also the material ground of the building. Consequently, the connection between "Mind-Body-Environment" resides in the experiential potential of the architectural work and the intimate contact the body establishes to it.

For the architect, a phenomenal field is presented through the physicality of the built form. In this phenomenal field there exist visual, tactile, aural qualities, even sense of odor. The use of material, the design of details, color, light and shadow effects establish a phenomenal realm, which is distinctive to architecture. Steven Holl uses the term "haptic realm," which for him best manifests the multi-sensory phenomenological qualities of architecture: "The smell of rain-wet dirt, the texture merged with the color and the fragrance of orange rids, and the steel-iced fusion of cold and hard: these shape the haptic realm." $" 179$

\footnotetext{
${ }^{179}$ Op. cit. Holl, S., 2000, p. 68.
} 


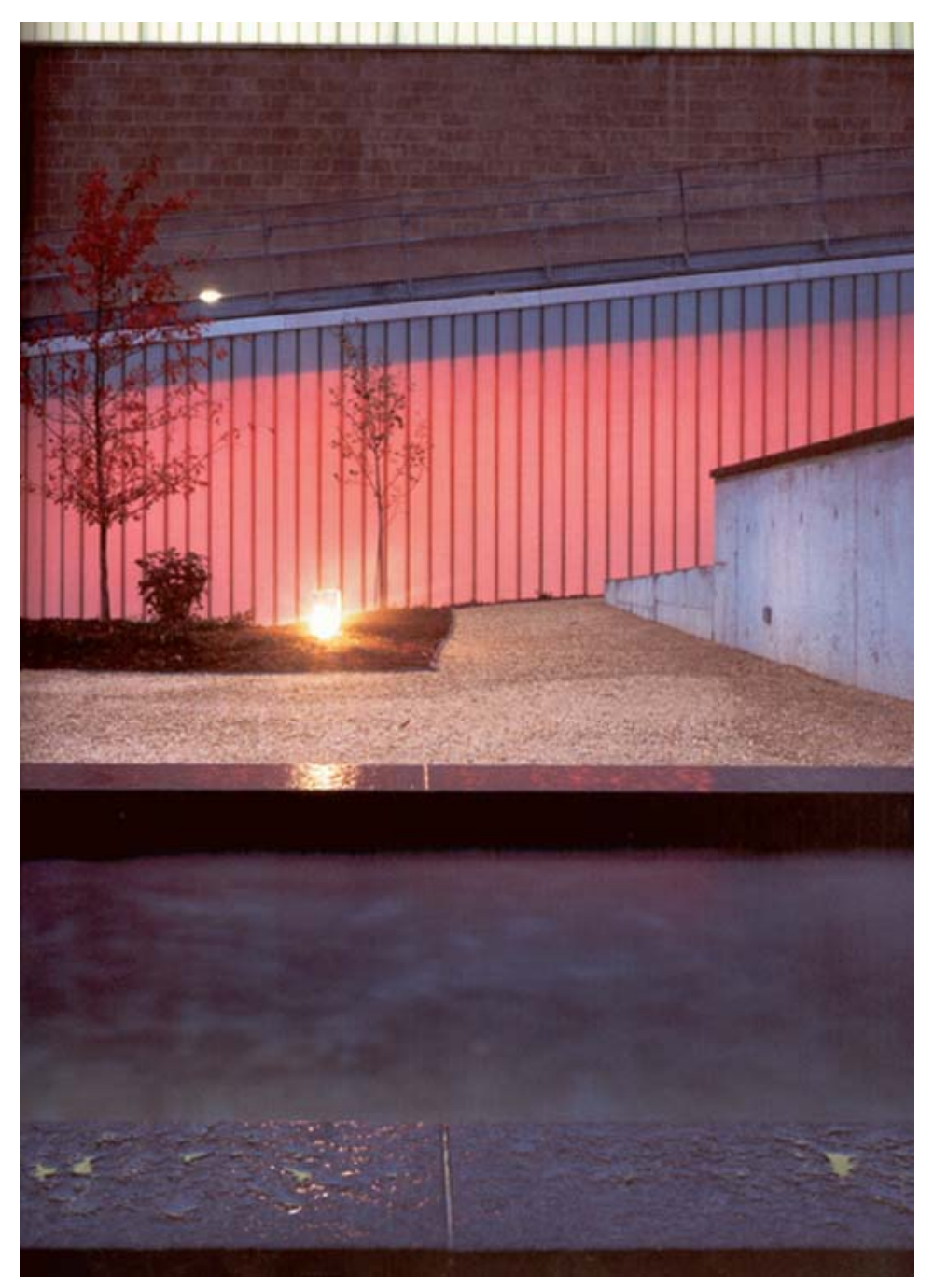

Figures 3.17. A haptic field of architectural phenomena: Addition to the Cranbrook Institute of Science, Michigan, 1992-98.

In his article "Corporeal Experience: A Haptic Way of Knowing” Maire Eithne O'Neill states that the term haptic can be described through multiple themes which are "the integration of many senses, such as touch, positional awareness, balance, sound, movement, and the memory of previous experiences." ${ }^{, 180}$ As O'Neill points out, in the haptic realm a network of sensations is signified, which are relevant for the realm of

\footnotetext{
${ }^{180}$ Maire Eithne O’Neill, September 2001, “Corporeal Experience: A Haptic Way of Knowing” in Journal of Architectural Education vol. 85 issue 1, p. 4.
} 
architecture as well. The experiential potential of architecture entails to stress on a haptic sensibility, in which all senses are activated.

When architectural phenomena are concerned, visual qualities designate, often, dominance over the others. In other words, sight is regarded as the primary sensation in experiential realm. Steven Holl puts forward a critical standpoint inquiring whether vision presents a sufficient experience of the materiality of the built environment or not. For him, a complete perception of architecture involves tactile experiences, as well as visual ones, which he explains as follows:

"The experience of material in architecture is not just visual, but tactile, aural, olfactory; it is all of these intertwined with space and our bodily trajectory in time. Perhaps no other realm more directly engages multiple phenomena and sensory experience than the haptic realm." 181

Here, lay the main idea underlining Holl's phenomenological approach to architecture; architecture is about perception, the sense of space, the texture of surface, and the effects of light, all signifying an experiential depth that is the main aspiration of architecture. The phenomena of architecture incorporate multi-sensory experiences within a unified realm. Architecture unifies multi-sensory experiences through its physical presence.

At this point, Holl approaches once again to Merleau-Ponty's phenomenological philosophy, in which the intercommunication of senses is emphasized as leading to a unified sense experience, intertwining the sense of touch and vision. ${ }^{182}$ Since visual perceptions are "inserted" into a "quasi-tactile field," says Merleau-Ponty, pure vision is not possible; yet, visual field is already charged with the sense of touch. ${ }^{183}$ To see a piece of wood, for instance, presupposes the experience of the texture of wood, synthesizing visuality with tactility. Merleau-Ponty states:

"The senses intercommunicate by opening onto the structure of the thing. One sees the hardness and brittleness of glass, and when, with a tinkling sound, it breaks, this sound is

\footnotetext{
${ }^{181}$ Op. cit. Holl, S., 1998 (first published in 1996), p. 16.

${ }_{182}$ Op. cit. Merleau-Ponty, M., 1962 (first published in 1945), p. 229.

${ }^{183}$ Ibid. p. 223.
} 
conveyed by the visible glass. One sees the springiness of steel, the ductility of red-hot steel, the hardness of a plane blade, the softness of shavings." "184

In the sense Merleau-Ponty puts forward, Juhani Pallasmaa, architect, points out that in haptic experience vision and tactility are synthesized. ${ }^{185}$ According to Pallasmaa hapticity can be described as "the unconsciousness of vision," in which "... vision contains an unconscious reading of surface texture, temperature and weight." "186 In Holl's approach to architecture, for whom a complete perception of architecture comprises multi-sensory experiences, we come across a haptic sensibility in the creation of an architectural work. This sensibility is influential in his understanding of architecture and making of spaces and forms.

For the architect, tactile experiences are primarily powerful in the perception of architecture. "The haptic realm of architecture is defined by the sense of touch," he states and explains further, "When materiality of the details forming an architectural space becomes evident, the haptic realm opens up." 187 The touch provides the body-subject with unmediated experiences of the built form. Bodily contact becomes the essential means tactile experience is acquired. As O'Neill points out, it is the "corporeal activity" that "allows us to know places in intimate, unself-conscious ways that visual sensibilities cannot describe." 188 Tactility enables to acquire a phenomenal identification of architectural work. For Steven Holl materiality and tactility reveal their consequences in architecture through determining spatial qualities. In his article "Within the City" he states:

"The space of a single room, like the vast space of a city, is defined by juxtaposition of matter. The stuff of which something is made has emotive motive. The transparency of a membrane, the chalky dullness of a wall, the glossy reflection of opaque glass and a beam of sunlight intermesh in reciprocal relationships, forming the particular phenomena of a place. Given an architectural idea, the relationships of construction materials impose a dimension that penetrates through matter to tactility. Matter interlocking with

\footnotetext{
${ }^{184}$ Ibid. p. 229.

185 Juhani Pallasmaa, 2003, "Thought, Matter and Experience" in El croquis, revised and extended edition (first published in Elcroquis issue 108 November/December, 2001), Mexico: Arquitectos Publishing, pp.48-69.

${ }_{186}$ Ibid. p. 65 .

${ }^{187}$ Op. cit. Holl, S., 1998 (first published in 1996), p. 16.

${ }^{188}$ Op. cit. O’Neill, M., September 2001, p. 4.
} 
perceiver's senses provides the detail that moves us beyond acute sight to tactility. From linearity, concavity and transparency, to harness, elasticity and dampness, the haptic realm opens." 189

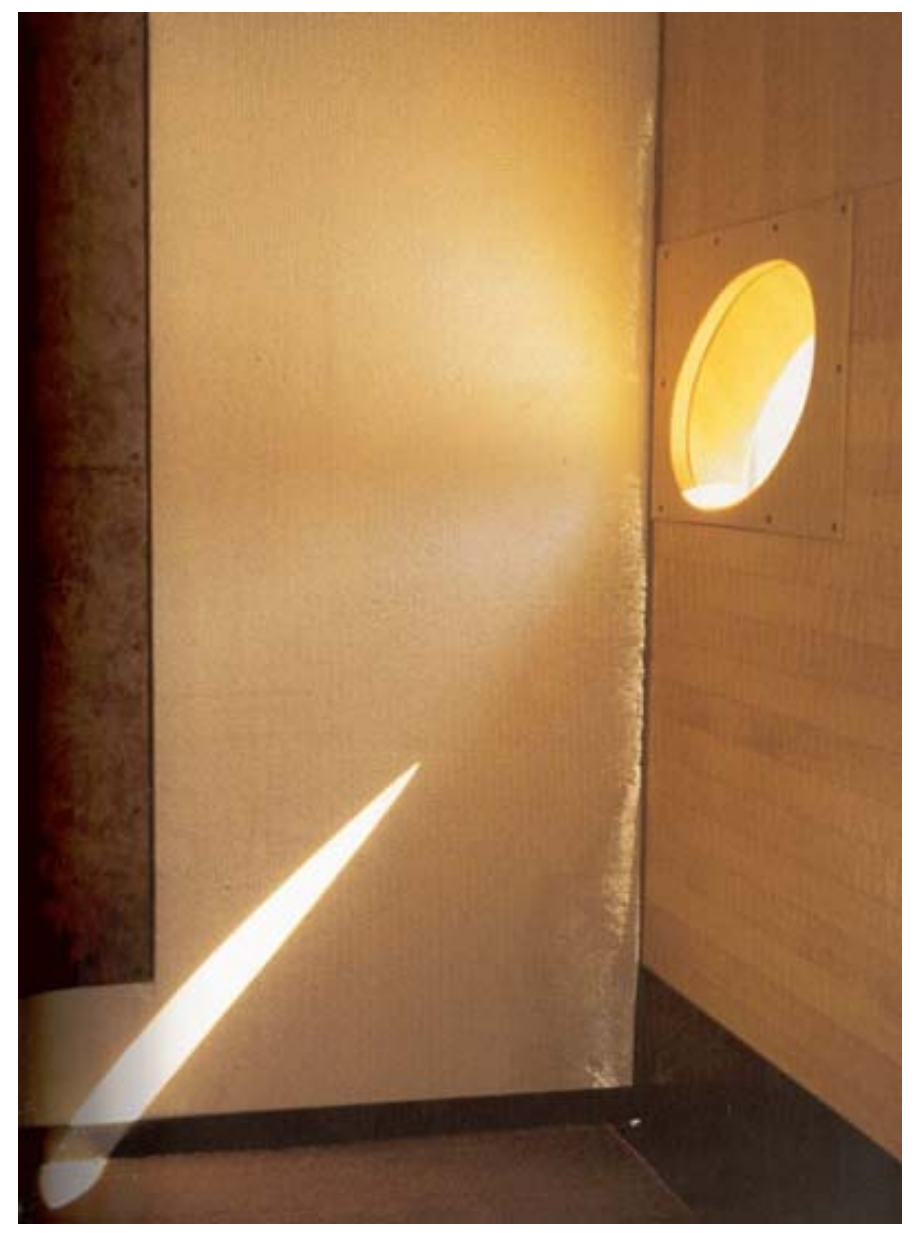

Figure 3.18. Tactile phenomena of architectural space: Chapel of St. Ignatus, Seattle, 199497.

In the chapel of St. Ignatus the phenomenal qualities of the built form, the metarial texture and the light effects on surfaces designate a haptic sensibility in articulating the spaces.

For the architect, the phenomenal properties of materials existing in place constitute a distinct phenomenal realm through which a distinct spatial character is brought into

${ }^{189}$ Steven Holl, 2003, "Within the City" in El croquis, revised and extended edition, Mexico: Arquitectos 
being. The material characteristics of a place and our haptic perceptions are essential for the way place can be conceived. In his article O'Neill points out that the "phenomenological understanding" of environment primarily depends on our tactile experiences: "People gain environmental understanding from tangible physical experience, from coming in contact with natural and built environments..."190

At this point it is necessary to focus mainly on three themes that will help one better understand how materiality can be the means to identify a place. First of all, Holl focuses on the essence of material, which he describes as "the chemistry of matter." Furthermore, for him there is a sensational dimension in tactility that is related not only to emotive insights of the subject, but also to the emotive presence of matter. Thus, the emotive content of architecture resides in the reciprocal relationship between the subject and the material world, established by means of haptic experiences. For the architect, materials, produces psychological effects motivating a psychological dimension in hapticity.

\subsubsection{1. “Chemistry of Matter” and Haptic Psychology}

According to Merleau-Ponty, sense experiences enable us to explore the nature of any object, which he explains as follows:

"The form of objects is not their geometrical shape: it stands in a certain relation to their specific nature, and appeals to all our other senses as well as sight. The form of a fold in linen or cotton shows us the resilience or dryness of the fiber, the coldness or warmth of the material." 191

As the philosopher mentions "the specific nature of objects," Steven Holl puts emphasis on the essence of material in architecture, using the term "chemistry of matter." The "chemistry of matter" indicates the essence of material beyond its physical properties or function. ${ }^{192}$ It is, rather, the means material exists as matter; it is the means by which wood is wood, paper is paper, or silk is silk, within their intrinsic qualities that define

\footnotetext{
Publishing, p.87.

${ }^{190}$ Op. cit. O’Neill, M., September 2001, p. 4.

${ }_{191}$ Op. cit. Merleau-Ponty, M., 1962 (first published in 1945), p. 229.

${ }^{192}$ Op. cit. Holl, S., 2000, p. 68.
} 
them. "Chemistry of matter" can be described through the way material creates an intrinsic meaning equivalent to its presence.

Emphasizing on essences, Holl investigates the poetic content of matter. The architect focuses on the emotive effects of materials on subjects, which for him is related to the "depth" or "mood" of materials, once again approaching to the phenomenological philosophy of Bachelard. As Bachelard attributes objects emotional contents, for instance wardrobes, shelves, desk, for instance, are described as "veritable organs of the secrets of psychological life," ${ }^{193}$ Holl mentions that material quality of objects signifies particular "moods" that unfold in their psychological effects on the subject.

For the architect there exists a poetic depth in the experience of matter. This poetic depth depends on the imagination of the subject and the psychological effects of matter. Architectural perceptions activate imagination of the perceiver. Thus, Holl states that our perceptual experiences not only is related with the physicality of the matter, but also includes a poetic and imaginative depth, which in turn constitute the psychological dimension of the realm of architecture. Holl explains this as follows:

“...Parallel to the emotive aspect of poetry, the emotive side of human nature is aroused by proportions and the tactile dimension. Initial concept provides the intellectual dimension that is given emotive form in material and detail. This relationship in a work establishes an emotional tie, in a psychological sense, to the experience of architecture." 194

Steven Holl states that tactile qualities create psychological effects in experiencing the architectural work, which goes beyond any intellectual construction. The physical contact established through the sense of touch depends on "corporeal" experience of the subject, occurring through emotive and sensational motives. In Holl's approach to architecture, hapticity is ascribed psychological and sensational attributes.

${ }^{193}$ Op. cit. Bachelard, G., 1969, p. 78.

${ }^{194}$ Op. cit. Holl, S., 2003, "Within the City”, p. 87. 
He states: "From meditative spaces to inspiring details, architecture holds the potential to change the way we live." ${ }^{195}$ Thus, our haptic experiences in the architectural realm are influential in the way we perceive the world. Opening towards a phenomenological perspective, he considers that hapticity becomes an internal part of our lives. Approaching to the consideration of inherent connection between the essence of existence and our sensational perceptions of the world in Merleau-Ponty's phenomenology, in Holl's architecture an existential relation between our haptic perceptions and life is signified. According to Merleau-Ponty, the object of sensation posses "a certain rhythm of existence;" that is to say, through the existence of the sensible, the significance of existence is brought into being. ${ }^{196}$ The philosopher mentions that "qualities" of the sensible objects, "radiate around them a certain mode of existence," which provides the sentient subject conceiving the meaning of existence. ${ }^{197}$

"The essence of material, smell, texture, temperature and touch," says Steven Holl, "vitalizes everyday existence." ${ }^{198}$ For the architect material is the fundamental element of architecture signifying an existential condition. This existential condition is the perceptual situatedness of human beings into the world. The materiality of architecture becomes a medium through which we are perceptually connected to the world around us. Thus, matter internally connects architectural experience with the notion of being. As we live in the built environment, our lives become configured through the materiality of architecture.

Perceiver's relation to "the rhythm of existence," which is presented through the essence of material, is via our haptic perceptions. As Pallasmaa suggests, hapticity allows us to establish an intimate connection within the world. The internal link between the sentient subject and the sensible material is established on the basis of hapticity, which he

\footnotetext{
${ }^{195}$ Op. cit. Holl, S., 1993, “Dwellings", p. 43.

${ }^{196}$ Op. cit. Merleau-Ponty, M., 1962 (first published in 1945), p. 213.

${ }^{197}$ Ibid. p. 214.

${ }^{198}$ Op. cit. Holl, S., 2000, p. 68
} 
mentions as follows: "The world becomes part of ourselves, and we become part of the world primarily through haptic identification." 199

The content of our haptic experiences incorporate the material essences and the perceiver's sensational engagement with the essence of material. While the use of materials, details, colors, light, and shadow in architecture form the distinct qualities of a place, through our haptic perceptions of them, architectural space is identified, configuring human life. For Holl, the quality of living is affected by the phenomena of architecture, which he explains as follows:

"In material and detail, an intensity of quality, not quantity, stimulates the perceiver's senses, reaching beyond acute sight to tactility, reviving the haptic realm The joy of living, and the enhanced quality of everyday life is argued in a quality of architecture. It is whispered in material and detail and chanted in space."200

According to the architect, due to its emotional content materiality is an essential attribute of our architectural experiences. Therefore, architecture becomes "catalyst" for shaping our everyday experiences, through which the ultimate power of architecture is made manifest. $^{201}$

\subsubsection{Haptic Sensibility as a Resistance to the Loss of Experiential Depth}

The haptic sensibility of Holl provides him with achieving a particular thinking and making of architecture enabling to distinguish his work from many other practices. In Holl's phenomenological approach to architecture a haptic resistance becomes characteristic of his work.

Holl primarily puts emphasis on the movement of body in space, tactile and visual experiences, smell, sound, the multi-sensory qualities of architecture that are made manifest. In this way he develops a resistance against the visual impact of information

\footnotetext{
199 Op. cit. Pallasmaa, J., 2003, p.65.

${ }^{200}$ Steven Holl, 1993, “The Haptic Realm” in The Steven Holl Catalogue, Zurich: Artemis and ArcenReve Centre d'Architecture, p.31.

${ }^{201}$ Op. cit. Holl, S., 2000, p. 71.
} 
and communication technologies within contemporary architectural practices, which for him lacks the power to exhibit the experiential potential of the architectural field.

The way haptic sensibility establishes a resistance against the dominance of visuality in architecture is due to the sense of touch that is presented through tactility. Touching has the capacity to embody experiences that cannot be transmitted merely through vision.

At this point Kenneth Frampton's criticism of the overemphasis on visual aspects in universal technologies, gains importance. Frampton points out the primacy of tactility as the essential means of acquiring a phenomenological understanding of a place, emphasizing that:

"...the liberative importance of tactile resides in the fact that it can only be decoded in terms of experience itself: it cannot be reduced to mere information, to representation or to the simple evocation of a simulacrum substituting for absent presence."202

For Frampton, tactile experiences provide the subject with being intimately connected to the built environment through perceiving and comprehending the experiential power of an architectural work.

Similarly, for Holl meaning in architecture can be conveyed through our haptic experiences of the built form. The haptic experiences in architecture incorporate the sense of touch, movement, sight, smell, and sound. Approaching to Frampton's criticism about the insufficiency of visual experiences in architecture, architect Juhani Pallasmaa emphasizes that, hapticity offers an unmediated, experiential connection between subject and built work, promoting "intimacy, interiority and nearness as opposed to the experience of distance, exteriority and control projected in today's architecture obsessed with the visual image.",203

Holl looks for "the intimacy, interiority and nearness of haptic experiences in architecture. He critically emphasizes that the scenographic impact of communication

${ }^{202}$ Kenneth Frampton, 1989 "Towards a Critical Regionalism: Six Points for an Architecture of Resistance," The Anti-Aesthetic. Essays in Post-Modern Culture, ed. H. Foster, Port Townsend: Bay Press, p. 28. 
technologies in architecture, fail to exhibit the experiential potential of architecture, leading to the loss of experiential depth. He describes the current problematic of the overemphasized concern on scenographic qualities in contemporary architectural practice as follows:

"Many of the problems in today's built environment are due to the automobile. The speed of the world today has produced an architecture that has become an art of the printed image fixed by the hurried eye of the camera. The gaze flattens the image into a picture and it loses plasticity. Instead of experiencing our being in the world, we look at it as spectators and thus create a world devoid of authenticity of material and tectonic logic. Today's architectural practice has also affected the perceptions and meaning of space. The industrial and commercial forces at work on the "products" for architecture tend toward the synthetic. Wooden casement windows are delivered with weatherproof plastic vinyl coverings, metals are anodized and coated with false outer surfaces, tiles are glazed with colored synthetic coatings, and wood grain is simulated. The sense of touch is dulled or concealed with these commercial industrial methods, as is the texture and essence of material and detail displayed." 204

While the velocity and the scope of information technologies provide limitless flux of information visually linking various parts of the world in few seconds, the distinction between space and time, says Holl, becomes blurred. Within the blur in space and time particularity, the primacy of human body in the realm of architecture is ignored, leading to what Enrique Norten calls "disembodied architecture.",205

For Holl, the material qualities help to identify matter and built environment. The essence of architecture, for him, resides in its multi-sensory perceptual capacity, which penetrates our phenomenological understanding of architecture.

\footnotetext{
${ }^{203}$ Op. cit. Pallasmaa, J., 2003, p. 63.

${ }^{204}$ Op. cit. Holl, S., "Phenomenology", [Internet, WWW], ADRESS: http://www.arch.uiuc.edu/thesisstudio/tgs/history-3.htm [Accessed: 30 June 2003].

${ }^{205}$ Enrique Norten, 1997, "Immaterial Architecture" in Anybody, Cynthia Davidson (ed.), New York: Anyone Corporation, p. 195. In his article Norten puts forward a critical perspective towards universal architectural practices in the new era, critically mentioning: "A new era in which information is the central protagonist has replaced the age of heroic modernism. This new universal culture based on the flow of capital, the exchange of goods and consumerism in a free global market has precipitated a total technological homogenization and given meaning to the phrase of global village. Furthermore, a complex network of information now connects place and cultures in a continuous time and space, creating uniformity of values and ideas." Ibid. p.191. Due to our changing understanding of values and ideas, argues Norten, our architectural understanding and conception involve "disembodied" relations without emphasizing either the particularity of places or the presence of perceivers.
} 


\title{
CHAPTER 4
}

\section{IN SEARCH OF THE ARCHITECTURAL EMBODIMENT THROUGH A PHENOMENOLOGICAL APPROACH}

\begin{abstract}
Kenneth Frampton denotes two main characteristics of Steven Holl's architecture as follows: "Anchoring" as a topological strategy, and "intertwining" as "integrating the conceptual level of his work with a phenomenological experience of its presence."206 Through "anchoring," Holl points out a state of being fixed where a connection between building and its site is proposed, while searching for the phenomenal potential of a concept, as the departure point of his designs.
\end{abstract}

While forming the conceptual ground of the architectural design, articulating spaces and forms, and then, building the architectonic form, the realm of phenomena is the basic ground the architect starts with. Holl creates his own context through a phenomenological framework aiming at "intertwining" idea with phenomena, intangible with tangible, concept with feelings. Furthermore, his architecture has a tectonic distinctness that depends on the way he makes architecture, his material use, his design of details, and applied structural technology.

In this final part of the thesis, it is aimed to trace the phenomenological framework of Steven Holl's architectural thinking through his architectural practice, by examining his particular projects. In doing this, it is proposed to unfold the way he translates a particular phenomenological philosophy into the realm of architecture.

\footnotetext{
${ }^{206}$ Kenneth Frampton, 1989, “On the Architecture of Steven Holl” in Anchoring, New York: Princeton Architectural Press, p. 8.
} 


\subsection{From Concept to Architectural Form}

Steven Holl defines concept as follows:

"A concept is the engine that drives the design process. Early in each project, after analyzing the site and program and sometimes after several false starts, a central concept (or concepts) is settled on, together with vague spatial sketch. As each site circumstance is unique, we aim for equally balanced and particular solutions. The concept, expressed in the diagram and words, helps focus a manifold of different aspects. It helps in the development of project..." 207

In starting a design, the architect's focus on site, situation, and program offers a field of examination wherein the possibility of different starting points is introduced. As Holl concentrates on a project, a particular concept emerges, outlining of the architectural design. In each design, the emergence of a concept is set forth within the watercolor spatial and perspective sketches where the architect searches for the phenomenal and experiential potential of the concept. At this point, Holl's concept diagrams present an operative tool not only exhibiting the underlining idea of the design, but also generating new conceptions, through which various possibilities for architectural design are elaborated. He describes the concept diagram as follows:

"I consider them [concept diagram] my secret weapon. They allow me to move afresh from one project to the next, from one site to the next... Finding an initial concept for each project that captures the essence of the architectural opportunities unique to that project is, for me, the only way into it, the door through which new ideas enter architecture." ${ }^{208}$

The architect works with concept diagrams as the articulation of an indeterminate idea into a more definite concept. Clarifying the organizing idea, the concept diagram is the medium through which a network of relations is set forth. It provides the ground for the design of further spatial organizations and material qualities.

Focusing on Steven Holl's particular projects, it is aimed to examine how an idea emerges, how it develops into a concept, and then, how the concept is transformed into

\footnotetext{
${ }^{207}$ Op. cit. Holl, S., in Pallasmaa, J., 2003, p. 58.

${ }^{208}$ Op. cit. Holl, S., in Kipnis, J., 2003, p.36.
} 
architectural spaces and forms. The architectural conception process and articulating them into buildings will be the main issues of this section. While conception process will be examined in relation of the philosophical references the architect puts forward, a focus on his particular projects will allow us to observe how they generate Holl's architectural practice.
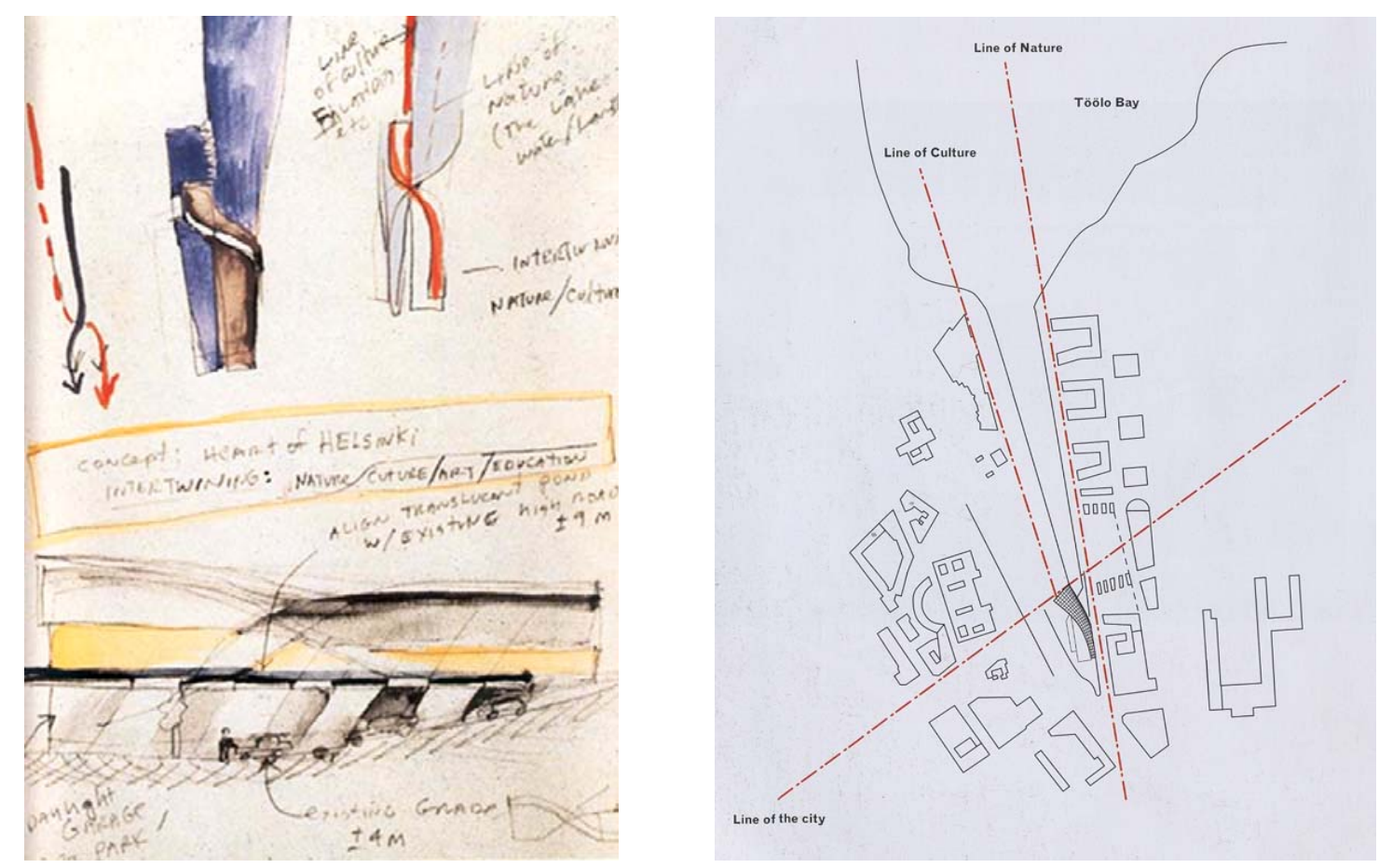

Figure 4.1. The concept sketch of Helsinki Museum of Contemporary Art, 1993-98. Figure 4.2. "Lines of forces" in the museum design.

When Helsinki Museum of Contemporary Art is examined, it is observed that MerleauPonty's philosophical concept of "chiasm," or "intertwining," constitutes the philosophical reference of architectural design. Holl's museum design develops through a conceptual strategy deriving from the "chiasmatic" relationship between the body and the world, in the sense Merleau-Ponty suggests. ${ }^{209}$

\footnotetext{
${ }^{209}$ Merleau-Ponty explains the chiasmatic relationship between the body and the world with reference to the term "flesh." He describes "flesh" as "an element of Being" or "the formative medium of the object and the subject" through which both the body and the world is constituted. His conceptions of "intertwining",
} 
In achieving his concepts, Holl is inspired by situation that can be generated either from the physical references of site or from historical, mythical, or religious themes, as the context of architectural design. Besides he defines a particular situation through the intrinsic references of a project; his re-interpretation of program and the content of the building may be the departure point of Steven Holl's designs. In this project, the situation derives from the physical site of the museum wherein the philosophical reference of chiasm is meant to exhibit the intertwined relation of building within the city.

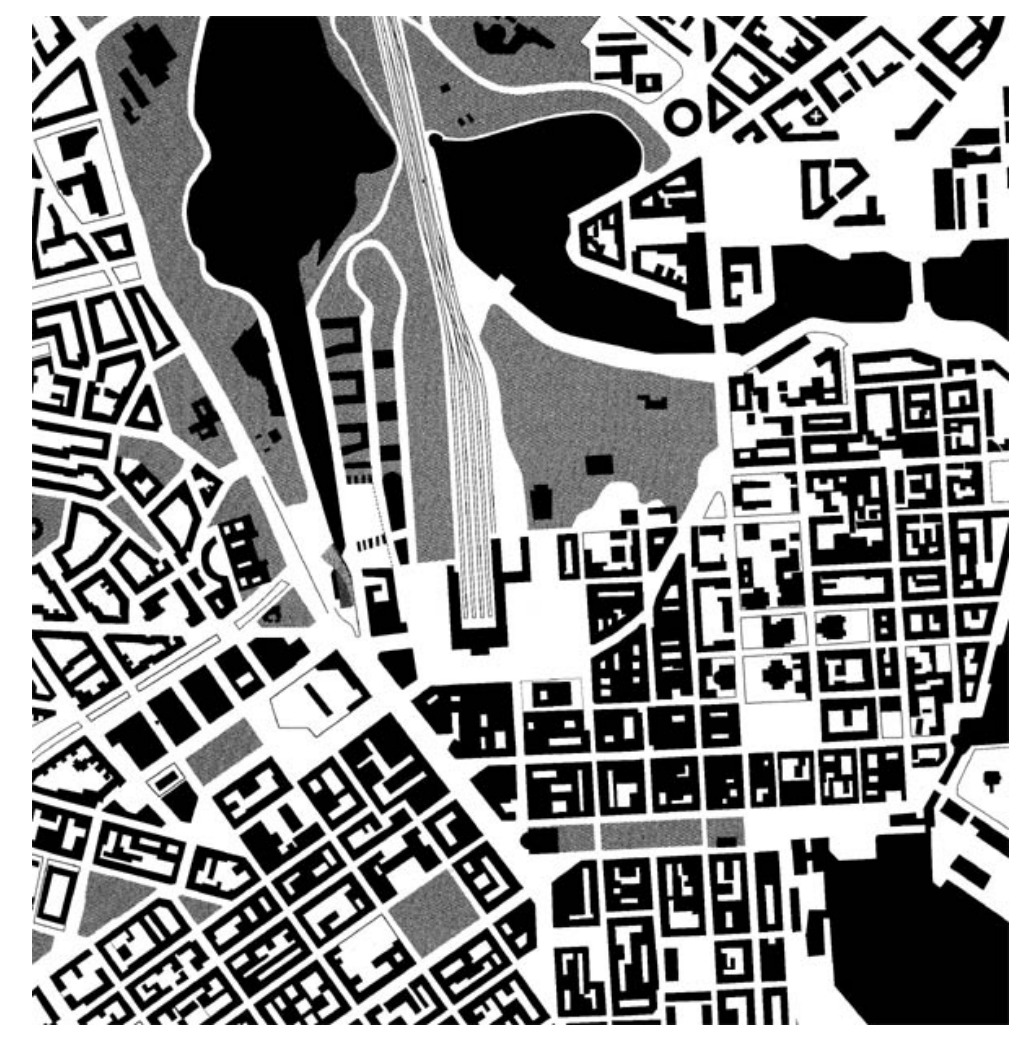

Figure 4.3. Site Plan: Helsinki Museum of Contemporary Art, 1993-98.

\footnotetext{
"chiasm" and "flesh", all designate the primordial condition of existence of both body and the world. Op. cit. Merleau-Ponty, 1968, pp. 138-139.
} 


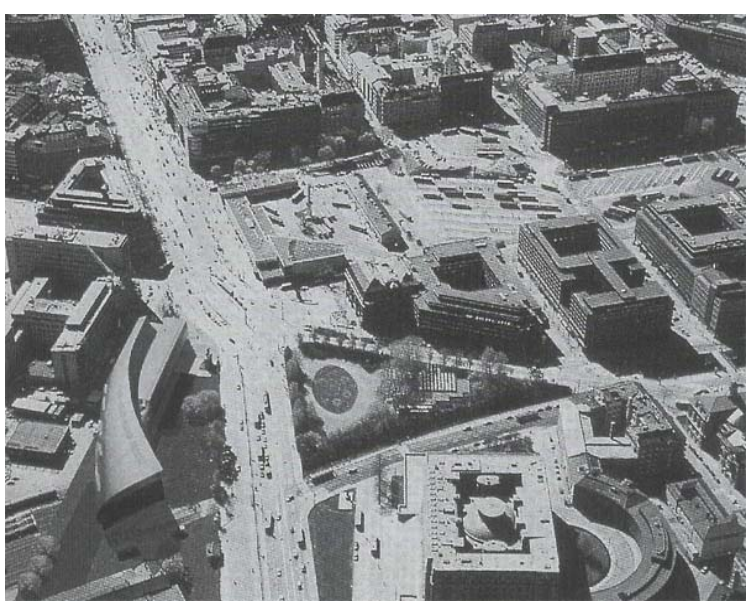

Figure 4.4. Photomontage of model in site.

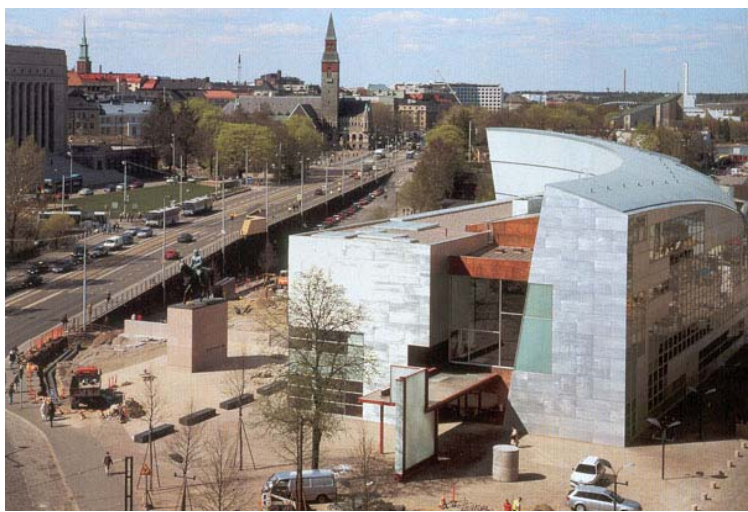

Figure 4. 5. Entrance façade of the museum.

The site of the museum is located in an area where the Töölo Bay narrowly meets the land. The architect concentrates on the focal location of the site and assigns two main lines of forces, which he describes as "cultural line" and "natural line." These assigned forces of the site derive, indeed, from the architect's subjective interpretation of the situation, which he mentions as follows:

"A kiasma occurs as the building's mass intertwines with the geometry of the city and landscape, which are reflected in the shape of the building. An implicit 'cultural line' curves to link the building to Finlandia Hall while it also engages a 'natural line' connecting to the east landscape and Töölo Bay."210

${ }^{210}$ Op. cit. Holl, S., 1998 (first published in 1996), p. 88. 
As he mentions above, the philosophical conception of chiasm defined by Merleau-Ponty exhibiting the "reciprocal insertion" of the body into the world, inspires Holl in the formal articulation of the building with an analogy of "two hands clasping each other."211 A rectangular form is inserted into a curved one, constituting the overall intertwined geometry of the museum building. Besides such a formal analogy, the intertwining of "natural and cultural lines" within the museum signifies a conceptual analogy.

In designing the museum, Steven Holl dwells upon "an escape from the dualities of body/thing and man/nature." ${ }^{212}$ With the concept of 'duality', the presence of two entities as distinct realms is implied. While Holl rejects the presence of such a duality, he suggests the interdependence between nature and culture. His museum design depends on a kind of an insertion wherein the building becomes a focal point that joins artistic and educational facilities under its formal presence. Holl states:

"With Kiasma, there is a hope to confirm that architecture, art, and culture are not separate disciplines but are all integral parts of the city and the landscape. Through care in development of details and materials, the museum provides a dynamic yet subtle spatial form, extending towards the city to the south and the landscape to the north. The geometry has an interior mystery and an exterior horizon that, like two hands clasping each other, form the architectonic equivalent of a public invitation. The interiors refer to the landscape and form the site that, in this special place and circumstance, is a synthesis of building and landscape... a kiasma." 213
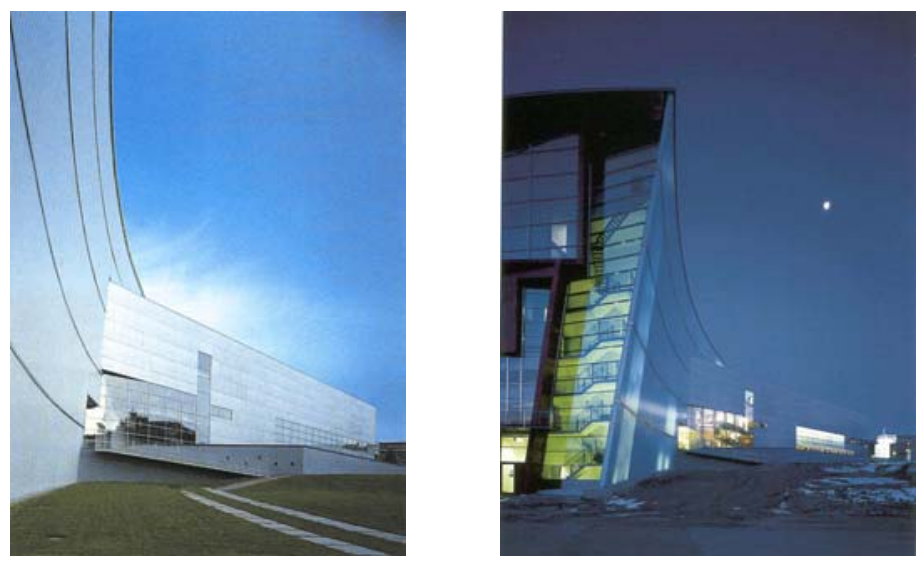

Figures 4.6. and 4.7. Looking for the architectonic embodiment of the "chiasm": Helsinki Museum of Contemporary Art, 1993-98.

\footnotetext{
${ }^{211}$ Ibid. p. 90.

${ }^{212}$ Op. cit. Holl, S., 2000, p. 38.

${ }^{213}$ Op. cit. Holl, S., 1998 (first published in 1996), p. 90.
} 
In the design of the Helsinki Museum of Contemporary Art, Holl's conceptual strategy effectively depends on "chiasm," which is a philosophical concept. Referring to the intertwined relation between the body and the world, the architect aims at integrating architectonic form into landscape and the existing city fabric. Holl proposes an architectural conception of "the chiasmatic interplay of culture with nature," As Kenneth Frampton calls it. ${ }^{214}$ Besides achieving such a formal intertwining, Holl brings forth a programmatic intertwining in the museum design. For Holl the program of a museum should embrace cultural, artistic and architectonic qualities within one integrated whole. While the conceptual strategy of the architect is based upon creating such a whole, Merleau-Ponty's concept of "chiasm" gives the name of the museum as Kiasma, demonstrating the philosophical reference of the architect.

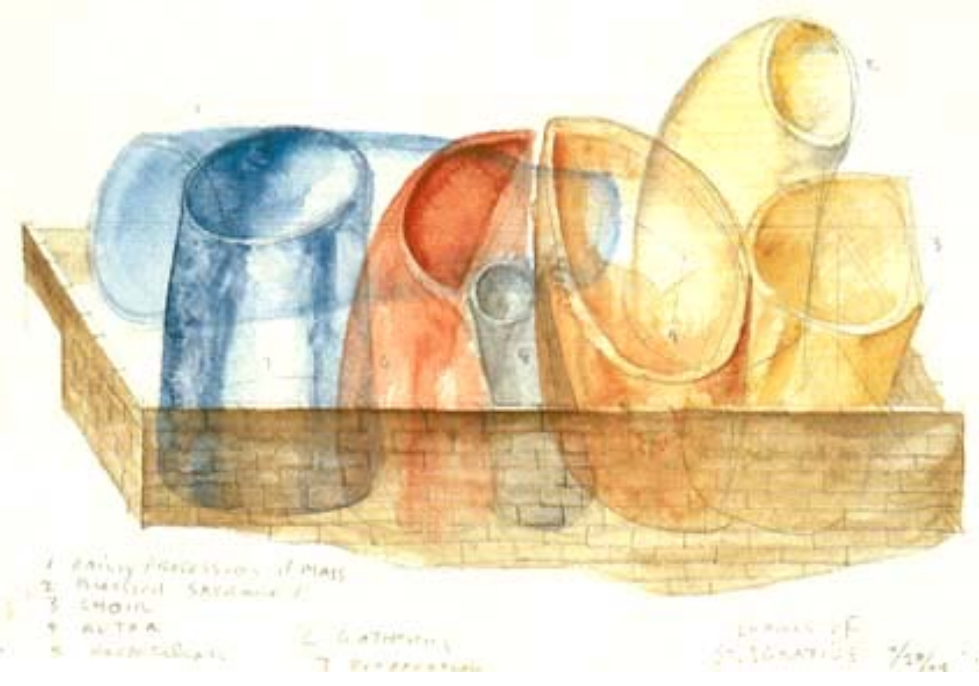

Figure 4.8. Concept sketch of "Seven Bottles of Light in a Stone Box": The Chapel of St. Ignatus, Seattle, 1994-97.

In the Chapel of St. Ignatus, we find a similar conceptual strategy. However this time Holl achieves his concept by re-interpreting the program, which he explains as follows:

${ }^{214}$ Op. cit. Frampton, K., 2003, p. 540. 
"The metaphor of light is shaped in different volumes emerging from the roof whose irregularities aim at different qualities of light. The concept, a gathering of different lights, can be seen in the concept of sketch of bottles emerging from a stone box. Just as no single method is prescribed in the Jesuit's spiritual exercises, here a unity of differences is gathered into one." 215

Here, in achieving a conceptual base in the design, the concept acts as an image-making tool. Holl tends to express the concept he works with both verbally and visually through presenting an image. This image includes some architectural clues; that is to say, Holl's form and space making occur with reference to the image he puts forward. Accordingly, in his design process, first, the concept leads to an image; then, this image becomes a design vehicle guiding the articulation of the spaces and the form.
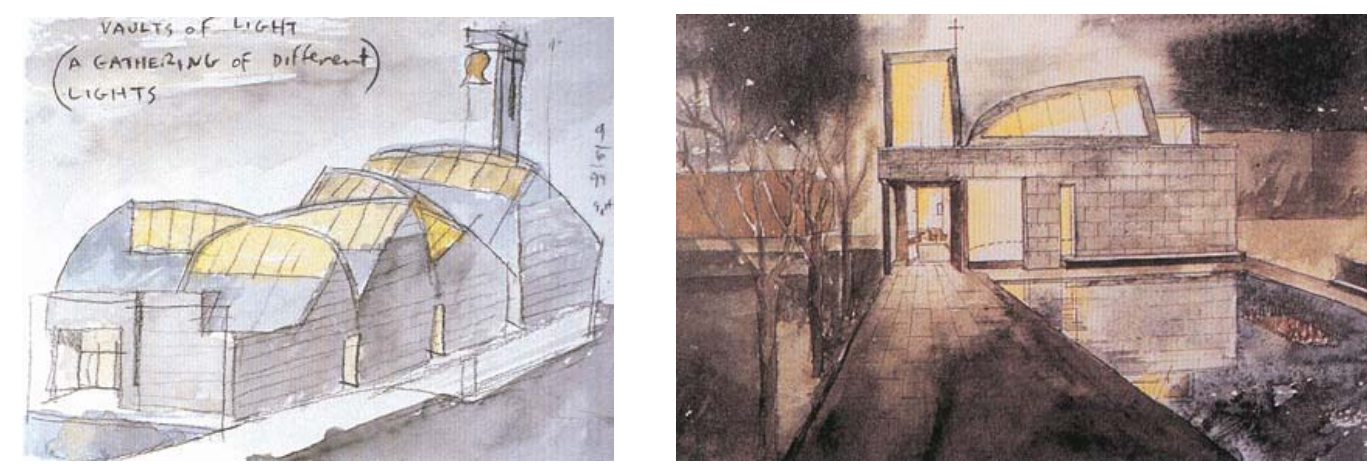

Figures 4.9 and 4.10. Watercolor sketches of the chapel.

With the watercolor sketch of "Seven Bottles of Light in a Stone Box," Steven Holl brings forth the visual and verbal expression of the concept he introduces. This is a noticeable example to understand the architectural transformation of an image into spaces and forms in Steven Holl's architecture. Beyond being a metaphorical manifestation of a religious theme, bottles of light are then articulated into roof tectonics. The brutal expression of the building, on the other hand, resembles the stone box in Holl's sketch.

In developing the concept of "gathering of different lights," Holl concentrates on the spiritual themes of Christian religious tradition. It is not coincidental that the chapel as a place for worship is designed on the basis of a religious concept. Holl strives for

${ }^{215}$ Op. cit. Holl, S., 1998 (first published in 1996), p. 158. 
articulating particular themes of Jesuit order, through architectural forms and spaces. In other words, he puts forward a transformation of spiritual themes into the architectural realm.

In order to do this, he particularly focuses on the spiritual discourse of St Ignatus who deals with seven themes of Jesuit order and light that he himself affirms as a metaphor through which these themes are exhibited. Denoted as "Procession", "Nartex", "Nave", "Blessed Sacrament", "Choir", "Altar", and "Reconciliation" these particular religious exercises are meant to guide the spatial organization of the chapel. ${ }^{216}$ The spiritual depth of architectural design is made manifest through the conceptual schematization of "seven bottles of light in a stone box," where each bottle, says the architect, corresponds to distinct parts of Jesuit rituals. As Annette Le Cuyer mentions, Holl's design of St Ignatus Chapel presents "a built metaphor of spiritual life," wherein a spiritual illumination is suggested to be created through the reflections of light. ${ }^{217}$

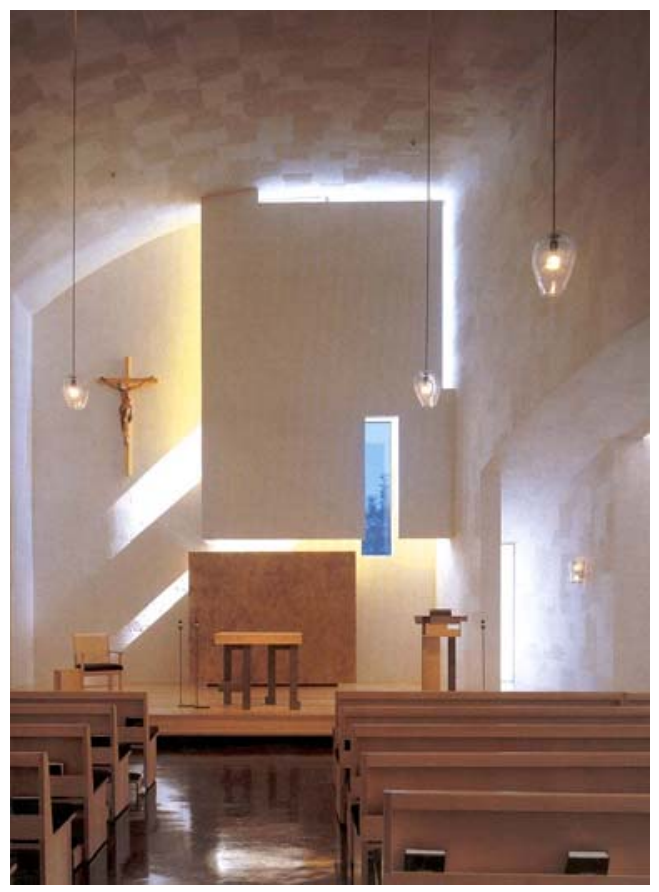

Figure 4.11. The “Altar”: The Chapel of St. Ignatus, Seattle, 1994-97.

\footnotetext{
${ }^{216}$ Op. cit. Holl, S., 2003, El croquis, p.280.

${ }^{217}$ Annette Le Cuyer, July 1997, "Congregation of Light" in Architectural Review volume 202 issue 5, p.28.
} 

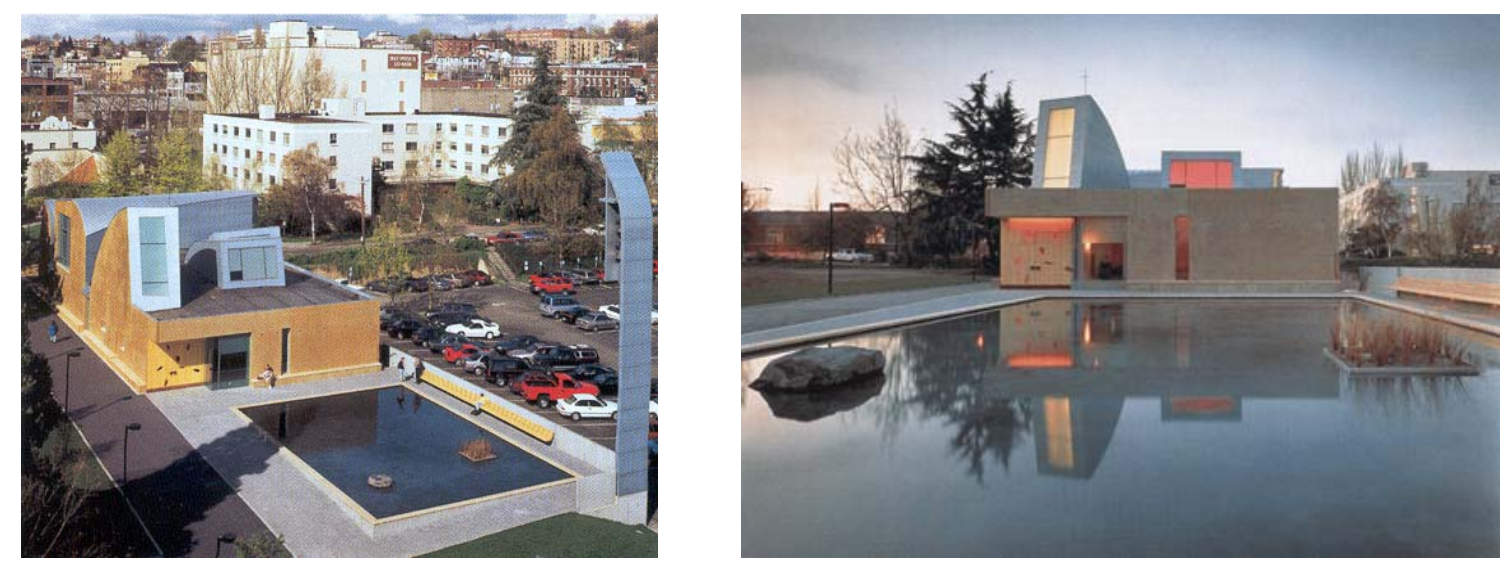

Figure 4.12. The irregular roof tectonic with "vaults of light" Figure 4.13. Light reflections over the "thinking pool": The Chapel of St. Ignatus, Seattle, 1994-97.

Starting with the concept of light as a conceptual reference, the roof has a unique tectonic with seven asymmetric and irregular light towers. The differently colored lenses located on the unique roof tectonics produce varying light effects through interior spaces of the chapel. Thus, the interior space becomes divided into distinct compartments, not by means of walls, but of light, shadow and color.

Holl's focus on Jesuit ritual produces "a field of inquiry" for the chapel design. Dealing with this particular territory of investigation, "a focus and limit" is set forth. The emergence of a particular concept provides the initial propositions from which the design develops further. The stated concept sets the structuring frame of architectural design where the architect aims at material and spatial embodiment of the concept.

As distinct from the content-based conception of the Chapel of St. Ignatus project, in the Simmons Hall project, in achieving the concept of "porosity" Holl refers to the physical condition of the site, which does not seem to be philosophical at the first glance. Starting from a physical concept, the architect aims to create an experiential depth in the undergraduate residence. He explains the idea that lies behind porosity as follows: 

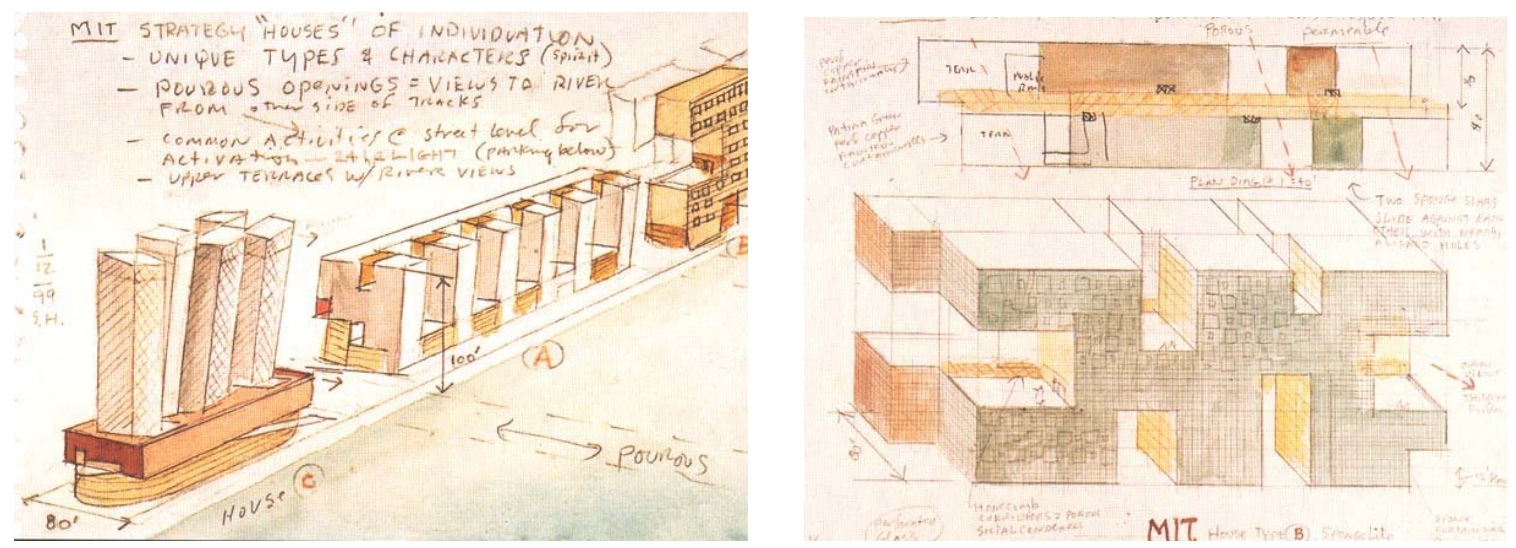

Figures 4.14 and 4.15. "Urban Porosity" as the central concept of the design: Simmons Hall, Massachusetts, 1999-2002.

"Porosity can be a new type of being. Its potentiality of consciousness indicates an opening where the horizon is included within it. We hope to develop the possibility of a collection of things held together in a new way where the "horizon" is open and merges with both exterior and interior."$" 218$

While porosity offers a conceptual base, the architect inquires its phenomenal exposition. Porosity associates with continuity, permeability, and the potential of a visual interaction between interior and exterior. As Holl states above, he works with horizon included in porosity, through which a permeable and continuous situation is defined. His design of the undergraduate residence involves an examination of the phenomenal potential of porosity, where the architectonic form, spatiality and material qualities are designed in a way to exhibit this potentiality.

Simmons Hall is designed as part of a design competition held within an expansion program for the MIT campus. In the competition, Steven Holl introduced four distinct designs along the Vassar Street at MIT, among which Simmons Hall is constructed. Having described the concept of porosity as an overall conceptual strategy, all of these designs display a fragmented structure in different manners. Yet, in designing all buildings, the common ground he starts from is a desire of creating "urban porosity,"

${ }^{218}$ Op. cit. Holl, S., 2000, p.305. 
where he works with porosity as a morphological concept. ${ }^{219}$ In his morphological study, he avoids building a solid barrier; instead, the architectonic is meant to provide permeability and visual continuity, within the urban fabric and the Charles River, next to the MIT campus. $^{220}$

The concept Holl achieves with reference to the physical conditions of the site generates an indeterminate image in his intellect whose visual response is presented as a horizontally sliced sponge. Serving as a design vehicle, sponge image is followed by a conceptual diagram where pores are regarded as offering "force fields of energy."221 This metaphorical use of sponge becomes his departure point in articulating spaces; pores correspond to spaces with diverse functions such as entrance hall, auditorium, lounge or rooms.
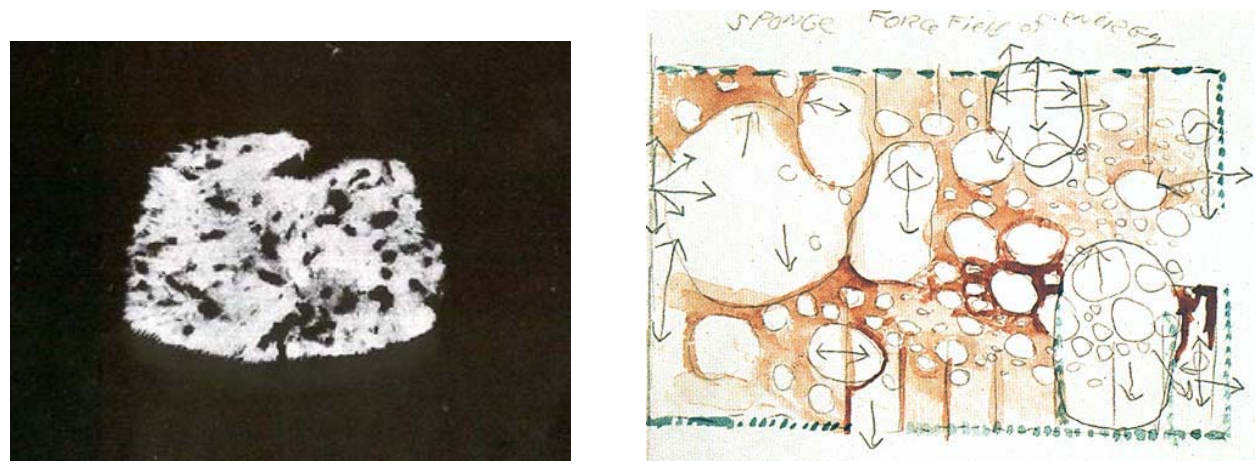

Figures 4.16 and 4.17. The metaphor of sponge as a tool for image making: Simmons Hall, Massachusetts, 1999-2002.

Holl describes his reference of sponge in architectural design as follows:

"The sponge concept for the new Undergraduate Residence Hall transforms a porous building morphology via a series of programmatic and bio-technical functions. The overall building mass has five large-scale openings. These roughly correspond to main entrances, view corridors, and the main outdoor activity terraces of the dormitory

\footnotetext{
${ }^{219}$ Ibid. p. 308.

${ }^{220}$ Sarah Amelar, "Steven Holl experiments with constructed...." In Architectural Record vol. 191 issue 5, p. 205.

${ }^{221}$ Op. cit. Holl, S., 2000, p. 304.
} 
connected to programs such as gymnasium. The next scale of opening creates vertical porosity in the block with a ruled surface system freely connected to sponge prints, plan to section. These large, dynamic openings (roughly corresponding to the houses in the dorm) are the lungs of the building bringing natural light down and moving air up through the section." 222

Investigating the phenomenal and experiential potential of the concept, the architect focuses on the visual continuity and permeability provided through porosity. The structural attributes, the spatial formation and the material qualities of the building derive from porosity, yielding an overall conceptual strategy of architectural design. While the perforated façade structure is like a permeable layer, the architect created horizontal and vertical porosity both within plans and sections. There are amorphous openings on the rectangular plan, which exhibit horizontal porosity, and are vertically connected leading to a vertical porous formation.
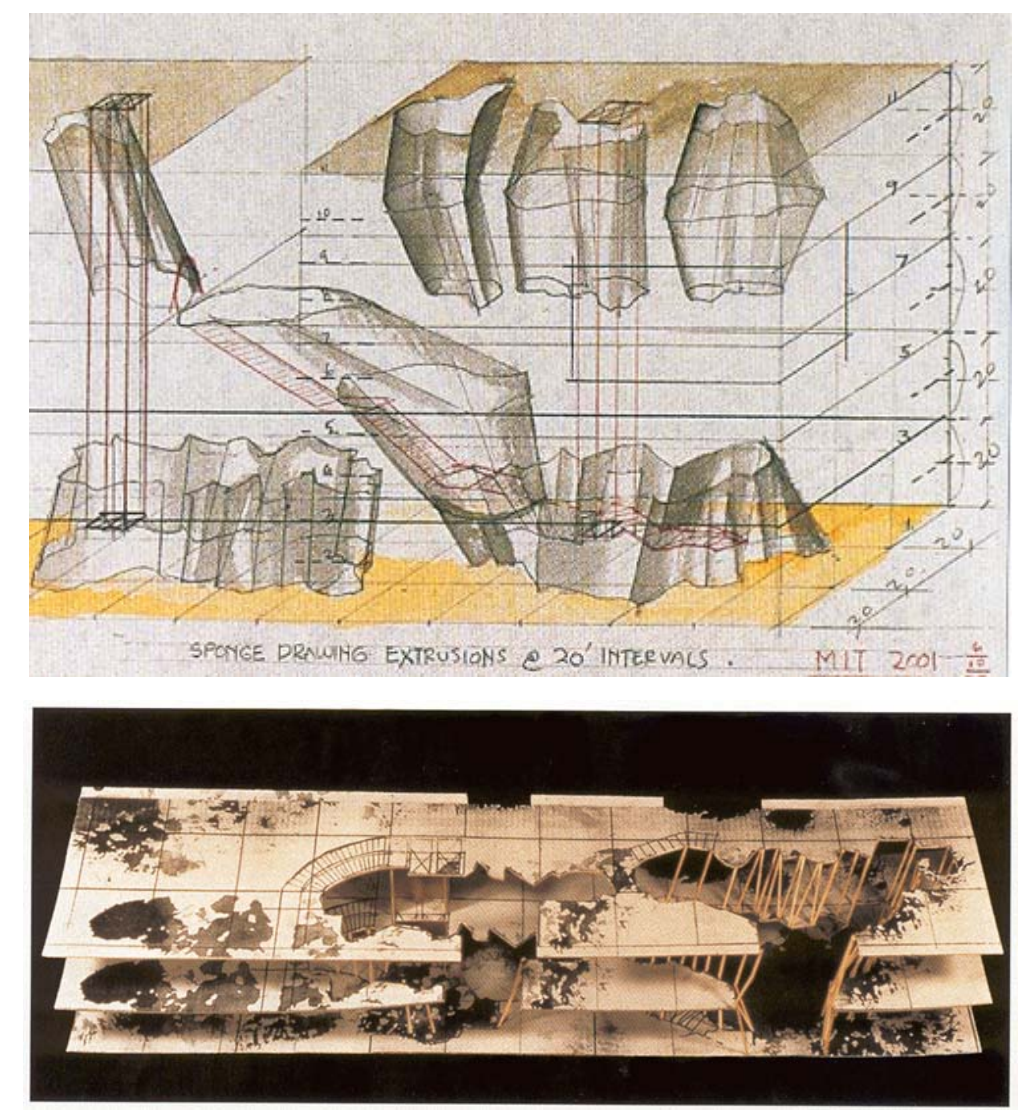

Figures 4.18 and 4.19. Sponge painted plans generating horizontal porosity: Simmons Hall, Massachusetts, 1999-2002.

${ }^{222}$ Op. cit. Holl, S., 2003, El croquis, p. 508. 


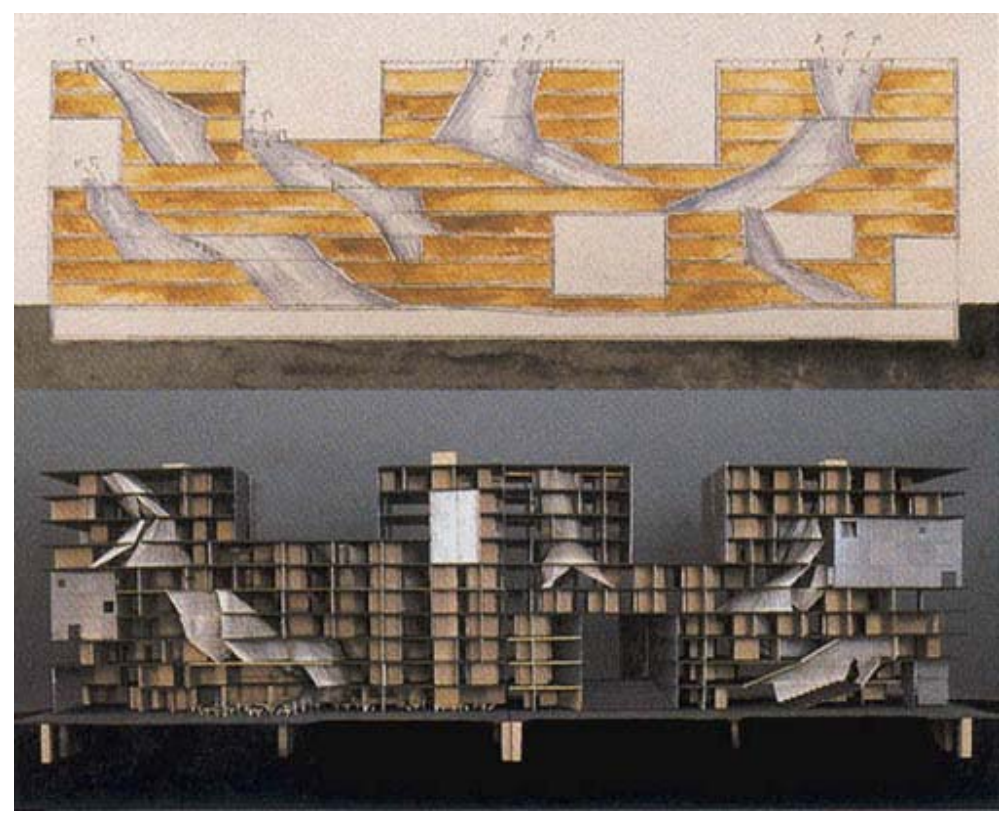

Figure 4.20. Organic “Lungs” generating vertical porosity: Simmons Hall, Massachusetts, 1999-2002.

What Holl calls the "lungs" of the building, or in Yehuda E. Safran's words "unique light chimneys, "223 organic openings provide to convey natural light throughout all levels, while an experiential relation between them can be established. The façade of the building exhibits a porous structure through modular square windows. The regular arrangement of windows is broken with irregular and bigger openings, whose locations respond to common areas of the dormitory. While the horizontal porosity connects different floor levels, the façade, like a porous membrane, brings the promise of establishing a visual interaction between interior and exterior.

Holl calls the building "a vertical slice of a city," signifying the experiential depth specified through the concept of porosity. ${ }^{224} \mathrm{He}$ works with the potential of his design to improve living in a dormitory. Alternative to the modular plan understanding of dormitory design, he emphasizes common spaces where students are allowed to come together, talk, discuss and communicate with each other. Thus, dormitory life, he says, is

\footnotetext{
${ }^{223}$ Yehuda E. Safran, April 2003, "Holl's hall of residence for MIT is..." in Domus vol. 858, p. 57.

${ }^{224}$ Op. cit. Holl, S., 2000, index.
} 
not confined within rooms, but rather runs over spaces of corridors, lounges and restaurants, offering experiential and social continuity. Yehuda E. Safran points out the social dimension of Holl's Simmons Hall project emphasizing that "the dormitory is no longer simply a place to sleep," instead is "a place that offers a fully fledged social program of activity.,"225

In this project, a physical context within the site is offered. The concept of porosity Holl achieves becomes a vehicle of developing a morphological strategy in design process. Yet the way sponge image is followed by the conceptual diagrams can be stated as a literal translation of image into design. The location of organic openings on plan level is stated to be created by pressing a sponge painted with ink onto paper, which exhibits more an experimental practice than a morphological examination.

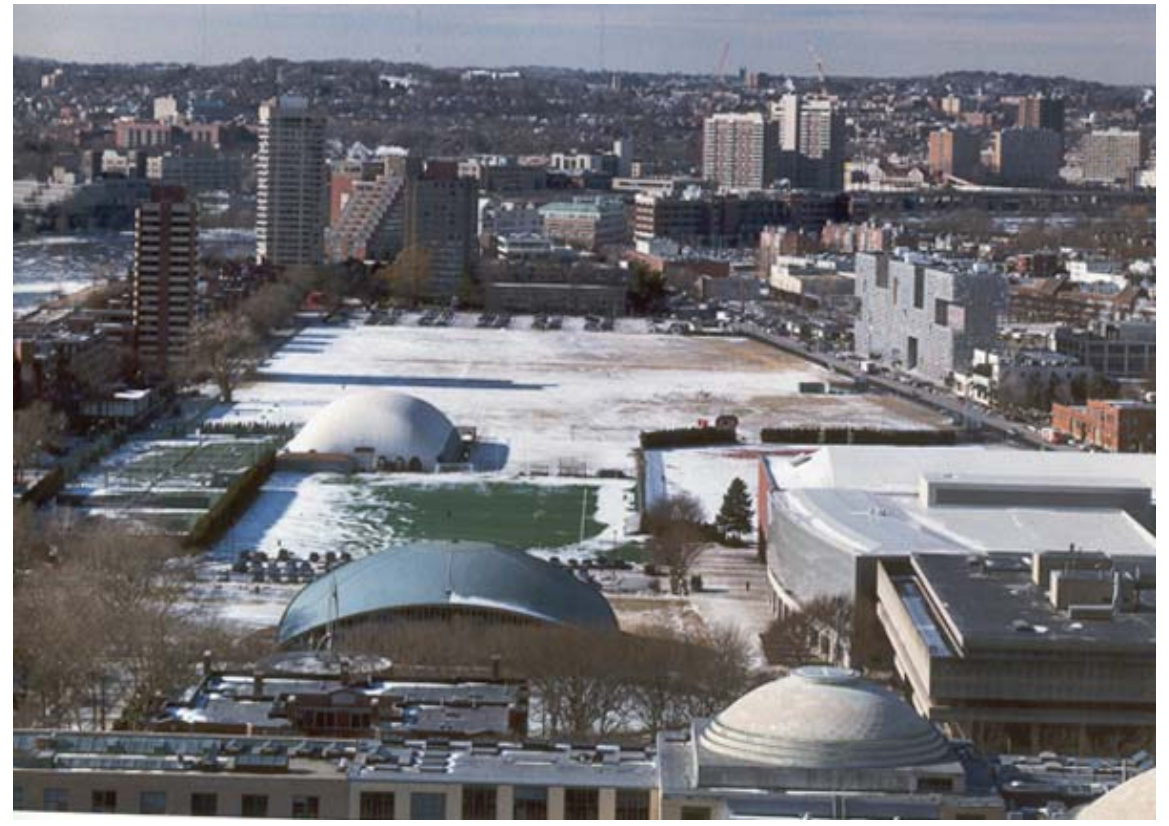

Figure 4.21. The location of Simmons Hall in the MIT Campus.

${ }^{225}$ Op. cit. Safran, Y., April 2003, p. 56. 
Steven Holl designed a museum in honor of $20^{\text {th }}$ century writer Knut Hamsun in Norway. Having read nearly all works of the writer, Holl was inspired from a part of Hamsun's novel "Hennig Carisen Hunger":

"When I was indifferent to myself at that time and when I was thinking that I was nothing other than a battle ground of invisible forces, I was aware of the happenings around me. A large brown dog ran across the street towards the trees and Tivoli along with it; its small collar was made of Mexican silver. Further in the street a girl with sleeves rolled up her arms emerged at the first floor of a house and she started wiping the windows. I didn't miss anything. I was determined and my mind was well and alive. Everything was happening in front of me. The lady in front of me had a hat with two blue feathers and she had a colored scarf around her neck."226

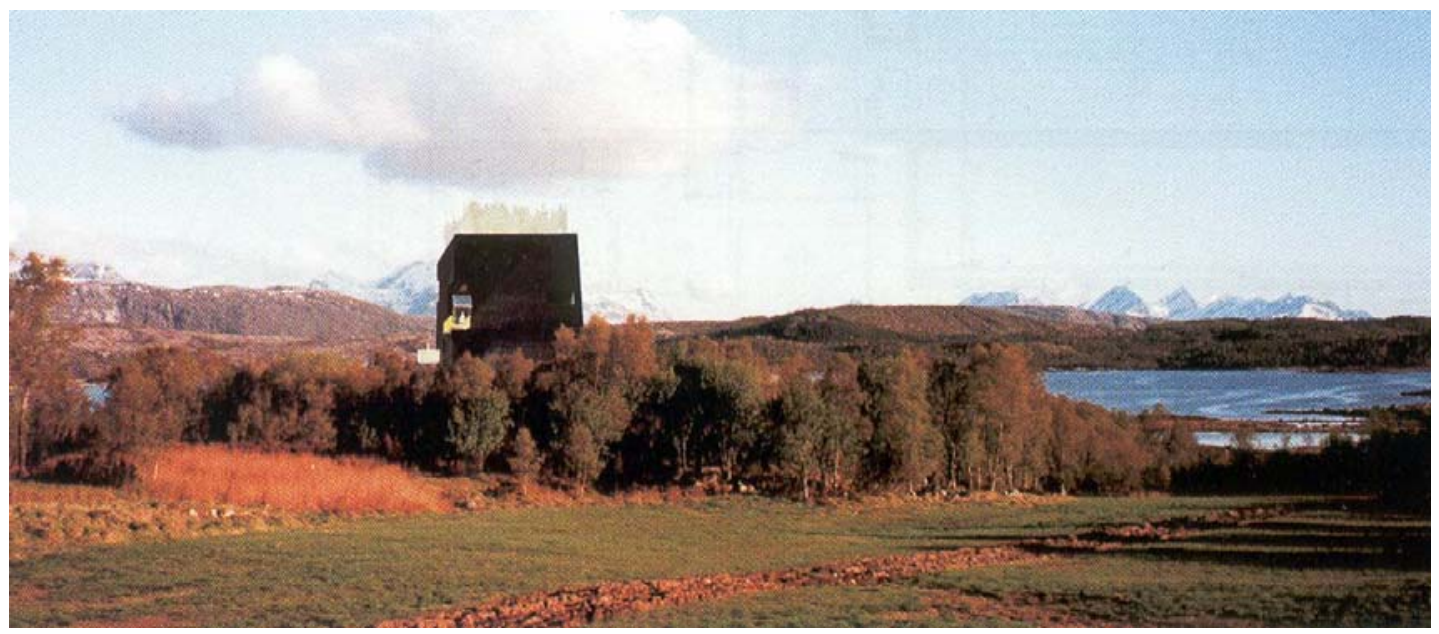

Figure 4.22. Knut Hamsun Museum, Norway, 1996/98-

Holl concentrates on the characters explained in the novel and especially on the main character that is the writer himself. In his novel, Hamsun expresses his psychological mood as "a body- battleground of invisible forces," 227 which leads the conceptual base of Holl's architectural design. Architectural form is interpreted as a body and attributed distinct human features. While a viewing balcony in yellow is meant to express "a girl with sleeves rolled up polishing yellow panes," the canopy of another balcony resembles the "woman with two blue coatdress in hats." 228

\footnotetext{
226 "Steven Holl: Fikir ve Yöntem" (Steven Holl: Idea and Method) in Tasarım vol. 142 issue 6, 2004, pp. 75-76. (Trans. by author)

${ }^{227}$ Ibid. p. 108.

${ }^{228}$ Op. cit. Holl, S., 2003, El croquis, p. 311.
} 


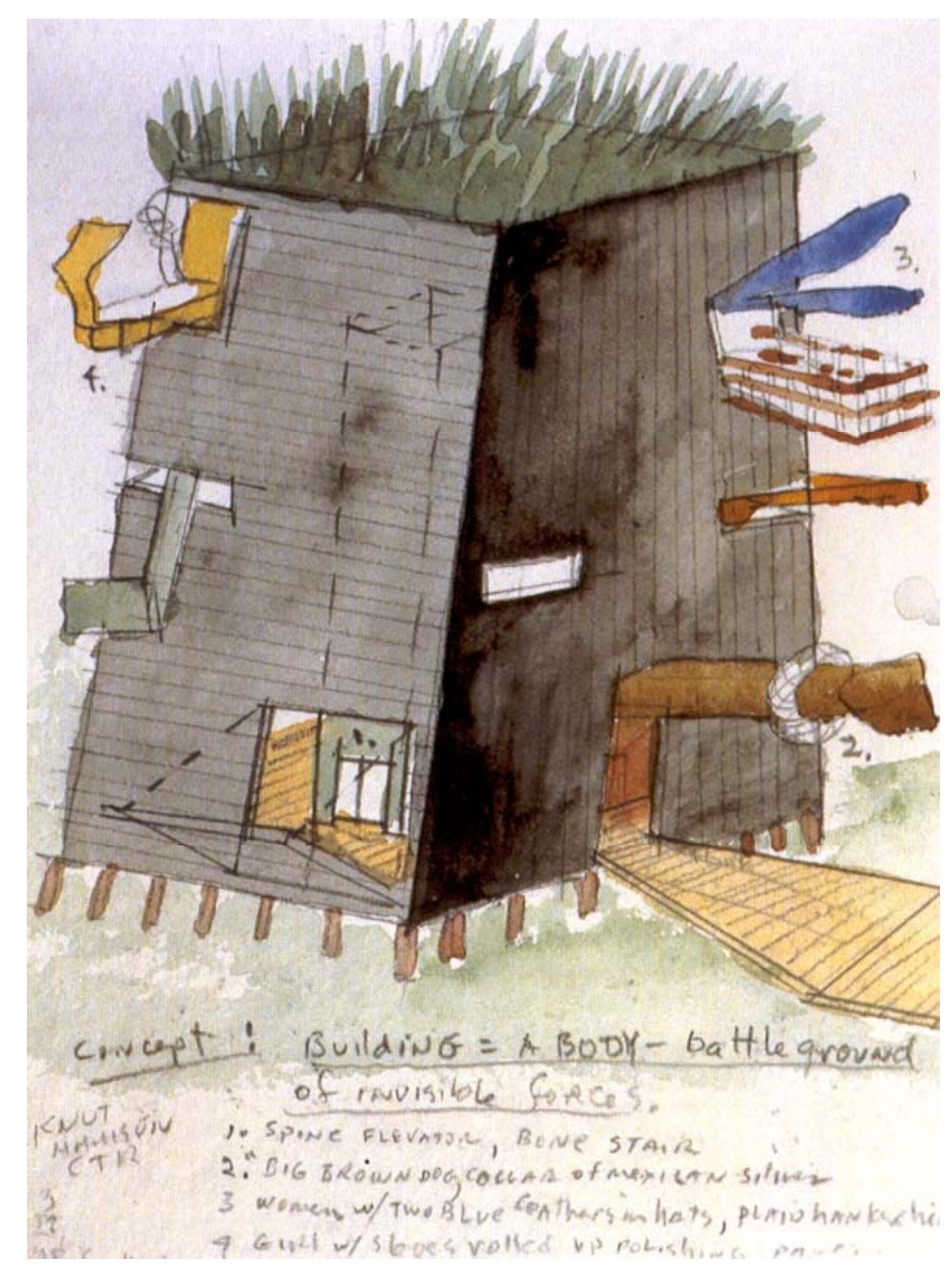

Figure 4.23. Concept sketch as "building: a body- battle ground of invisible forces": Knut Hamsun Museum, Norway, 1996/98-

The elevator located at center of the ground floor, says Holl, signifies "the spine of the building body" 229 The brown dog with collar of Mexican silver" characterizes the cantilever over the main entrance of the museum. Developed on the basis of characteristic features in Knut Hamsun's novel, the architectural work is personified. In Holl's design of Knut Hamsun Museum, it is noticeable that the architect searches for one-to-one geometric correspondence between literary characters and architectonic, which leads to a naïve simulation of a verbal reference in architectural design. The 
concept of "building as a body" is interpreted through a literal manner; irregularly located windows in different sizes and shapes on the black wood exterior are defined as "invisible forces" occurring on the" battle ground," which is the body, here the building. One could argue however that, in this way the architectural expression and the narrative behind the design concept become naive. Apart from the spatial configurations or material qualities, the bodily analogy is achieved literally.

As it is emphasized before, to inquire how successfully the final product expresses or concretizes the abstract, initial idea or concept is not the aim of this thesis. It is aimed, instead, to examine the way an idea or a concept constitutes the starting point of architectural design and the process wherein an idea-based approach leads to a built form. However, in his design of Knut Hamsun Museum, Holl does not give any clues about the process that the characters in Hamsun's novels condition architectural design. The architect puts forward a desire to express the literary characters in the realm of architecture. Yet, different from his other designs, the conceptual diagram that is the transformation of the concept into architecture is not presented, disregarding the formal, material or spatial relations. Therefore there is a discontinuity between the conceptual base and the architectonic form, which makes the relation between them naïve, or rather artificial.
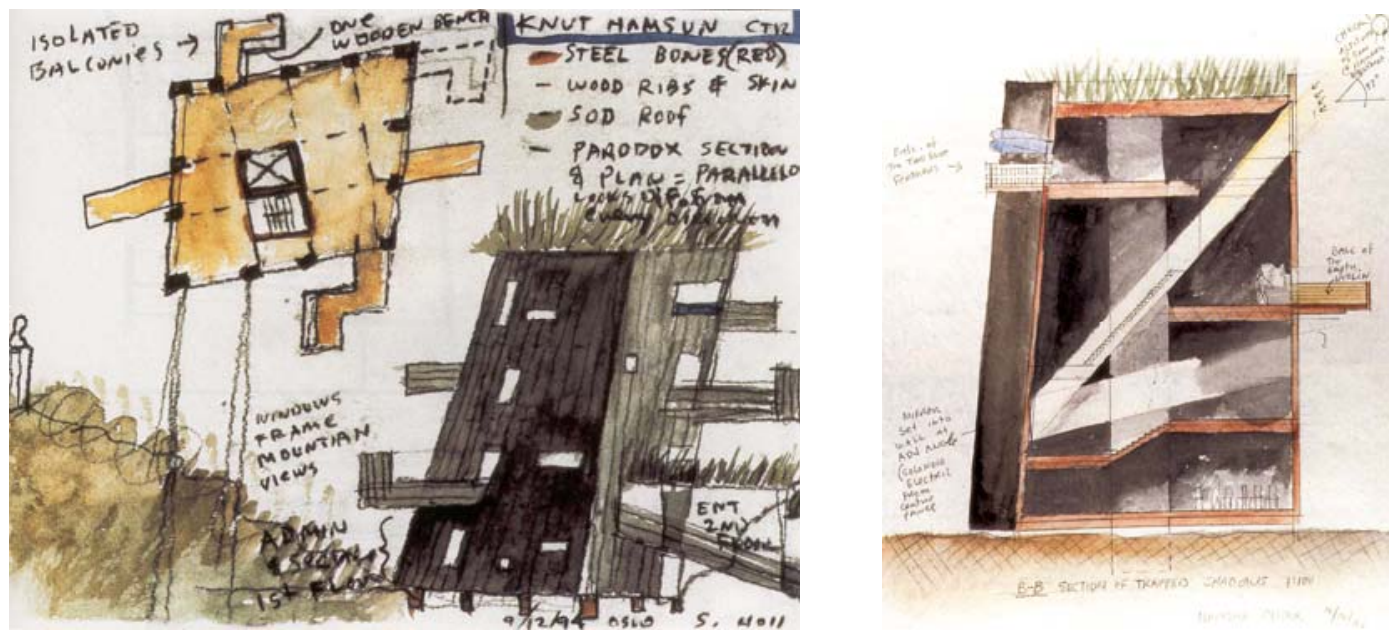

Figures 4. 24 and 4.25. Watercolor sketches of the Knut Hamsun Museum.

${ }^{229}$ Ibid. p. 308. 
In Holl's design, the concept serves as an agent, an imaginative construction that generates the architectural design process. However, the main purpose of the architect is not to achieve a one-to-one correspondence between the concept and form. Nor does he aim to impose a distinct concept to the perceivers through the experience of his buildings. Instead, he emphasizes that, architecture's fundamental potential is to present the possibility of infinite experiences for the perceivers. However, what is worth of an intensive investigation is, rather, the way his conceptual strategy guides his thinking and making of architecture.

In his article entitled "Steven Holl. Kavramsal Mimarliğın Yeni Ürünleri." (Steven Holl. New Products of Conceptual Architecture) Uğur Tanyeli, architectural critique and historian, comments on Holl's architecture, which he describes as a 'conceptual' approach. $^{230}$

According to Tanyeli, Holl's designs ground on various fictions, or stories, where he introduces various concepts as the departure point of the design process. Tanyeli critically emphasizes that, the relation Holl proposes between stated concept and architectural product is an 'arbitrary' one, which he explains as follows:

"One of the current approaches of architectural realm is a 'conceptual' attitude. The conceptuality, here, is caused by the fact that the perceptual product becomes an object of setting up and solving of a code, as it is in conceptual art. The code that is created and, then, expressed in the product should not necessarily be related to the internal arguments of architecture. That is to say, it is not expected to claim to solve particular functional, constructive, economic problems or to take environmental problems into consideration. The relationship between 'code' and 'product' is, rather, an arbitrary relation determined by the architect who is the creator of both." 231

Before speculating on Tanyeli's criticism, it will be appropriate to clarify the conceptual approach Holl puts forward in his projects.

\footnotetext{
${ }^{230}$ Op. cit. Tanyeli, U., February 2002, p. 40.

231،"Mimarlık dünyasının güncel izleklerinden biri de "kavramsal" olarak nitelenebilecek bir tavır. Buradaki kavramsallık, tıpkı kavramsal sanatta olduğu gibi, ortaya konan algılanabilir bütünün bir tür şifre-kurma ve şifre-çözme etkinliğine nesne olamsından kayanaklanıyor. Yaratılan ve üründe dışa vurulan şifrenin mimarlık dünyasının kendi iç tartışma konuları içinde bulunması gerekmiyor. Yani, belirli, işlevsel, konstrüktif, ekonomik ve çevresel değerleri dikkate alan bir problem çözme iddiası yansıtmasi
} 
The conceptual approach of the architect is, indeed, strategic. In every design, the architect firstly examines the site, situation, or program and then, forms a particular concept through which architectural design develops. Therefore, his conceptual strategy provides the architect with proposing unique departure points for each design. This is his strategy of practicing architecture. In doing so, he avoids an architectural vocabulary of style.

The emergence of a concept does not occur within contextualist or stylistic manner. It derives from architect's subjective re-interpretation of a particular situation. Thus, the subjectivity of conceptual strategy makes it, in a sense, "arbitrary", as Tanyeli calls it. The formation of a concept exhibits a subjective selection that is generated through the examination and re-interpretation of a situation unique in each project. However, Holl's approach is not an attempt of creating a puzzle that the viewers are expected to solve. Rather than aiming to impose a stated concept, the architect searches for the potential of evoking infinite experiences of built form.

Steven Holl does not regard architectural practice as a problem solving issue; thus, to solve particular functional, constructive, economic, or environmental problems may not be the primary mission of his architecture. However, he aims to combine such parameters with subjective intentions. He deals with program, site, and situation, which for him produce a field of examination for establishing a unique relation between architectural work and its context.

The primary attribute underlying Steven Holl's architecture is the phenomenological framework of his thinking and making of architecture. For him, the architectural work should be experientially intensive. He states that this is possible provided that the 'phenomenal' and 'experiential' potential of ideas and concepts are investigated. $\mathrm{He}$ emphasizes: "I hope to connect phenomenal qualities with the conceptual strategy." ${ }^{232}$

beklenmiyor. Şifre ile ürünün ilişkisi, onların her ikisini de vareden mimarın belirlediği keyfi bir ilişkiden ibaret." Ibid. (Trans. by author).

${ }^{232}$ Op. cit. Holl, S., in Zaera Polo, A., 2003, p. 22. 


\subsection{The Conceptual and Experiential Anchoring of the Building into the Site and the Situation}

Steven Holl states that concentrating on the dynamics of a site and a situation, which can be physical, historical, mythical, set the ground to start architectural design. This is the focus of his "anchoring" manifesto; the anchoring of a building into its site occurs through a two-fold condition where it is possible to denote conceptual anchoring and experiential anchoring.

The conceptual anchorage of the building occurs prior to the physical and experiential one. The architect defines a particular situation for each design examining the physical references of the site, its history and meaning, or the program. The concept derives from this re-interpretation, through which architectural work becomes conceptually anchored into a distinct situation.

Then, this conceptual anchorage is raised into an experiential level through the physicality of the built form. A new situation is set forth on the basis of the spatial articulation of the building and its experiential relation to the site. This created situation offers a particular spatial experience and it is this realm of experiences that the body, as a perceiver, becomes connected to building, site, and situation. Accordingly, the conceptual anchoring is transformed into an experiential rootedness belonging to that specific building and situation.

Moreover, Holl insists on a poetic dimension of building/site relation in architecture. This is an experientially generated poetics, where the physical experiences of the perceiver combine with subjective imagination. Within the imaginative dimension of anchoring, for Holl, poetry becomes the best medium exhibiting this intensive experience of place.

Steven Holl explains the concept generating his design of Museum of Human Evolution, in Burgos, Spain, as follows: 
"An Urban Mirror is created by situating the building over a platform of water recycled from the Arlazan River. The building makes a parallel to origin myths in the emerging of life in the ground through water. The river branches to the east connecting the site to the Atapuerca caves. Five points of fusion and overlap occur where the organic form (which begins with the Atapuerca caves) merges with the orthogonal forms (which begins in the urban Burgos)... The void-solid reversal of the central museum geometry, which extends from the organic cave outlines, corresponds to a non-dualism of nature\&man. This argument for a non-dualistic consciousness is further indicated in the Arlazan River water connection at the urban mirror platform. The Museum of Human Evolution hovers over a 'Chromatic Space' between the urban mirror and the undersides of the museum and auditoriums. This space of floating and reflection corresponds to the long span of time before humans first became conscious of their own evolution. "233

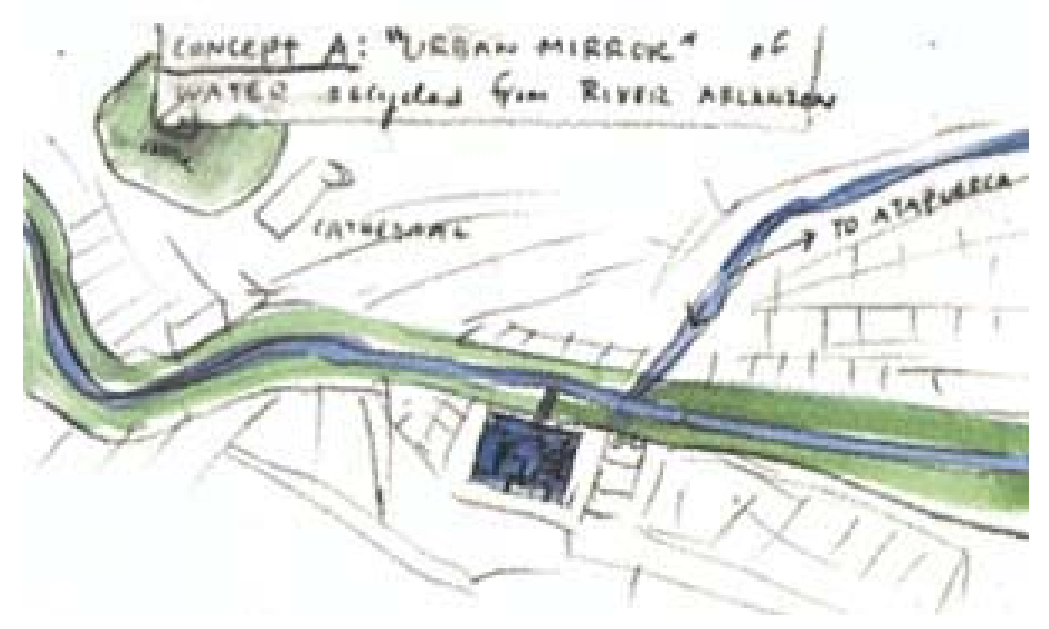

Figure 4.26. Site plan: Museum of Human Evolution, Burgos, Spain, 2000-

${ }^{233}$ Op. cit. Holl, S., 2003, El croquis, p. 418. 


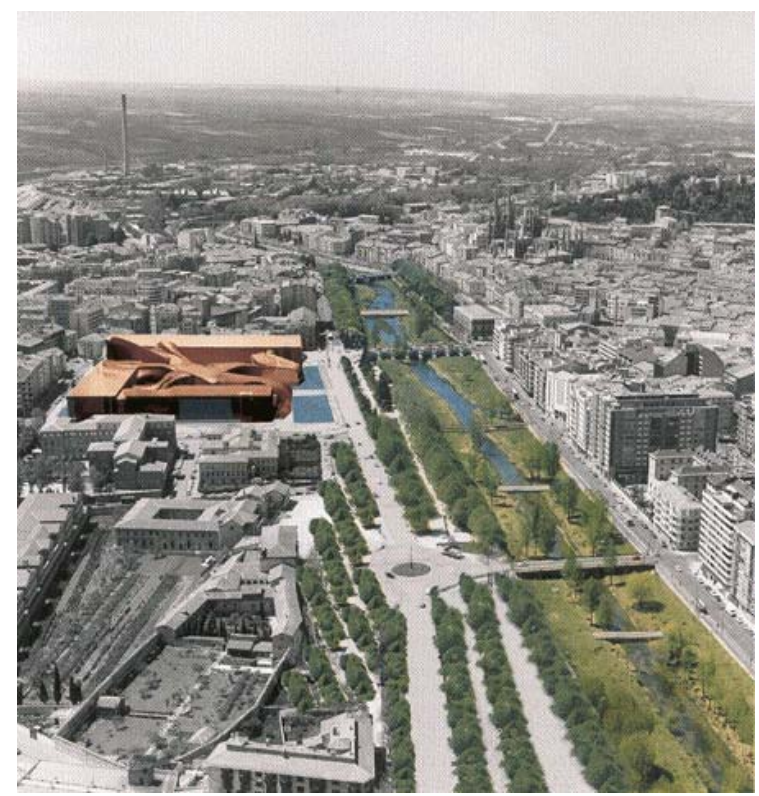

Figure 4.27. Photomontage of model in the site:Museum of Human Evolution, Burgos, Spain, 2000-

In Human Evolution Museum project, it is possible to mention the conceptual and experiential anchoring of architecture into a situation. Here, it is the history of the site that Holl begins with. He focuses on the remains of a pre-historical cave, called "Atapuerca". The cave is interpreted as expressing the ancient periods of human beings' life. Holl focuses on the cave as being a starting point in human evolution. Evolution can be stated a process involving change and development. In his design of the museum he puts forward an architectural study of human evolution, dealing with the cave as a mythical and poetic metaphor. The "Atapuerca Cave" generates the conception of museum design and, then, the articulation of the building. Thus, the museum building conceptually anchors into its site. 


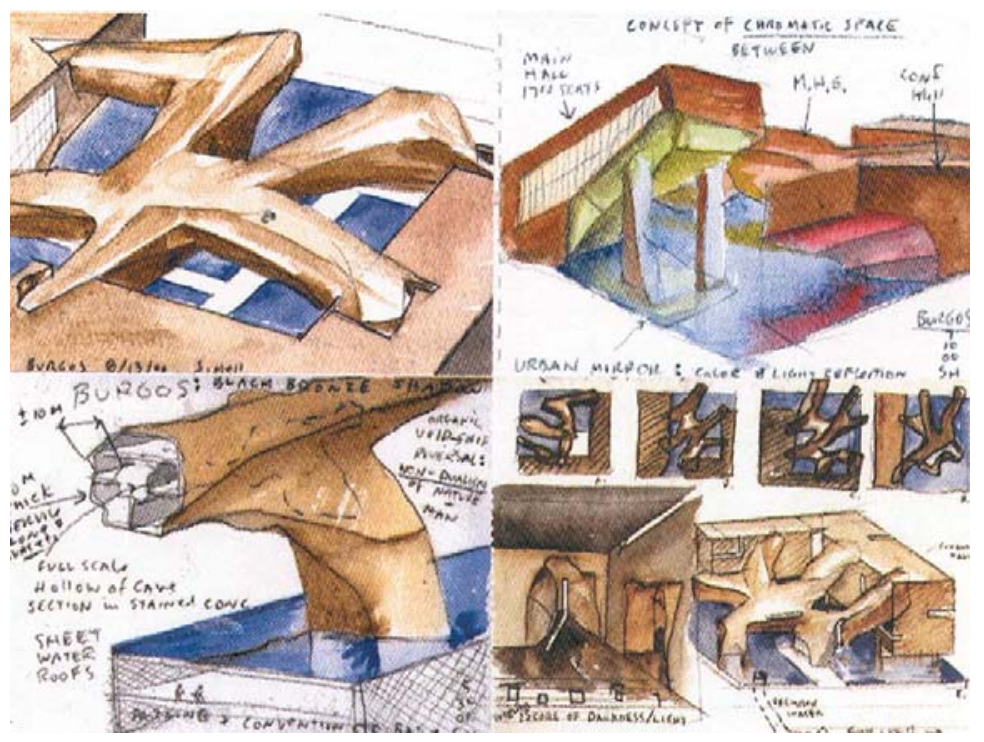

Figure 4.28. Studying with overlapping contrast: Museum of Human Evolution, Burgos, Spain, 2000-

For Holl, the anchoring of architecture into a site and situation is a condition in which "the meaning of situation" is "gathered" through the physical presence of built form. ${ }^{234}$ The meaning he deals with may be a historically, culturally, or experientially generated meaning. In this design, the stated meaning derives from the evolution of human life, which involves the overlapping of contrasts. According to Holl, there exist a conflict between pre-historical periods and the present, leading to a tension between the raw, organic geometry of the cave and the concrete form of present urban fabric. The architectural form of the museum building exhibits this overlapping situation. Developing around the replica of the "Atapuerca Cave" the central organic geometry becomes inserted into concrete, rectangular forms surrounding it.

In this project we come across a mythically generated meaning. The museum building "gathers", to use Holl's term, the mythical and poetic meaning through its physical presence. Studying with a situation-dependent meaning, the architectural design process opens up to the creation of a new situation. The architect not only interprets the existing

${ }^{234}$ Op. cit. Holl, S., 1989, p. 9. 
situation, but also creates a situation. As Holl states, the architectural work is integrated or "meshed" into the site and situation, wherein "a new place is formed."235
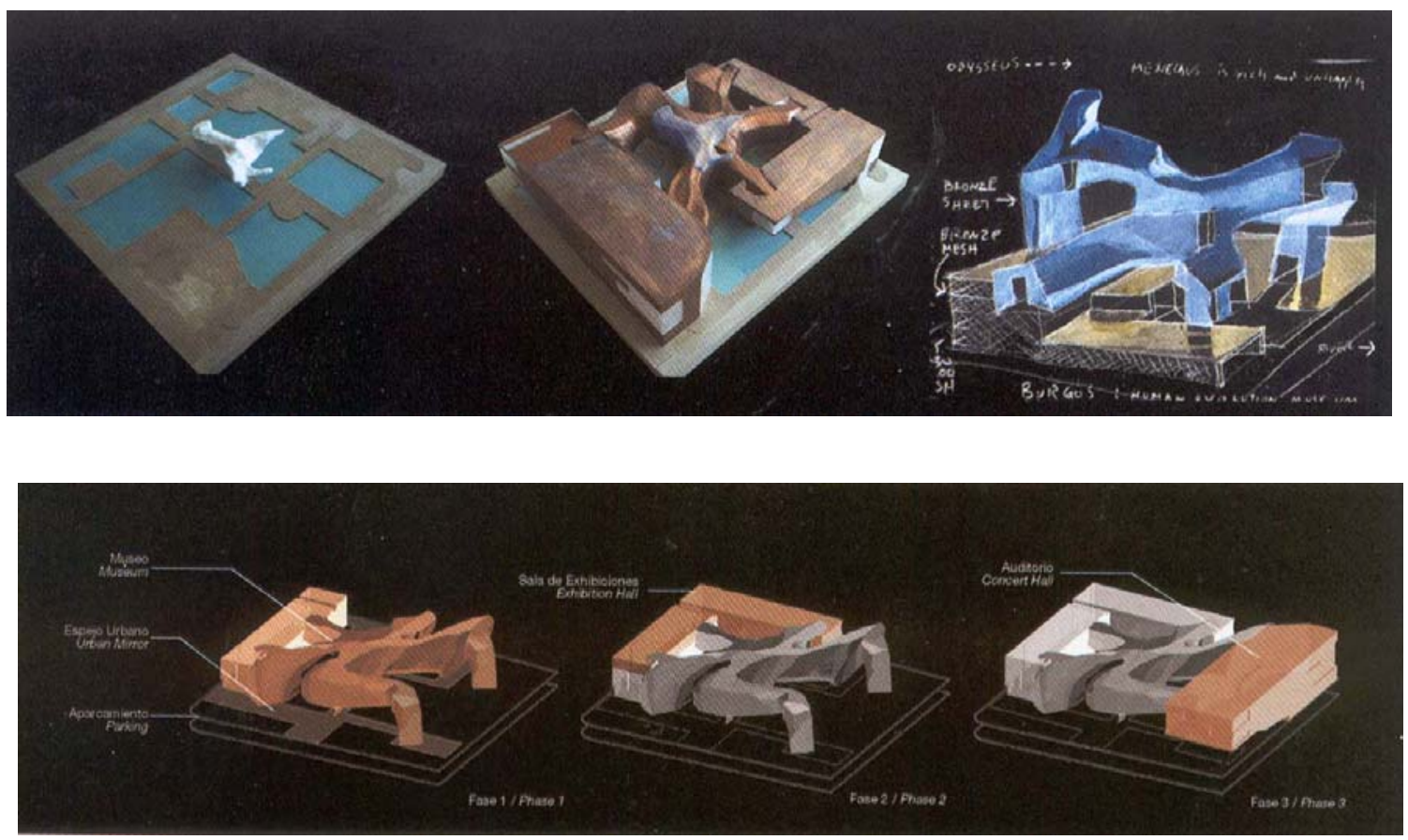

Figures 4.29 and 4.30. "Cave” metaphor as a design vehicle: Museum of Human Evolution, Burgos, Spain, 2000-

On the ground, and under the console of the organic geometry, there is a water platform, called as "Urban Mirror." The architect defines the space created between "Urban Mirror" and the organic console form a "chromatic space," where "a new silent urban place" emerges. ${ }^{236}$ A new situation is defined by the geometry of the building and its relation to the situation. This new situation is proposed to offer sense of place and unpredictable experiences, depending on reflections of the building onto the water platform. Therefore, the conceptual anchoring of architecture acquires an experiential dimension where the perceiver experientially becomes connected to the building and the situation.

\footnotetext{
${ }^{235}$ Op. cit. Holl, S., 1993, "Pre-theoretical ground," p. 26.

${ }^{236}$ Op. cit. Holl, S., 2003, El croquis, p. 418.
} 

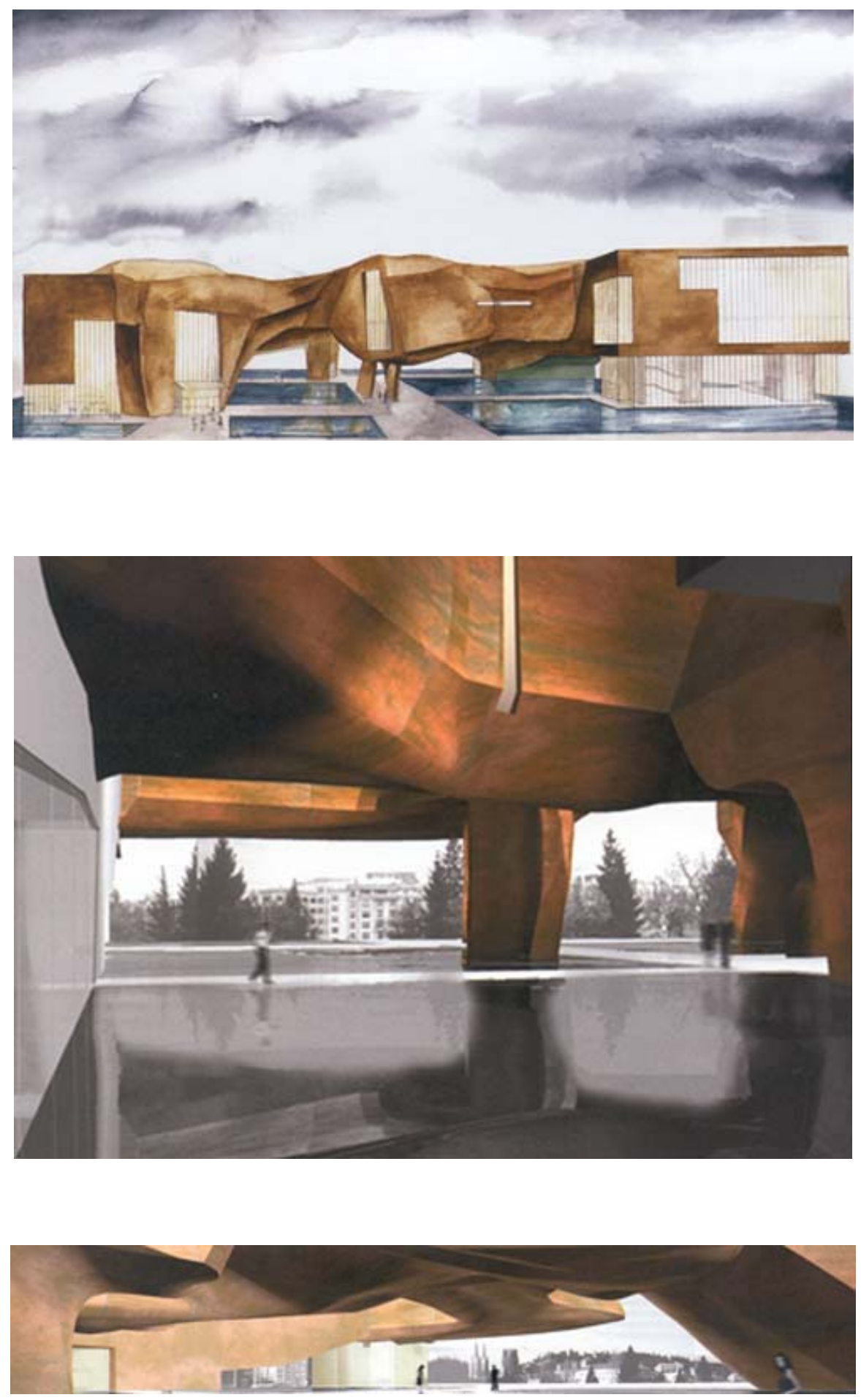

Figures 4.31, 4.32, and 4.33. 'Chromatic Space' acting as an Urban Mirror: Museum of Human Evolution, Burgos, Spain, 2000- 


\subsection{Body, Movement and the Architectural Space}

Emphasizing the concept of parallax, which can be defined as a sequence of surfaces generated as a body moves in space, Steven Holl introduces a significant situation that can be interpreted as a design tool for enhancing sense of space and material effects. According to Holl, studying parallax offers the potential to investigate the alteration in perception of spaces, light and shadow effects.

In the initial conception phase of design, he starts working with watercolor sketches, where he searches for spatializing an intellectual image. These watercolor sketches exhibit, indeed, the varying spatial perception of a moving body. Due to watercolors potential to grade the effects of light and shadow by toning, in Holl's sequential sketches the sense of movement is made manifest. In articulating spaces, the presence of body and motility become two important parameters, for the architect, "measuring architectural space," perceptually. ${ }^{237}$

In Helsinki Museum of Contemporary Art, the sense of movement and fluid spatiality are the major design issues the architect works with.

The exhibition of a work of art in a particular space and viewer's performance of experiencing this artwork constitute the basic themes of the museum, as a concept. Within this framework, in his design, Steven Holl primarily focuses on exhibition galleries presenting use with a search for how space contributes to the exhibition.

${ }^{237}$ Op. cit. Holl, S., 2000, p. 38. 

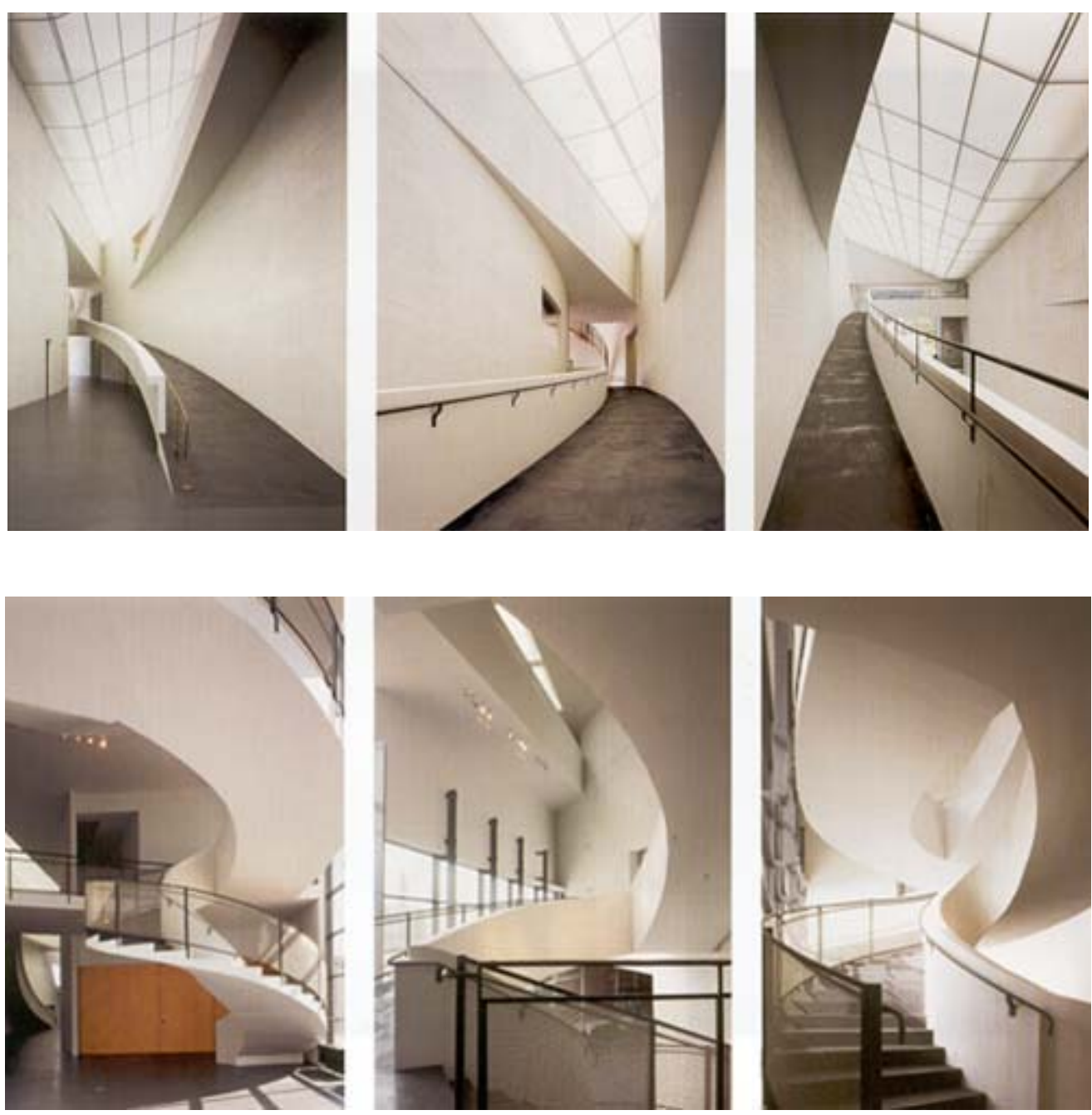

Figures 4.34 and 4.35. The fluid spatiality presented through circulation elements: Helsinki Museum of Contemporary Art, 1993-98.

The architect works with the spatial sense of the curved geometry of building, the ramp and the light effects in galleries, wherein the experiences of a body moving through spaces are investigated.

The curved form of museum building marks the spatial formation of exhibition galleries, which are not regularly rectangular, but in varying forms and sizes. For Holl the way body surveys architectural space resides in the varying spatial perceptions of body moving through space. Thus, architectural space is meant to offer a dynamic and unpredictable experiential realm for perceivers, which he explains as follows: 
"The design for the Helsinki Museum of Contemporary Art provides a variety of spatial experiences. We considered the contemporary artwork, and tried to anticipate the needs of a variety of artists including those whose works depend on a quiet atmosphere to bring out their full intensity...The general character of rooms, which are typically semirectangular, with one wall curved, allows for a silent yet dramatic backdrop for the exhibition of contemporary art. These rooms are meant to be silent but not static; they are differentiated through irregularity. Asymmetry defines movement through a series of spatial sequences, such that the overall design becomes a slightly warped "gallery of rooms." These curved unfolding sequences provide elements of both mystery and surprise... the visitor is confronted with a continuous unfolding of changing perspectives which connect the interior experiences to overall concept of Intertwining or Kiasma."238

Depending on the time of the day, natural light passing through roof windows into interior spaces causes alteration in light and shadow effects in galleries, thus, intensifying a sense of depth. Due to the continuous and fluid spatiality that is offered through the curved geometry of galleries and the white surfaces of walls, architectural space becomes a neutral ground both for exhibition and the viewer's experiences. In other words, the architect aims at inserting the artwork within the space, through which architectural space becomes an inseparable part of exhibiting and experiencing the artwork.

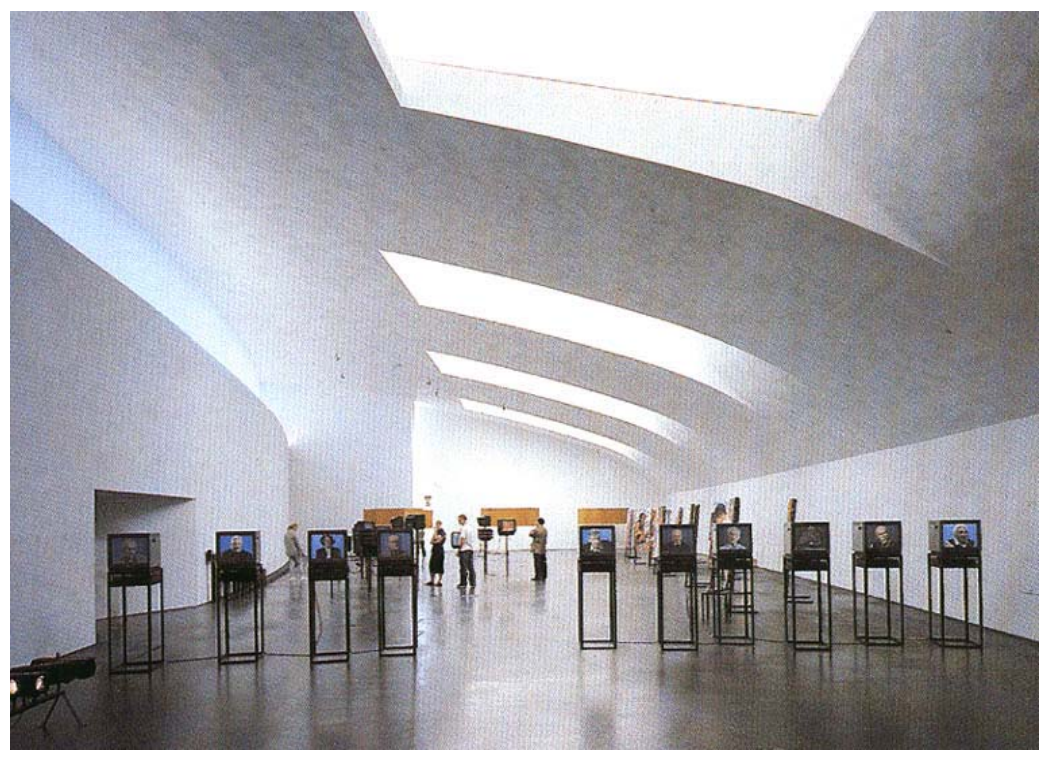

Figure 4.36. Space as a neutral ground for exhibition: Helsinki Museum of Contemporary Art, 1993-98.

${ }^{238}$ Op. cit. Holl, S., 2003, El croquis, p. 250. 

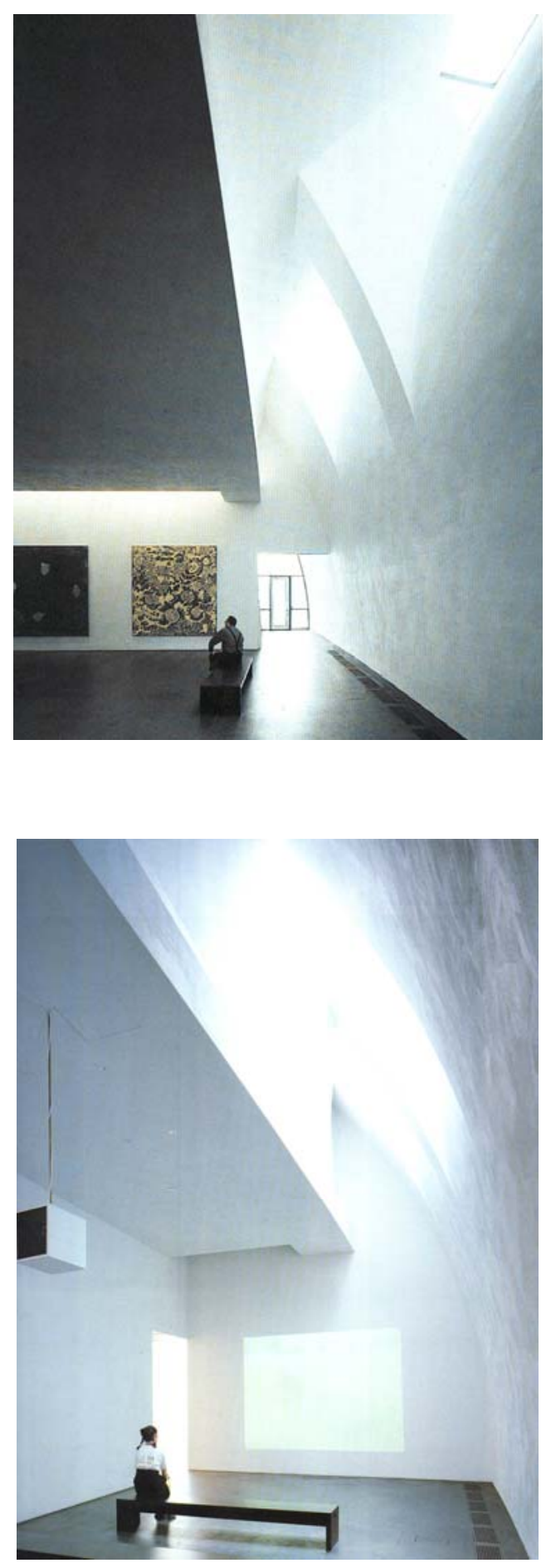

Figures 4.37 and 4.38. Exhibition galleries:

Helsinki Museum of Contemporary Art, 1993-98. 

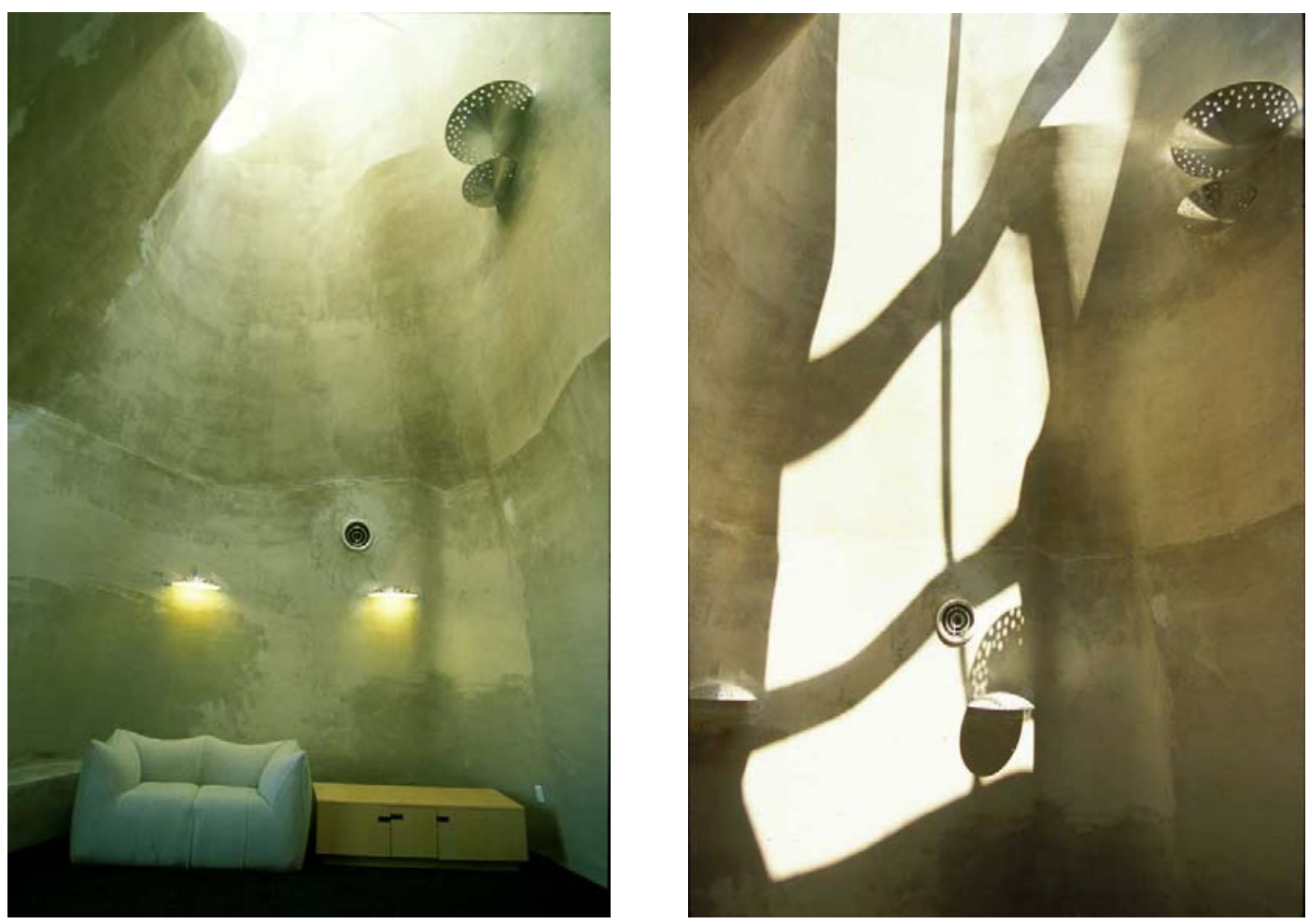

Figures 4.39, and 4.40. Effects of light create spatial fluidity: Simmons Hall, Massachusetts, 1999-2002.

In Simmons Hall, the sense of movement and spatial dynamism are the outstanding interior expressions of the building. The notions of permeability and continuity that are included in porosity concept, leads the architect to achieve a spatial expression through forms, material qualities and light effects in his work.

Light can be stated as one of the significant qualities leading to create the sense of movement in the building. As light is conveyed through shafts into organic and bare surfaces of lounge walls, sculptural light and shadow effects occur. The use of light, thus, intensifies phenomenal qualities of architectural spaces by offering changing spatial perceptions through which the dynamism of movement is made manifest. 

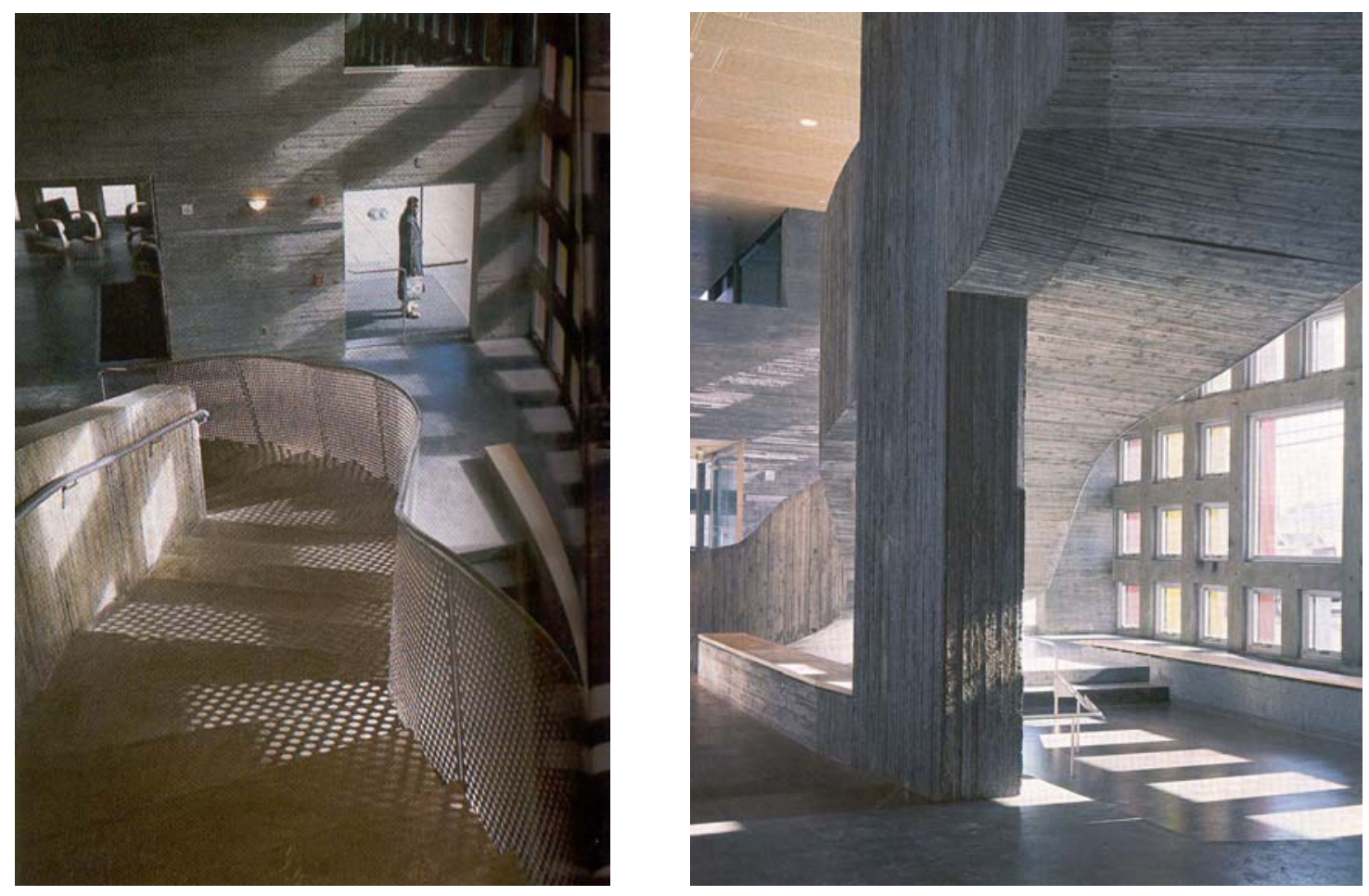

Figures 4.41 and 4.42. Spatial dynamism through organic forms:

Simmons Hall, Massachusetts, 1999-2002.

Besides geometric expressions and effects of light in spaces, the sense of movement is achieved by means of the organic and rough form of staircase. The bare concrete staircase with a curved geometry contributes to creating the effect of fluid spatiality.

In this example, it is noticeable that Holl works with the sense of movement, experimenting its spatial and material responses. He puts emphasis on a moving body's perceptions of architectural space, wherein light acts a space-defining element.

\subsection{The Phenomena of Architecture: A Haptic Field}

Steven Holl's architecture is distinguished with phenomenal characteristics of his work. While the architect starts with an idea, in articulating spaces and forms he investigates its 
phenomenal potential. It is due to this search of the architect that his making of architecture is rendered specific.

The reason underlining Holl's emphasis on the making of architecture resides in his ultimate aim of connecting the intellect with senses, idea with phenomena and body with environment. In order to do this, he puts forward the haptic sensibility in practicing architecture. For Holl, the experiential potential of architecture provides the discipline to establish such a connection; the connecting dimension of architecture is by reason of the phenomenal properties of a built form.

In view of his emphasis on the phenomenal experiences offered through architecture, Holl mainly focuses on the feeling of material texture, the details, and the spatial effects of light reflections, through which architecture's phenomenal potential is made manifest. What Holl calls the "haptic realm" is this multi-sensory experiential phenomenon, through which architecture speaks without words. The architect is concerned with the unpredictability of spatial and material experiences of a building and its tectonic impression. Therefore, as he states, "the play of light and shadow, the music echoes and textures and smells, the aura and presence of real materials" become the means through which architectural meaning is conveyed. ${ }^{239}$ Accordingly, Holl focuses on the experiential and emotional attributes of materiality and the spatial sense. How people receive the experiential depth of his architecture is his main concern. For him, the spatial, material, and light experiences of built form conduct the perceivers' understanding of architecture independently of architect's implications.

${ }^{239}$ Op. cit. Holl, S., in Kipnis, J., 2003, p. 38. 

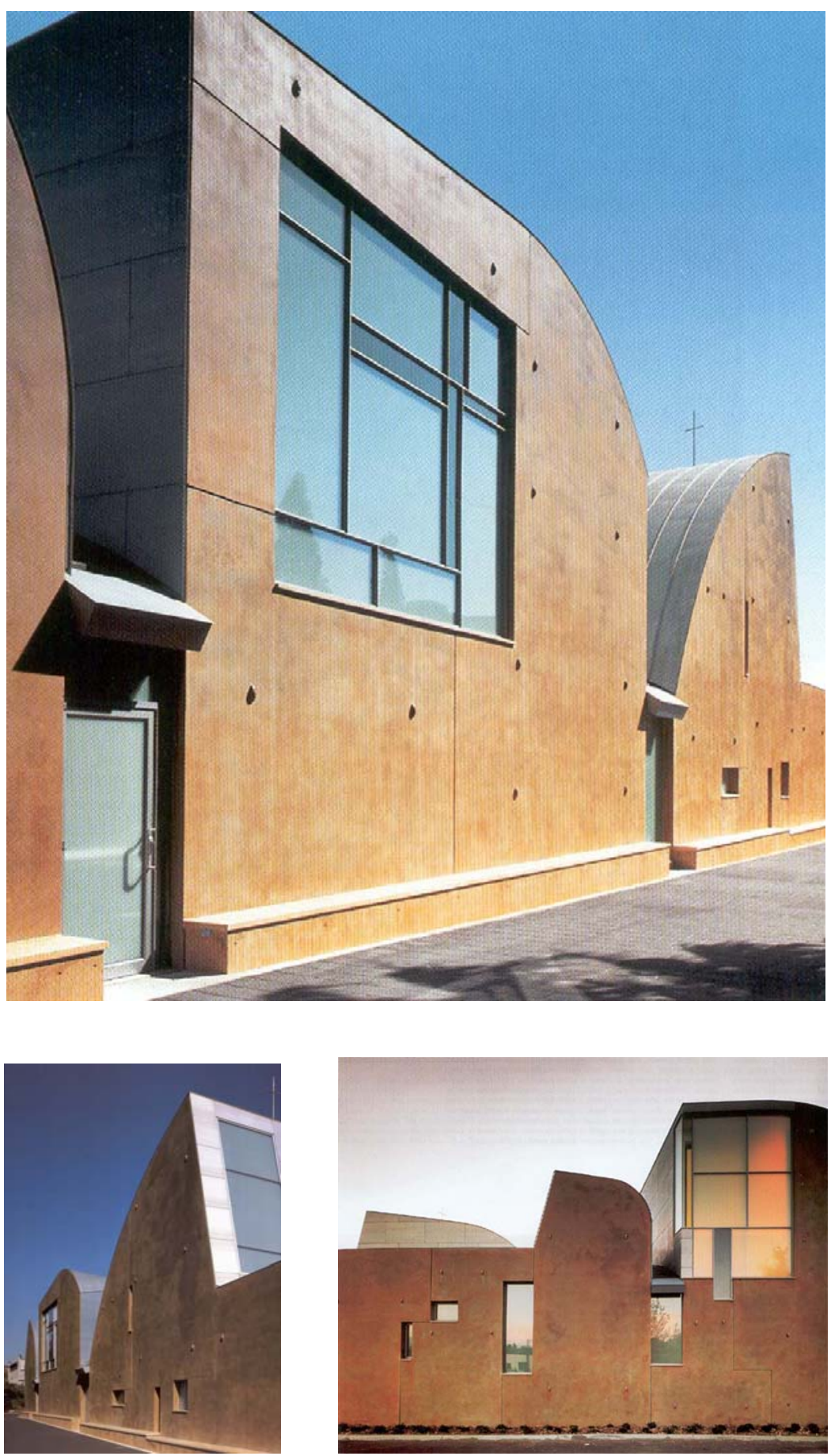

Figure 4.43, 4.44, and 4.45. The architectonic effect of the Chapel of St. Ignatus, Seattle, 1995-97.

In the Chapel of St Ignatus, it is possible to remark on the haptic sensibility of the architect in geometry, space and detail design. Besides the tectonic and geometric 
distinctness of the building, the materials he uses, the design of details, and the effects of natural and reflected light offer a phenomenal field, a spatial depth, in relationship with the spiritual function of the building. The building is constructed by interlocking 21 concrete panels with each other, where the locks can be distinguished on wall surfaces demonstrating the construction system of building, and, also, providing a unique tectonic effect.
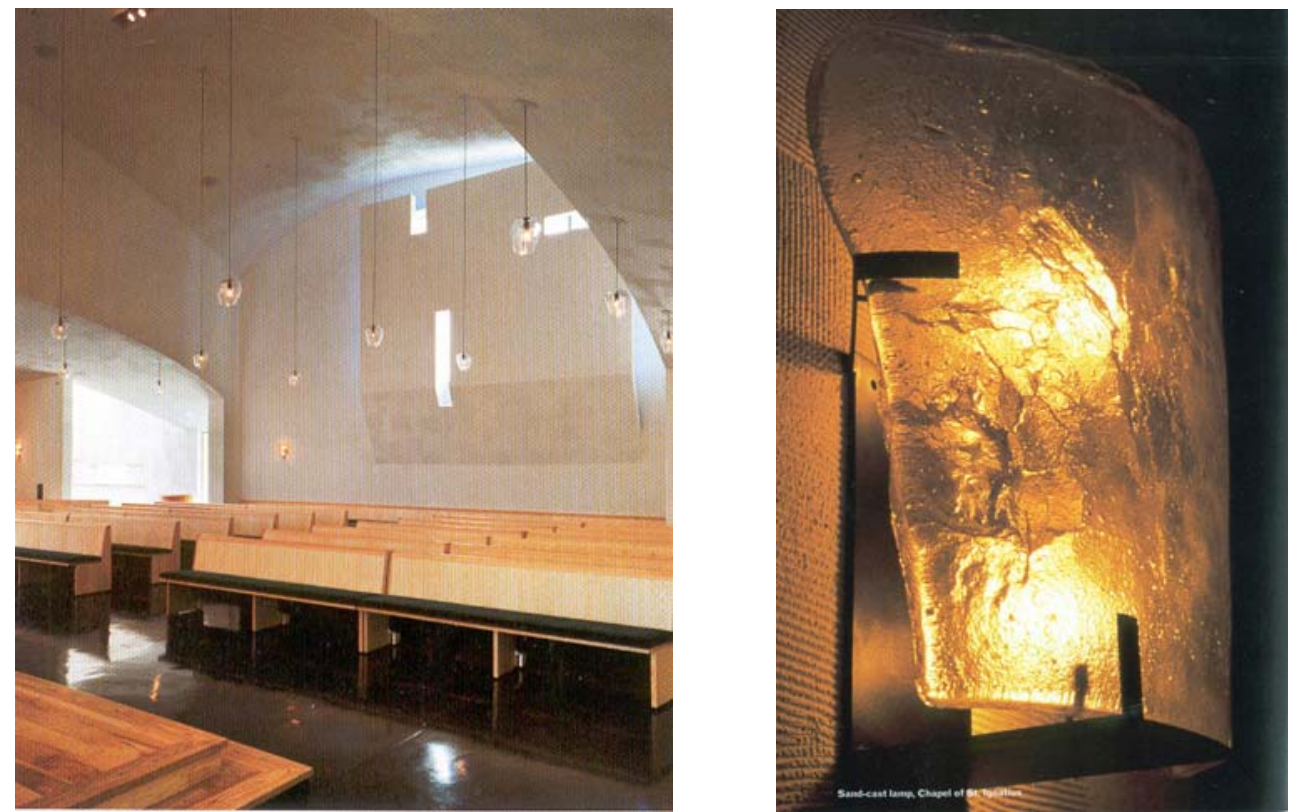

Figure 4.46. "Pews" inside the Chapel Figure 4.47. Sand-blasted lamp in the Chapel

As a feature enabling to distinguish his work from the rest of contemporary architectural practices, Steven Holl designs every detail of his buildings. In the chapel project, the furniture including the "pews", the "altar" used in religious ceremony, the chair of the priest, "baptistery", the lamps are among objects designed by the architect. It can be stated that Holl's works exhibit a craftsman's attention; he appreciates the material qualities and techniques in producing details. This provides Holl with the intensification of the phenomenal capacity of architecture. 
In his article "The Work of Steven Holl: 1980-1996 A Retrospective Prospect" Kenneth Frampton states that Holl interprets materials as having "a lyric capacity." 240 The "lyric" qualities of materials, as Frampton calls it, are related with the "chemistry" or "mood" of matter, which for Holl, is related with the emotive dimension of materiality. He states that beyond their physical and functional attributes, materials create sensory and emotive effects on the perceivers. In order to create experientially intensive architecture, he aims at revealing this emotional depth of matter. Besides its structural particularity, the Chapel of St. Ignatus can be distinguished by means of its material qualities; the "beeswax" covered walls create a texture that provokes a particular sense of touch. The "oil-rubbed, carved Alaskan cedar" door, on the other hand, has seven circular voids, leading to a literal association of the spiritual concept, which is meant to correspond to seven distinct Jesuit exercises. The pedant lamps and wall lights are made of "sand-blasted" glass.

Holl focuses on transforming material properties in architecture; by using various techniques, he experiments the spatial effects of material transformation. This provides him with better learning what kind of a spatial effect can be created through the use of a distinct kind of material. Insisting on "architecture's ability to shape our daily experiences in material and detail, ${ }^{, 241}$ Steven Holl characterizes his architecture by grounding his work on a haptic sensibility.
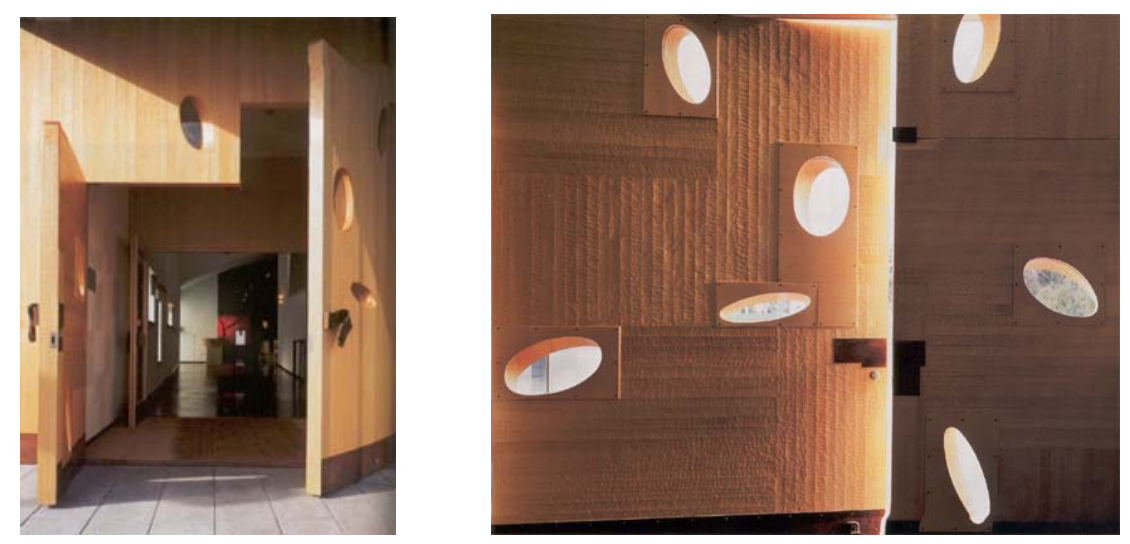

Figures 4.48. and 4.49The oil-rubbed, carved Alaskan cedar door: The Chapel of St. Ignatus, Seattle, Washington, 1994-97.

\footnotetext{
${ }^{240}$ Op. cit. Frampton, K., 2003, p. 539.

${ }^{241}$ Op. cit. Holl, S., 2000, p. 71.
} 


\subsection{1. 'Light' as a Structural Material}

Based on the haptic sensibility in form and space making, Steven Holl concentrates on light as an architectural element, or a structuring material. He experiments with the everchanging qualities of natural light and their spatial effects. It can be stated that Holl uses light poetically. In his buildings, natural light is transmitted into interior spaces, usually not directly, but through uniquely designed architectural elements, in order to control and structure light reflections. His use of light creates plastic and artistic effects. In Holl's experimentation of its phenomenal qualities, light becomes a space-defining factor through which a sense of spatial depth is brought into presence.
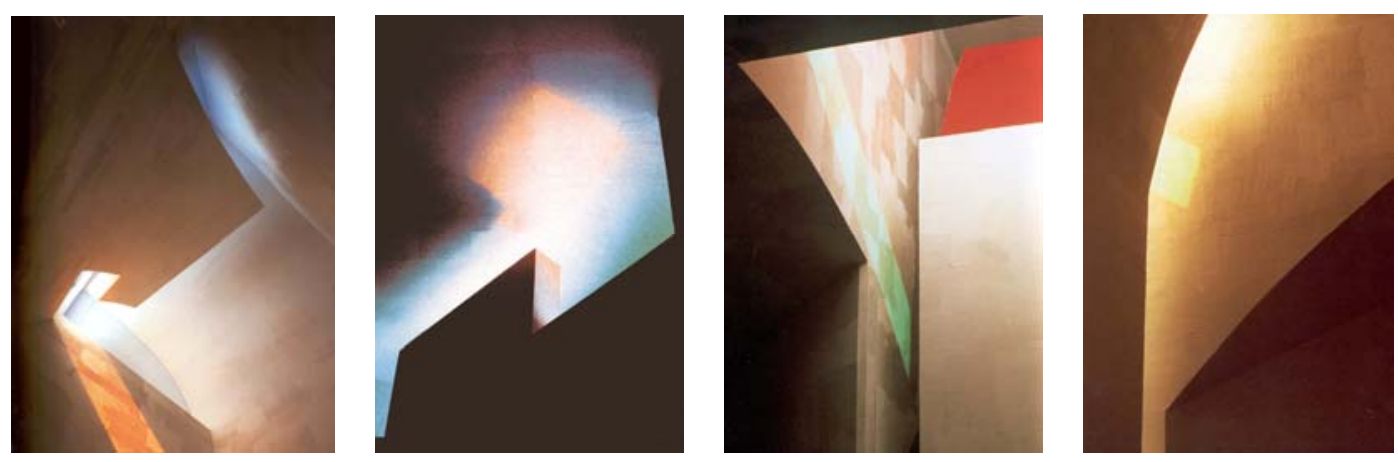

Figures 4.50, 4.51, 4.52, and 4.53. Light as a space-defining element in the Chapel of St. Ignatus.

In the Chapel of St. Ignatus, the conceptual and experiential core of Holl's design is established through the use of light. Besides its metaphoric use, Holl mainly concentrates on the spatial and geometric effects of light in architectural spaces. While the lenses of different colors cause a phenomenal division of interior volume into distinct parts, the architect searches for articulating spiritual exercises of Jesuit rite. "The light is sculpted by a number of volumes emerging from the roof," states Holl and mentions: "The concept of Different Lights is further developed in the dialectic combination of pure colored lenses and a field of reflected color within each light volume."242 The blue, purple, red, and orange lenses create varying color reflection within interior space of the 
chapel, elevating the metaphoric use of light into an experiential level through the built form.
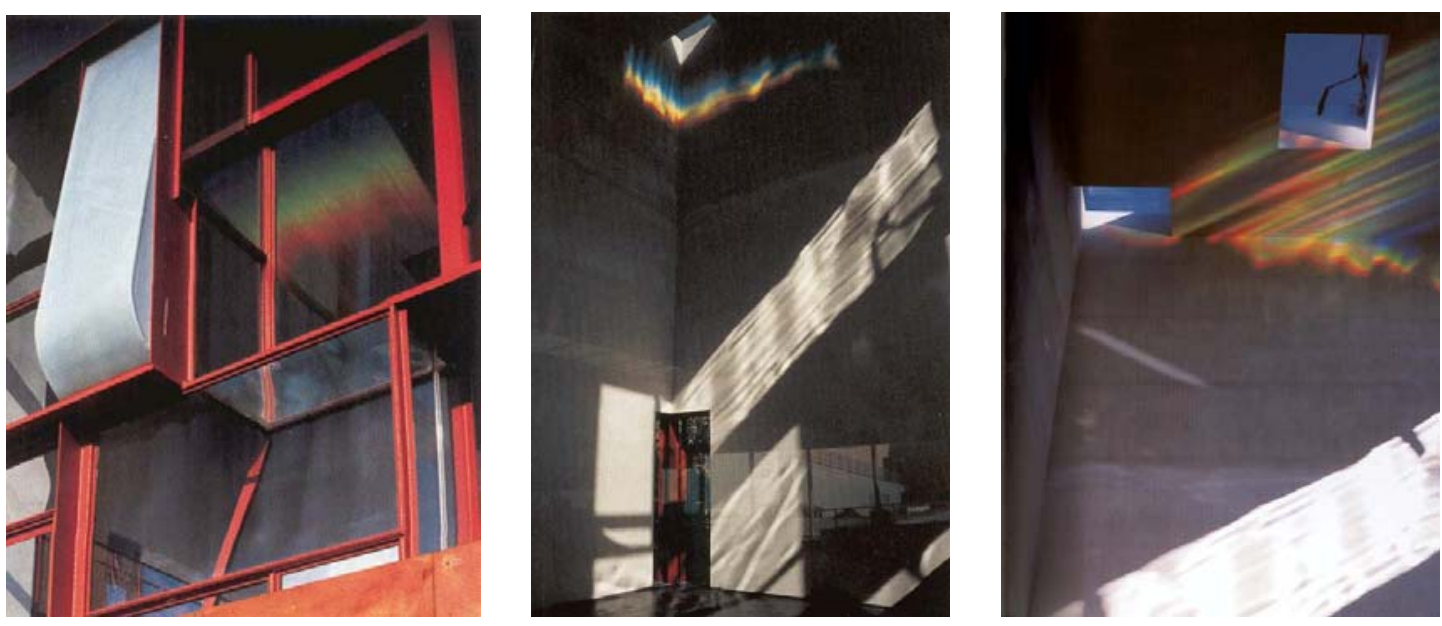

Figures 4.54, 4.55, and 4.56. "Light Laboratory" in the Addition to the Cranbrook Institute of Science, Michigan, 1992-98.

While the Chapel of St. Ignatus project involves a study on light reflections with various colors, in the Addition of Cranbrook Institute of Science, Holl experiments with the potential of light in measuring time. The architect defines the entry lobby as a "Light Laboratory" due to the way light is transmitted through the transparent façade with sections of differently structured glass. ${ }^{243}$ The use of "bending" glass, "cast" glass or "sand-blasted" glass provides the architect with experiment on the change of light reflections and refractions during daytime. In this laboratory, the filtration of sunlight through glass surfaces generates fluid spatial perceptions, varying due to the time of the day. Holl mentions:

"In the Light Laboratory at the Cranbrook Institute of Science, every day is different. Low winter sun refracts in luminous waves while a prismatic rainbow washes the blank wall in unpredictable iridescence. Diffraction in gentle waves suddenly merges with pulsing shadows that appear as inverted dancers near the ceiling. The speed of shadow is vibrant. The Light Laboratory, which is functionally the new entrance vestibule of the

${ }^{242}$ Op. cit. Holl, S., 2003, El croquis, p. 278.

${ }^{243}$ Op. cit. Holl, S., 2000, p. 112. 
renovated institute, is an experimental construction employing new glass lens techniques patterning light in motion for a living time in architecture."244

It is noticeable that he interprets light as an index of time in the perception of the built form. Architectural space and form is redefined by means of the changing light effects, through which the passing of time is implied; it is time in architecture. Opposed to the static condition of physical presence of a building, light enables to perceive and better understand that architecture exists in space and time.

Another fundamental property of light can be mentioned as its potential to conduct the way the texture of surface can be perceived. Depending on the way it is used, light effects cause to strengthen or diminish material texture. The shadows and shades create varying material and spatial senses in the perception of a building. Thus, due to varying textural effects, the use of light becomes an act intensifying the depth of architectural forms and spaces.

Holl points out the emotional and psychological dimensions in the experience of architecture. While perceiving a building the body enters into an intimate experiential realm, which is related to the psychological insights of the subject. Light has an influential role in the perception of architecture. In his book Anchoring Holl states as follows:

"Space remains oblivion without light. Light's shadow and shade, its different sources, its opacity, transparency, translucency, and conditions of reflection and refraction intertwine to define or redefine space. Light subjects space to uncertainty, forming a kind of tentative bridge through fields of experience. What a pool of yellow light does to a simple bare volume or what a paraboloid of shadow does to a bone white wall presents us with a psychological and transcendent realm of the phenomena of architecture."245

As he emphasizes above, Steven Holl's focus on can be related with the psychic implications of light in architecture. The perception of varying qualities of light is influenced by the psychological and emotional states of the viewers.

\footnotetext{
${ }^{244}$ Ibid. p. 28

${ }^{245}$ Op. cit. Holl, S., 1989, p. 11.
} 
In the Chapel of St. Ignatus, the architect looks for the psychological implications of architectural space. Based on the program of the project, the notion of spirituality characterizes the architectural spaces. Holl interprets light as a religious theme associated with the notion of illumination. Sunlight, slipping through colored lenses into spaces, creates spatial perceptions that provoke emotional and spiritual attributes.

Color, which Holl defines as "the absent referent to an experience," is an important quality in the phenomena of architecture. ${ }^{246}$ In his buildings, he works with color reflections and projections, experimenting the spatial and surface effects of color. Color indicates the supposed character of architectural space. It intensifies the architectural expression. It is influential in the perception of surface and form. In Holl's projects, the use of color is a distinct field of study. In Sarphatistraat Offices, Amsterdam, the building is characterized in terms of the color reflected through the porous façade onto the De Single Canal, which has an impressive vision at night.

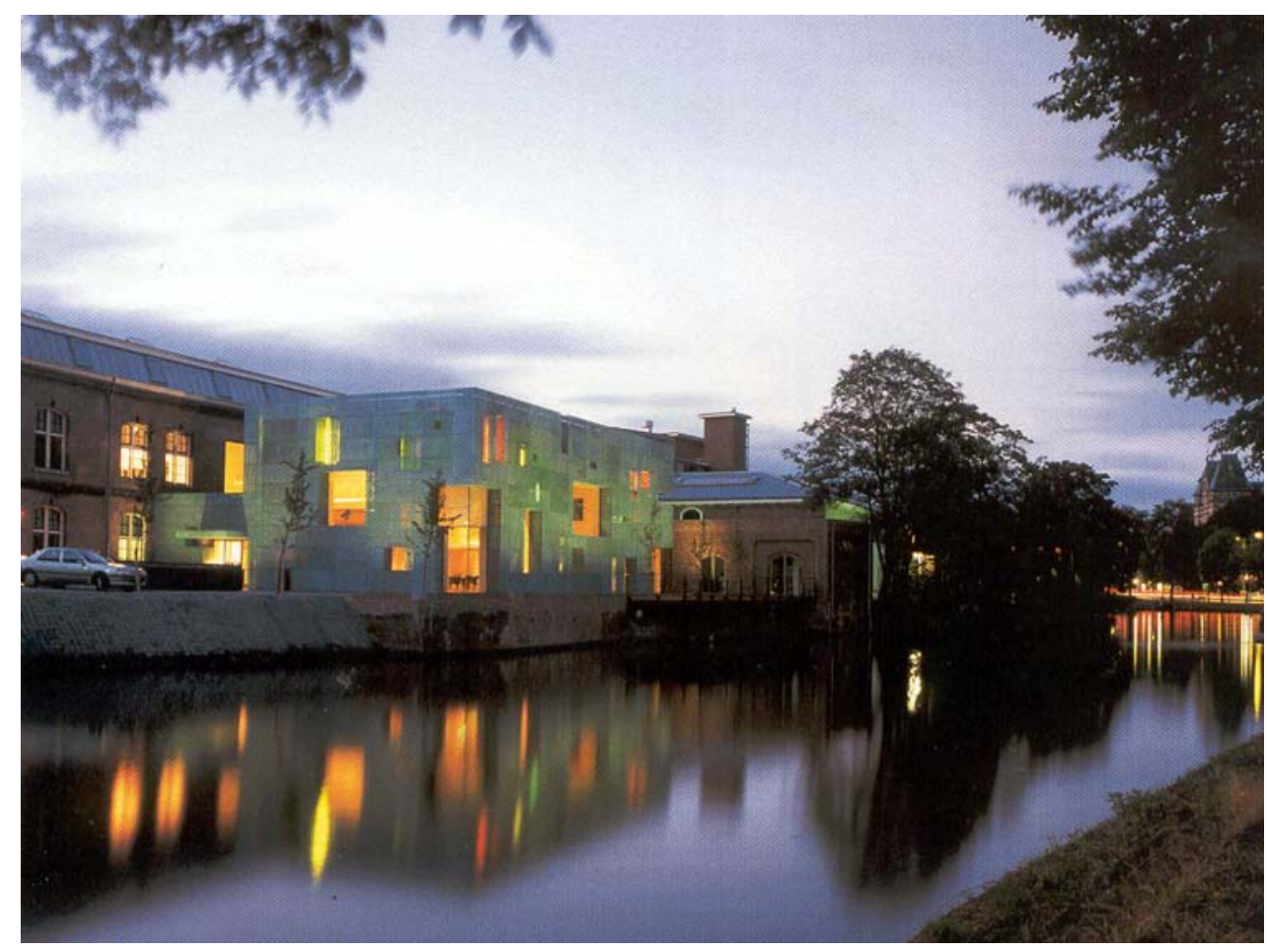

Figure 4.58. Color reflections on the De Single Canal: Sarphatistraat Offices, Amsterdam, 1996-2000.

${ }^{246}$ Op. cit. Holl, S., "Pre-theoretical ground," 1993, p .21. 


\section{CHAPTER 5}

\section{CONCLUSION}

"Phenomenology is the study of essences... a philosophy which puts essences back into existence..."247

The main objective of the thesis was examining the philosophical depth of Steven Holl's architecture in relation to the phenomenology of Maurice Merleau-Ponty. As MerleauPonty searches for "re-achieving a direct and primitive contact with the world" through the realm of perception, behind Holl's phenomenological approach to architecture lies a search for vitalizing essences through the realm of architectural perception intertwined within the human experience of space, material and light. The architect focuses on phenomenology in architecture in order to "put essences into experience." 248

Steven Holl puts forward a specific approach to architecture that develops around an interpretation of the phenomenological philosophy and its translation into the realm of architecture. Particularly, the phenomenological philosophy of Maurice Merleau-Ponty has been influential in Holl's understanding of architecture.

In Holl's architecture, his concern with philosophy leads him to develop a particular, strategic, poetic practice of architecture with an experiential intensity. He stresses on the term of "operational philosophy" that demonstrates the use of philosophy in both the conceptual and phenomenal aspects of his work. ${ }^{249}$ His conceptual approach extends to

\footnotetext{
${ }^{247}$ Op. cit. Merleau-Ponty, M., 1962 (first published in 1945), p. vii.

${ }^{248}$ Op. cit. Holl, S., 2000, p.68.

${ }^{249}$ Op. cit. Holl. S., in Zaero Polo, A., 2003, p. 15.
} 
an experimental search in phenomenal qualities of architecture, wherein the perception of space, time, material and light is tested. Phenomenology constitutes the fundamental ground of his thinking on architecture and making of buildings. What Holl defines as "the intertwining of idea and phenomena," is a unified process: for him, conceptualizing on architecture cannot be detached from an awareness of the phenomena of architecture, through which architecture with intellectual and experiential depth can be created.

While a philosophical depth can be observed in Holl's architectural discourse, the way he makes architecture and his buildings exhibit this philosophical depth. Therefore, it can be concluded that there exists an overall phenomenological framework underlining Steven Holl's architecture. This makes, indeed, the consistency of his work throughout all processes of his architectural creation; the consistency of Holl's work resides in his phenomenological understanding of architecture and the way this extends into his articulation of spaces and forms.

Steven Holl's architecture is phenomenological, intuitive, poetic and experimental. For the architect the world is a phenomenal field of varied colors, odors, textures, and sounds, perceptually connected to human being's existence. In this field of phenomena, experiences provide an unmediated communication between the body and the world, or between the architect and his environment. It is at this point that Holl relates architecture to phenomenology; for him architecture has the potential to intensify the quality of human life by creating spaces that meet humans' not only physical, but also emotional and spiritual demands. Architecture offers the ground we become connected to the world.

Correspondingly, the presence of body gains significance in Holl's architecture. The body-subject having experiences and insights is also the subject of architectural experiences. Thus, for Holl the body becomes "a living spatial measure" in architecture. 250 The sequential dynamic perceptions of moving body in space, which he defines through "parallax," are interpreted as a design tool in his articulation of spaces.

${ }^{250}$ Op. cit. Holl, S., 2000, p. 38. 
In Holl's work, Merleau-Ponty's phenomenological concept of the situatedness of the body-subject into the world is illustrated in his manifesto of "anchoring". Merleau-Ponty suggests that the body-subject inhabits space and time in which a specific situation is established. Similarly, Holl states that architecture is "bound" to a specific situation. ${ }^{251}$ He looks for an intrinsic relation of geography, culture, history, and time to architecture. The particularity of the situation provides the architect with a specific organizing idea for each project, offering the possibility of different starting points for architectural design.

The "anchoring" of architecture into the site and situation becomes a conceptual and experiential ground where Holl searches for the meaning particular to each situation. This meaning emerges through the interpretation of the intrinsic dynamics of a situation. Meaning in architecture cannot be conveyed with another medium other than the experiential potential of a built form; meaning is conceived when a building is experienced. Therefore, what is fundamental for the architect is not the capability of architecture of expressing a distinct meaning, but rather the possibility of infinite meanings generated within the context of subjective experiences of viewers.

Holl's study of architecture extends from the idea, as the conceptual base of the architectural design, to phenomenal aspects of architecture, the material and spatial experiences, feeling of texture, light and shadow effects. He looks for the field of architectural experiences, how a built form is perceived, what is sensed in touching the texture of a wall or seeing the light reflections on a surface. Accordingly, Holl's emphasis on hapticity and its psychological dimension in the experience of architecture are the fundamental means through which the phenomenological content of his work can be designated.

There exists an intuitive approach in Holl's architecture. Intuition in architecture depends on the subjectivity of the architect that cannot be dissociated either from his/her lived experiences, or from cultural and historical associations. Through an intuitively

${ }^{251}$ Op. cit. Holl, 1989, p. 9. 
developed practice, insights and sensations of the architect are made manifest. Intuition lets the architect to experiment his/her subjective potential in architectural creation.

The poetic content of Holl's architecture generates from the phenomenal qualities of his work, his use of light, materials, and colors, achieving an artistic sense of depth. However, for the architect there is a deeper meaning signified through the phenomena of architecture; the poetic sense of life. For Holl, the significance of architecture resides in its power to form a bridge between fields of experiences and the meaning of life. Through experiencing architecture, a poetic and spiritual idea of life is made manifest. Accordingly, Holl considers that, fusing with poetry of space, material and light, architecture "holds the potential to change the way we live." 252

In his phenomenological arguments, Merleau-Ponty considers the field of experiences as designating variation, indeterminacy and ambiguity. For him, phenomenology is a process of inquiry that can never be completed; there are no certainties, no absolute truths, but a search for coming possibilities in phenomenology. Therefore, in aiming to understand the indeterminate nature of human existence, ambiguity becomes the fundamental ground that the philosopher starts from.

Steven Holl states:

“Allowing different possibilities in architecture requires opening up thought, ... working with doubt. To doubt the validity of our ingrained opinions, ideals and views that we so hotly defend takes courage and endurance. What is our central paradox? A joy in doubt in the deepest sense of being." 253

Steven Holl's concern for the critical philosophy of Merleau-Ponty leads him to an openended field of inquiry in architecture. The "pre-theoretical ground," as he calls it, appoints such a flexible research area varying from physical, cultural, historical references of site to time or program. He begins with a pre-theoretical ground out of which the design concept is crystallized. This pre-theoretical ground enables the architect to achieve various starting points for the architectural conception.

${ }^{252}$ Op. cit. Holl, S., 1993, “Dwellings", p. 43. 
Opening towards a phenomenological perspective, Holl develops particular strategies for each project. He works on each project as a unique field of research where the specific factors of a situation, site, culture, history, time or program are re-interpreted. This re-interpretation leads to achieve particular ideas and concepts for architectural creation. This is a strategic approach through which a critical attitude is presupposed. In order to achieve particular ideas and concepts, he has to be critical against what is definite or pre-determined. Holl tends to challenge the definite in order to reach the particular. To be experimental gives the architect the opportunity to project his work to "the-not-yet-worked-over," while resisting standardized or repetitive practices. ${ }^{254}$ Developing strategies leads to new possibilities for architecture, the departure point of which is the particularity of situation. This strategic approach cannot be restricted within methodological principles. To achieve a "limited concept" in re-interpreting the particularity of situation is a strategy ever changing in each project. Each architectural design evolves within an experimental process that leads to the articulation of spaces and forms. A method, on the other hand, designates a definite classification of practices that leads to pre-determined results. In Holl's work, in spite of the phenomenological consistency of his approach, it is not possible to predict the final product. He avoids formulating a methodology for architecture, but rather, develops strategies. Consequently, it is proper to mention that the architectural approach that Steven Holl puts forward is strategic, and not methodological. Therefore, it is not possible to categorize his works with any architectural style; Holl does not create, indeed, a style, but rather puts forward a non-stylistic position in the realm of architecture.

The conceptual discourse of Holl, which is written in a poetic way in his numerous writings, signifies a process of conceptualizing within a phenomenological perspective. As he states, to write on architecture becomes the way "the silent intensities of architecture" are made manifest through words. ${ }^{255} \mathrm{He}$ introduces, indeed, an architectural philosophy elaborated on a particular understanding of phenomenology.

${ }^{253}$ Op. cit. Holl, S., 2000, p. 174.

${ }^{254}$ Op. cit. Holl, S., 1998 (first published in 1996), p. 16.

${ }^{255}$ Op. cit. Holl S., 2003, "Questions of Perception”, p.89. 
In each project, he explains the concept of his architectural design. These explanations involve the ideas that help him in achieving a particular concept to develop the project. However, the verbal explanation of the concept could sometimes lead to literal expressions, weakening the conceptual depth of his work. Steven Holl tends to write narratives where a metaphoric signification between the concept and architectural work is brought forth. Narrative writing could make the architectural expression literal. An attempt to explain the abstract poetic qualities in architectural experience, the sense of space, material and light effects or the tectonic aesthetic through words, can be inadequate in exhibiting both the philosophical and poetic depth of his architecture. Moreover, a search for one-to-one geometric correspondence between the stated concept and architectural form may sometimes lead to a naïve simulation of the verbal reference. In some of his projects, the acting of concept as an image making tool and the material, spatial and geometric embodiment of that image lead the architectural work to exhibit a literal expression.

In the light of the research that was conducted for this thesis it can be concluded that Steven Holl's architecture reveals its significance through the philosophical depth it points out. His focus on phenomenology opens up new horizons for Steven Holl both in theory and praxis of architecture. By fusing the realm of ideas with the experience of phenomena, he probes phenomenological dimensions in architecture. Through the spatial, material and phenomenal qualities of architecture, he searches for the emotive and poetic fields of the experience of architecture. In other words, Steven Holl puts forward a search for synthesizing the intellect with feelings. Therefore, he begins with the understanding of an architectural outlook on human life, which demonstrates, indeed, the philosophical depth of his architecture. As he states:

"For me, the importance of an architect's work does not depend on the skill in developing and contemplating the work itself, but on the potential which the projects interact and have presence beyond the purely architectonic presence." 256

${ }^{256}$ Op. cit. Holl, S., in Zaero Polo, A., 2003, p.30. 


\section{BIBLIOGRAPHY}

Bachelard, G., 1969, Poetics of Space, Boston: Beacon Press.

Bergson, H., Time and Free Will: An essay on the Immediate Data of Consciousness, [Internet, WWW], ADRESS:

http://spartan.ac.brocku.ca/ lward/Bergson/berg02 toc.html [Accessed: 29 April 2004].

Bognar, B., November/December 1992, "Anywhere In Japan, An International Symposium on Space, Site, Place and Architecture," Architectural Design vol. 62 no.11/12, pp. 70-72.

Boumen, O. and Toorn van R., 1994, "On the Work of Steven Holl: Under, In, On and Over the Earth," The Invisible in Architecture, London: Academy Editions, Berlin: Ernst\&Sohn, pp.92-97.

Cevizci, A. (ed.), 2002, Felsefe Sözlüğ̈̈ (The Dictionary of Philosophy), İstanbul: Paradigma Yayıncılık.

Chevalier, J., 1970 (first published in 1928) Henry Bergson, New York: Books for Libraries Press.

Edwards P. (ed.), 1967, The Encyclopedia of Philosophy volume 1 and 2,New York: Colliar Macmillan Publishers.

Frampton, K., 1989, "Towards a Critical Regionalism: Six Points for an Architecture of Resistance," The Anti-Aesthetic. Essays in Post-Modern Culture, H. Foster (ed.), Port Townsend: Bay Press, pp. 16-30.

Frampton, K., 2002, Steven Holl Architect, Milano: Electa Architecture.

Frampton, K., 2003, "The Work of Steven Holl: 1980-1996 A Retrospective Prospect," El croquis (revised and extended edition, including issues 78, 93, 108), Mexico: Arquitectos Publishing, pp. 534-541. 
Güzer, A., 1995, “Modernizm'in Yerellikle Uzlaşma Arayıșı" (Modernism's Search for Compromise with Locality: Holl.), Arredamento Dekorasyon vol.5 no.70, pp. 72-76.

Hammond, M., Howarth, J., Keat, R.N. (eds.), 1991, Understanding Phenomenology, Cambridge, Massachusetts: Basil Blackwell.

Heidegger, M., 1996 (first published in 1951), "Building, Dwelling and Thinking," Rethinking Architecture: A Reader in Cultural Theory, Neil Leach (ed.), London: Routledge, pp. 100-109.

Holl, S., 1984, "Teeter-Totter Principles," Perspecta, The Yale Architectural Journal no.21, Cambridge, Mass.: The MIT Press, pp.32-51.

Holl, S., 1989, Anchoring, New York: Princeton Architectural Press.

Holl, S., 1993, "Pre-theoretical Ground," The Steven Holl Catalogue, Zurich: Artemis and ArcenReve Centre d'Architecture, pp. 21-29.

Holl, S., 1993, "Dwellings," The Steven Holl Catalogue, Zurich: Artemis and arc en reve centre d'architecture, p.43.

Holl, S., 1993, "The Haptic Realm” in The Steven Holl Catalogue, Zurich: Artemis and ArcenReve Centre d'Architecture, p.31.

Holl, S., 1998 (first published in 1996), Intertwining, New York: Princeton Architectural Press.

Holl, S., 2000, Parallax, New York: Princeton Architectural Press.

Holl, S., 2003, "Edge of a City," El Croquis (revised and extended edition), Mexico: Arquitectos Publishing, pp. $72-77$.

Holl, S., 2003, "Within the City," El croquis (revised and extended edition), Mexico: Arquitectos Publishing, pp.78-87.

Holl, S., "Phenomenology," [Internet, WWW], ADRESS:

http://www.arch.uiuc.edu/thesisstudio/tgs/history-3.htm [Accessed: 30 June 2003]. 
Holl, S., 2003, "Questions of Perception," El Croquis, revised and extended edition), Mexico: Arquitectos Publishing, pp.88-89.

Holl, S., "Architecture=Integral Phenomena," [Internet, WWW], ADRESS: http://www.arch.columbia.edu/gsap/19006/ [Accessed: 19 December 2003].

Honderich T. (ed.), 1995, The Oxford Companion to Philosophy, Oxford: Oxford University Press.

Lacey A. R. (ed.), 1986, A Dictionary of Philosophy, London: Routledge Press.

Kendir, E. (trans.), October 2003, "Fikir ve Olgu, Steven Holl Mimarlı̆̆ının Özeti" (Idea and Phenomena, The Summary of Steven Holl's architecture), XXI vol.17, pp. 4447.

Kipnis, J., 2003, “A Conversation with Steven Holl,” El Croquis, revised and extended edition (first published in El Croquis issue 93 November/December 1998), Mexico: Arquitectos Publishing, pp. 36-47.

Langer, M. M., 1989, Merleau-Ponty's Phenomenology of Perception, A Guide and Commentary, London: Macmillan Press.

Lauer, Q., 1958, Phenomenology: Its Genesis and Prospects, New York: Harper and Row Publishers.

Le Cuyer, A., July 1997, "Congregation of Light" Architectural Review volume 202 issue 5, pp.26-32.

Macann, C., 1993, Four Phenomenological Philosophers: Husserl, Heidegger, Sartre, Merleau-Ponty, London, New York: Routledge Publishing.

Moneo, R., May 1998, “The Murmur of the Site” (Yerin Fisiltıs1) trans. by Dr. Emel Aközer, ANY Seçmeler, ed. Haluk Pamir, Ankara: The Association of Architects Publishing, p. 2-9. 
Merleau-Ponty, M., 1962 (first published in 1945), Phenomenology of Perception, trans. by Colin Smith, London: Routledge and Kegan.

Merleau-Ponty, M., 1967, "The Primacy of Perception and Its Philosophical Consequences," Readings in Existential Phenomenology, Lawrence, N., O'Connor, D. (eds.), New Jersey: Prentice-Hall Press.

Merleau-Ponty, M., 1968, The Visible and the Invisible, Claude Lefort and Alphonso Lingis (eds.), translated by Hazel E. Barnes, USA: Northwestern University Press.

Migayrou, F., 1993, "Steven Holl: Proceedings of an Elementary Architecture." The Steven Holl Catalogue, Zurich: Artemis and ArcenReve Centre d'Architecture, pp.13-18.

Norbeg-Schulz, C., 1971, Existence, Space and Architecture, New York: Praeger Publishers.

Norbeg-Schulz, C., 1979, Genius Loci, Towards a

Phenomenology of Architecture, New York: Rizolli International Publications.

Norberg-Schulz, C., 1985, The Concept of Dwelling, New York: Rizolli International Publications.

Norten, E., 1997, “Immaterial Architecture,” Anybody, Cynthia Davidson (ed.), New York: Anyone Corporation, pp. 190-195.

O’Neill, M. E., September 2001, “Corporeal Experience: A Haptic Way of Knowing," Journal of Architectural Education vol. 85 issue 1, pp. 3-12.

Pallasmaa, J., 2003 (first published in El croquis issue 108 November/December, 2001), "Thought, Matter and Experience," El croquis (revised and extended edition), Mexico: Arquitectos Publishing, pp.48-69.

Pérez-Gomez, A., 1998 (first published in 1996), "Introduction," Intertwining, New York: Princeton Architectural Press, pp. 9-10. 
Pérez-Gomez, A., 2003, "The Architecture of Steven Holl: In Search of a Poetry of Specifics" in El croquis, 2003 (revised and extended edition, including issues 78, 93, 108), Mexico: Arquitectos Publishing, pp. 542-551.

Perez-Gomez, A., 1983, Architecture and the Crisis of Modern Science, Cambridge, Massachusetts: The MIT Press.

Rohmann C. (ed.), 1999, A World of Ideas, A Dictionary of Important Theories, Concepts, Beliefs and Thinkers, New York: Ballantine Books.ü

Safran,Yehuda E., 2002, "Steven Holl: Idea and Method," Idea and Phenomena, Architekturzentrum Wien (ed.), Switzerland: Lars Müller Publishers, pp.73-83.

Safran, Yehuda E., April 2003, "Holl's hall of residence for MIT is his most significance building yet...” Domus vol. 858, pp. 40-61.

Savaş, A., May 1995, “El Yordamıyla Mimarlık: Paralaks, bilinç, içgüdü ve Steven Holl" (Intuitive Architecture: Parallax, consciousness, intuition and Steven Holl" in Arredamento Dekorasyon vol.5 no.70, pp. 76-77.

Şentürer, A., 2002, “Mimarlıkta Felsefe Nerede Duruyor?” Mimarlık ve Felsefe, Şentürer, A., Ural, Ş., Atasoy, A. (eds.), İstanbul: Yapı Endüstri Merkezi Yayınları, pp. 132-145.

"Steven Holl: Fikir ve Yöntem" (Steven Holl: Idea and Phenomena), Tasarım vol. 142 issue 6, 2004, pp. 74-129.

Tanyeli, U., February 2002, "Steven Holl. Kavramsal Mimarlığın Yeni Ürünleri." (Steven Holl. New Products of Conceptual Architecture), Arredamento Dekorasyon vol.2, pp.40-54.

Till, J., Nov. /Dec 1996, “Architecture in Space, Time,” Architectural Design vol. 66 no.11/12, pp. 9-13. 
Zaera Polo, A., 2003 (first published in El croquis issue 78 January/February 1996), "A Conversation with Steven Holl," El croquis (revised and extended edition) Mexico: Arquitectos Publishing, pp. 10-35. 